\title{
Recent Advances in Functional Polymer Materials for Energy, Water, and Biomedical Applications: A Review
}

\author{
Yassine EL-Ghoul ${ }^{1,2, * \mathbb{D}}$, Fahad M. Alminderej ${ }^{1, *}$, Fehaid M. Alsubaie ${ }^{3, *}$, Radwan Alrasheed ${ }^{4}$ \\ and Norah H. Almousa ${ }^{3}$ \\ 1 Department of Chemistry, College of Science, Qassim University, King Abdulaziz Rd, P.O. Box 1162, \\ Buraidah 51452, Saudi Arabia \\ 2 Textile Engineering Laboratory, University of Monastir, Monastir 5019, Tunisia \\ 3 National Center for Chemical Catalysis Technology, King Abdulaziz City for Science and Technology, \\ P.O. Box 6086, Riyadh 11442, Saudi Arabia; nalmousa@kacst.edu.sa \\ 4 National Center for Desalination \& Water Treatment Technology, King Abdulaziz City for Science and \\ Technology, P.O. Box 6086, Riyadh 11442, Saudi Arabia; ralrasheed@kacst.edu.sa \\ * Correspondence: y.elghoul@qu.edu.sa (Y.E.-G.); f.alminderej@qu.edu.sa (F.M.A.); \\ falsubaie@kacst.edu.sa (F.M.A.)
}

Citation: EL-Ghoul, Y.; Alminderej, F.M.; Alsubaie, F.M.; Alrasheed, R.; Almousa, N.H. Recent Advances in Functional Polymer Materials for Energy, Water, and Biomedical Applications: A Review. Polymers 2021, 13, 4327. https://doi.org/ $10.3390 /$ polym 13244327

Academic Editor: Zhenhao Xi

Received: 18 November 2021 Accepted: 6 December 2021 Published: 10 December 2021

Publisher's Note: MDPI stays neutral with regard to jurisdictional claims in published maps and institutional affiliations.

Copyright: (c) 2021 by the authors. Licensee MDPI, Basel, Switzerland. This article is an open access article distributed under the terms and conditions of the Creative Commons Attribution (CC BY) license (https:// creativecommons.org/licenses/by/ $4.0 /)$.

\begin{abstract}
Academic research regarding polymeric materials has been of great interest. Likewise, polymer industries are considered as the most familiar petrochemical industries. Despite the valuable and continuous advancements in various polymeric material technologies over the last century, many varieties and advances related to the field of polymer science and engineering still promise a great potential for exciting new applications. Research, development, and industrial support have been the key factors behind the great progress in the field of polymer applications. This work provides insight into the recent energy applications of polymers, including energy storage and production. The study of polymeric materials in the field of enhanced oil recovery and water treatment technologies will be presented and evaluated. In addition, in this review, we wish to emphasize the great importance of various functional polymers as effective adsorbents of organic pollutants from industrial wastewater. Furthermore, recent advances in biomedical applications are reviewed and discussed.
\end{abstract}

Keywords: polymer/functional polymer applications; batteries; solar cells; water treatment; enhanced oil recovery; biomedical

\section{Introduction}

An increasing interest in the development of functional materials has led to the appearance of so-called smart polymers, which have demonstrated their practical performance in a wide range of application fields. These technical polymers are successfully gaining a growing number of recipients in the field of renewable energies, medical diagnostics, water treatment, pollution control, environmental protection, and food safety, thanks to their high sensitivity, diversity, specificity, and capacity for analysis in real time [1-7]. Some polymers are active and functional in nature, but others need to be modified to improve their impact and functionality. Several recent methods and techniques have been developed for the functionalization of the surfaces of synthetic and natural polymers [8-12]. Indeed, the terminal groups of the surface of a polymer could be linked or modified by reactive functional groups. Secondly, different molecules, oligomers, or active/bioactive polymers can be grafted to the surface, thus offering new desired properties which match the requirements of a targeted use [13-17]. Because of their inert character, polymeric surfaces need to be pre-activated before proceeding to their functionalization. This pretreatment will give them an active surface for the immobilization of the various active agents. This surface activation could be performed chemically by grafting different active functions and branches, or physically, via different techniques, such as plasma treatment, 
laser treatment, UV irradiation, ozonolysis, electron beams, etc. [18-24]. Functionalization of polymeric surfaces is generally provided chemically either via covalent bonds and low energy interactions [25-27], or by non-covalent physical attraction, such as the adsorption of pollutants [28,29], antibacterial biomaterials [30-32], and drug delivery systems [33-35]. Covalent chemical functionalization remains the most interesting and the most advantageous. Indeed, it ensures a good durability of the active ingredients and a good stability of the active principle before and after its applied action. The chemical grafting of polyfunctional molecules or macromolecules and the functionalization via spacer compounds increases the efficiency of the polymeric surfaces by conferring them more active and spaced functions, therefore making them more effective and relevant.

Below is an overview of recent advances in polymers and functional polymeric materials and their exploration in the development of various applicative fields and industrial equipment (Figure 1).

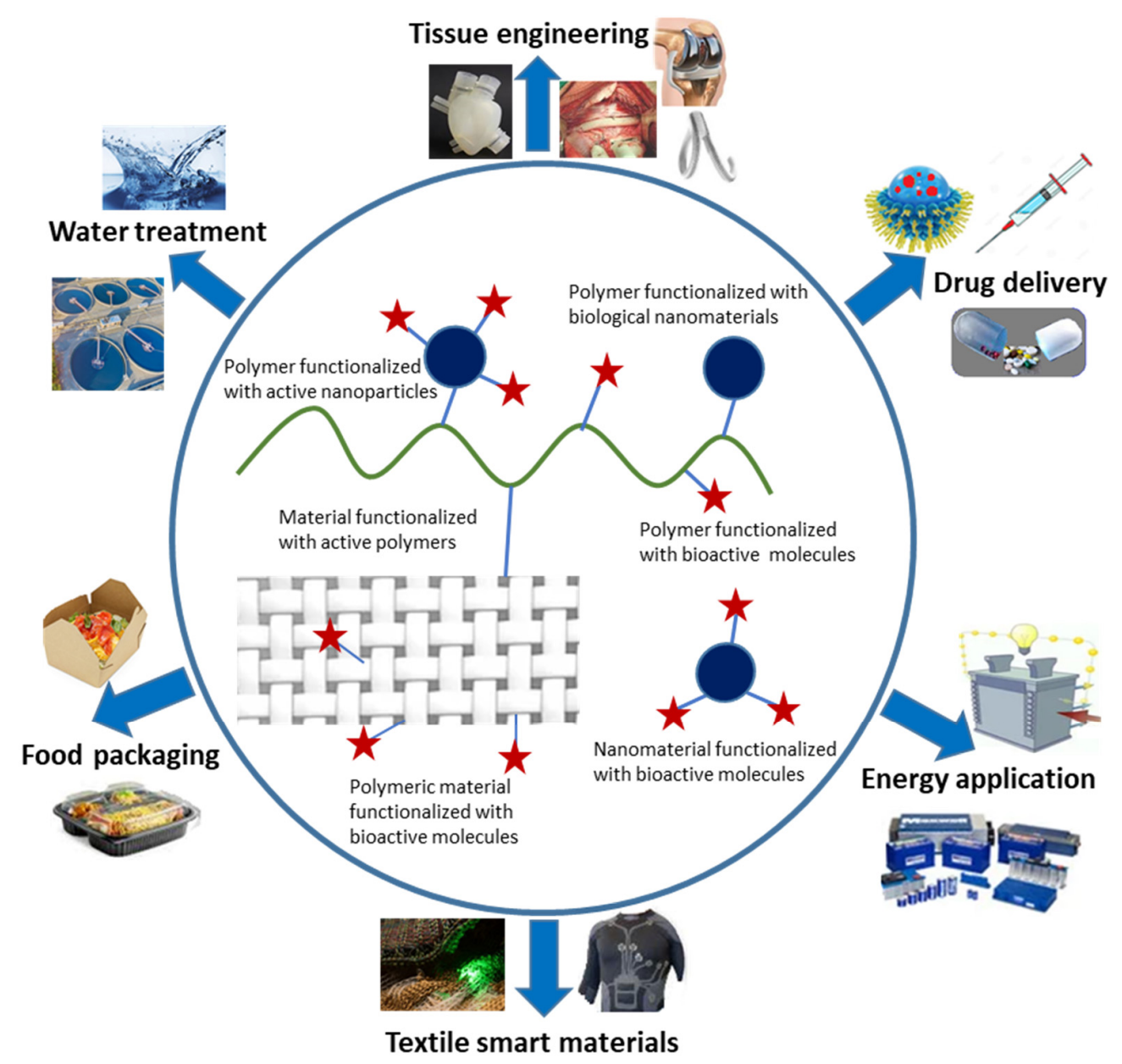

Figure 1. Applicative fields related to functional polymeric materials.

\section{Energy Applications of Polymers}

Currently, energy and sustainable energy have increasingly gained a leading position as the most important global concerns in view of the increased depletion of fossil fuels. Material and nanomaterial-based polymers and their composites are investigated in many various applications related to energy storage and production (Figure 2), including batteries, solar cells, super-capacitors, domestic tools, vehicles, fuel cells, biomedical equipment, and surgical appliances [36-44]. Conducting polymers are organic polymers that can conduct electricity, and they also may be used as semiconductors. Generally, the class of polymers known as characteristically conducting polymers, or electroactive conjugated polymers, were developed about 20 years ago, and their ability to conduct electricity is 
due to the occurrence of delocalized molecular orbitals. In addition to their conduction properties, they also exhibit interesting characteristics, such as electronic, magnetic, wetting, optical, mechanical, and microwave absorption properties. Conducting polymers (CPs) have received a lot of attention due to their economic importance, good environmental stability, and electrical conductivity, as well as their useful mechanical, optical, and electronic properties. Generally, conducting polymers have different nanostructures with a higher specific capacitance and may constitute an alternative in the development of new-generation energy storage devices [45-50]. There are many types of conducting polymers that have the ability to conduct electrical current. These conducting polymers generally are classified into three principal groups: ionic conducting polymers [51-53], intrinsically conducting polymers (ICPs), which also are known as synthetic metals [54-56] and conducting polymer composites [57-60].

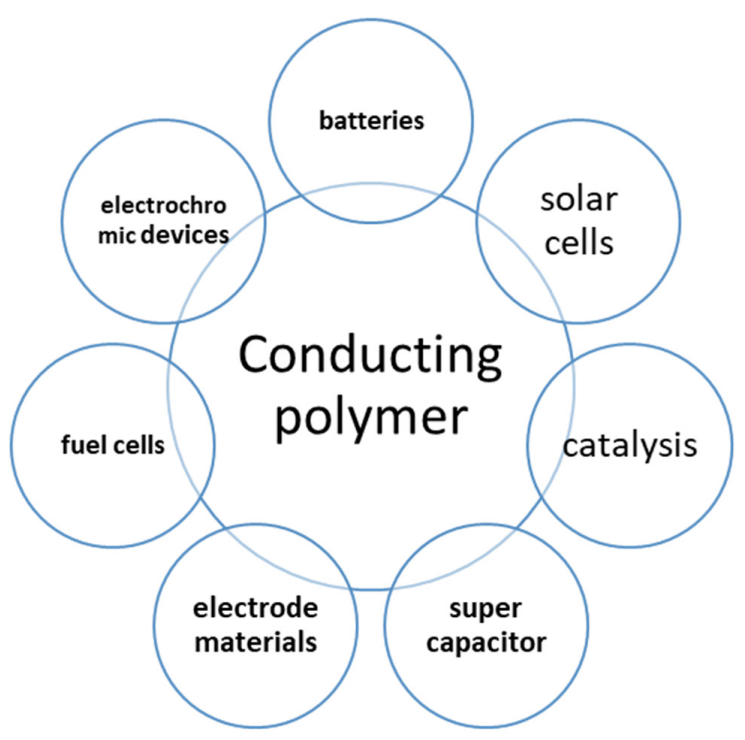

Figure 2. General applications of conducting polymers.

This distinctive type of polymer has been used in many important applications in the fields of the production and storage of energy, such as in energy assembly, energy storage, solar cells, batteries, photocatalysis materials, electrode materials, electrochromic devices, dye-sensitized electric cells, light emitting and sensing devices, and perovskite electric cells. They also have been used in other important applications, including as p-type conducting parts in thermoelectric generators, as well as being the polymer composites that are used in thermoelectric generators, piezoelectric materials, triboelectric generators, and super capacitors [61-74]. Figure 2 shows the general applications of these conducting polymers.

Polyacetylene, polypyrrole, polythiophene, and polyaniline are examples of intrinsically conducting polymer ICPs. Among the existing conducting polymers, polyaniline has attracted considerably more attention than other types of polymers in recent years because of its superior properties, which include its ease of synthesis, unvarying conduction mechanism, and superior resistance to the effects of oxygen and water [75-77].

Recently, new types of conducting polymers have appeared and have proven to be effective in several fields and applications.

\subsection{Batteries as an Energy Storage Application of Polymers}

Many organic polymers can retain and store energy when they charged with electric current, and this energy can be used when it is needed, making it a general area for continuous and sustainable investment in both the short term and the long term. Currently, the most common battery systems are based on the Li-ion technology. This technology was proposed by M. S. Whittingham in 1976, and it was commercialized by SONY in 1990. Additionally, in the 1980s, conducting polymers were extolled as promising materials for 
the next generation of environmentally benign and efficient batteries. In the late 1980s, Bridgestone-Seiko and VARTA/BASF initiated their sales of commercial batteries that were based on polypyrrole and polyaniline, respectively [78]. One of the most intensively studied conjugated polymers for energy storage applications is polypyrrole, which also was used as an anode material to manufacture an aqueous Li-ion battery in conjunction with a $\mathrm{LiCoO}_{2}$ cathode $[79,80]$. Polythiophene has been of interest to electrochemists for decades. The first battery with polythiophene as an active material was produced and described in 1983. Recently, poly(3'-styryl-4, $4^{\prime \prime}$-didecyloxyterthiophene), with a maximum capacity of $45 \mathrm{Ah} \mathrm{kg}^{-1}$, and poly (4,4"-didecyloxyterthiophene), with a maximum capacity of $95 \mathrm{Ah} \mathrm{kg}^{-1}$, were used as anode materials in combination with a polypyrrole cathode. Another type of polymer that was used in an earlier period consisted of polyaniline (PANI) pellet electrodes with different redox states. In addition, polyacetylene usage for anodes and cathodes and a PEO-based electrolyte were presented in 1981. Also, as recently shown by Zhu et al. [81], the bipolar active material known as poly(para-phenylene) can act as both a cathode and an anode. Many organic polymers can retain and store energy when charged with electric current, and the energy can be used when needed, making it a general area for continuous and sustainable investment in the short and long term. The ultrafast high energy density, long-term stability, and charge-discharge behavior are unique features of supercapacitors, which have attracted considerable attention recently. Different supercapacitors have emerged as efficient energy storage devices, showing wide applications in several fields, including electric vehicles and continuously automatic production power supplies, etc. [82-86]. These supercapacitors exhibit a higher specific power when compared to lithium-ion batteries. The electrodes of these supercapacitors are materials that are based on metal oxides but mainly on conductive polymers [87-90]. These conductive polymers have shown an excellent specific capacity and their low cyclic stability has been lately overstated by the investigation of nanocomposites which was based on conducting polymers [91-93].

\subsection{Solar and Fuel Cells as an Energy Production Application of Polymers}

Natural resources will be exploited for a clean environment and a good life in different countries. The importance of solar cells in the production of clean and sustainable electric power is attributed to places that government services do not reach or when the production of energy from the sun becomes cheaper than other sources. Silicon solar cells are widely used, but there is considerable research being done with the aim of providing less expensive solar cells, such as polymer solar cells and perovskite solar cells. [94-97].

Polymer solar cells, also known as plastic solar cells, use conjugated polymers as light absorbers, electron donors, electron acceptors, and/or hole transport materials, and these solar cells have been investigated for twenty years. A typical polymer solar cell contains a donor/acceptor bulk-heterojunction, a light-harvesting layer that is sandwiched between the electron and hole extraction layer, then the anode and the cathode. When polymer solar cells were first developed, their structure was similar to a conventional silicon-based solar cell with a planar junction. People believe that this device works as a P-N junction solar cell, based simply on its organic p-type and n-type semiconductor material coatings. At this point, the polymer functions as a photoactive layer for light absorption, charge generation, and transport [98,99].

Nowadays, various electrochemical reactions have been investigated in the direct conversion of chemical energy into electricity, in the context of fuel cells. These fuel cells have recently experienced great progress in their application for the production of electric vehicles [100,101]. Indeed, direct methanol fuel cells (DMFCs) have shown great potential in various energy applications, due to their energy conversion performance, high fuel portability, and eco-friendly aspects [102-104]. Several parameters influencing the efficiency of DMFCs have been reported, and the effects of the electrocatalysts used have been widely studied. These electrocatalysts are mainly conducting polymers, having primarily 1D and 2D nanostructures [105-110]. 


\section{Oil and Gas Applications}

Enhanced oil recovery (EOR), also known as tertiary recovery, is the most commonly used method to extract crude oil from an oil field when it cannot be extracted otherwise [111,112]. EOR can extract 30 to $60 \%$ or more of the oil from a reservoir. Due to the decrease in the discoveries of oil over the past few years, it is believed that enhanced oil recovery technologies will be vitally important, by ensuring the extended use of oil to generate energy. One of the reasons for this is due to the shortage of current oil resources and the difficulty associated with identifying new oil fields. Polymers have an important role in the application of enhanced oil recovery technology, especially surfactant and hydrogel polymers. Surfactant polymers are injected into the reservoir to reduce the interfacial tension between oil and water, which allows recovery of the oil that is trapped by the rocks in the reservoir, thereby increasing the production of oil. A hydrogel polymer is injected into the reservoir to increase the viscosity of the fluid that contains water, making that fluid more difficult to flow than the oil, thereby increasing the production of oil. The most common polymer that is used for this application is one or more of the polyacrylamide group $[113,114]$. A typical polymer flood project involves the mixing and injecting of polymer over an extended period of time until about 30 to $50 \%$ of the pore volume of the reservoir has been injected. The addition of polymer into the reservoir increases the viscosity of water and reduces the relative permeability of the water in the reservoir, thereby increasing the recovery of oil due to the increase in the fractional flow.

Hydrogel polymers have been used for many years to control the mobility of the injected water during enhanced oil recovery applications. These polymers are nonNewtonian (also called pseudoplastic) fluids because their viscosities are a function of the shear rate. They usually are used with surfactants and alkali agents to increase the sweep efficiency of the tertiary recovery floods [115-117]. It is important to select the appropriate polymer for a given area. Thus, the permeability of the reservoir and the viscosity of the oil are used to determine which polymer has the optimum molecular weight. The composition of the rock and the extent of adsorption of the polymer are used to determine the best degree of hydrolysis.

\subsection{Polyacrylamides}

The synthetic polymer used in enhanced oil recovery applications is almost always one of the polyacrylamides. A variety of these products is available from several manufacturers. In general, the performance of a polyacrylamide depends on its molecular weight and its degree of hydrolysis $[113,114,118]$. Partially hydrolyzed polyacrylamide (HPAM) is one of the polyacrylamide group, and it has the shape of a straight chain polymer of acrylamide monomers, some of which have been hydrolyzed. The HPAM is the polymer most often used in enhanced oil recovery applications, due to its relatively low price and good viscosifying properties [119].

\subsection{Xanthan Gum/Biopolymer}

Xanthan gum is a manufactured polysaccharide that is generally referred to as a biopolymer. It is produced by the microbial action of xanthomonascampestris on a substrate of carbohydrate media, with a protein supplement and an inorganic source of nitrogen. It is well known that xanthan gum has an excellent performance in high salinity brine. It is relatively compatible with most surfactants and the other injection fluid additives which are used in tertiary oil recovery formulations. The biopolymer is usually injected along with an effective biocide, to prevent microbial degradation [120]. Recently, a supramolecular system by self-assembly of xanthan gum with anionic or cationic surfactants and $\beta$-cyclodextrin has been developed. This composite polymer system has shown thermal and bio-stability, and greater viscoelasticity in brines, and thus confirmed its potential as a promising tool for enhanced oil recovery applications [121]. 


\subsection{Superabsorbent Polymer Composites for Enhanced Oil Recovery}

Superabsorbent polymer composites are three-dimensionally crosslinked hydrophilic polymers reinforced by clay, and they are capable of swelling and retaining huge volumes of water in this swollen state [122,123]. Superabsorbent polymer composites have been used as plugging agents in some oil fields in China to meet the need of enhanced oil recovery [124]. After operating for a year, in which water flooding was a perpetual problem, the water content in the crude oil increased, and this decreased the oil output. The high water content in crude oil can cause many problems, such as increased corrosion, increased amounts of sand, and the formation of emulsions that must be disposed of. Based on the results of this research, it was concluded that, when compared to the existing polymer, the superabsorbent polymer composite had good mechanical, thermal, and rheological properties. Recently, pH-sensitive poly (acrylamide-co-methylenebisacrylamide-co-acrylic acid) hydrogel microspheres immobilizing silica nanoparticles have been synthesized by reverse suspension polymerization. The prepared hybridized polymeric composite exhibited a significant improvement in the swelling property as a function of the change in $\mathrm{pH}$ and showed a $23 \%$ increase in the oil recovery factor [125]. Even so, additional advanced studies should be done to determine whether these different polymers could be used effectively for enhanced oil recovery [126].

\section{Advances in Biomedical Applications}

The biomedical sector is a very specific field of applications for polymeric materials. Indeed, it exploits, or attempts to exploit, various compounds by controlling their different chemical, physical, and mechanical properties while ensuring an effective therapeutic function towards complex biological systems and phenomena, whose parameterization is almost impossible. For a long time, man has tried to exploit the macromolecular compounds he has invented and developed over the years for various therapeutic purposes. Thus, since the Second World War, the biomedical field, comprising a surgical component involving prosthetic systems, and a pharmacological component, implying drug substances, was a booming scientific and economic sector. Polymers and functionalized polymeric materials are widely studied in many biomedical applications mainly due to their relevant properties, excellent biocompatibility, and the diversity of their technical characteristics. Many polymers and functional polymeric materials have been developed to improve the performance of medical diagnostics through various approaches, including the enhancement of the contrast in imaging technologies and the promotion of molecular recognition in advanced diagnostic assessments. Polymers for diagnostics have attracted the attention of researchers and manufacturers considerably, due to their reliability in offering both simple and rapid diagnostics, as well as in the transport and protection of drugs immobilized in their structures. Vallejos et al. have prepared a polymeric chemosensory membrane-based vinyl copolymer, grafted with 6-methoxyquinoline groups as chloride responsive fluorescent moieties. This sensory material revealed an excellent efficacy for the detection and quantification of chloride in human sweat and has thus shown its promising capacity for the diagnosis of cystic fibrosis [127]. Polydimethylsiloxane (PDMS) was the more investigated material in the preparation of different organ-on-a-chip devices and microphysiological systems (MPSs). PDMS has shown an efficient and versatile performance in various medical applications. However, many deficiencies have lowered its importance, and applicative improvements still remain. Recently, various alternative polymeric materials (Figure 3), including hydrogels, elastomers, glass polymers, resins, paper, thermoplastic polymers, and nanocomposites, were applied as organ-on-a-chip devices and microphysiological systems providing more functionalities, such as enhanced inhibition of absorption, leaching, and auto-fluorescence, as well as affording more capacity for rapid prototyping [128-130]. 


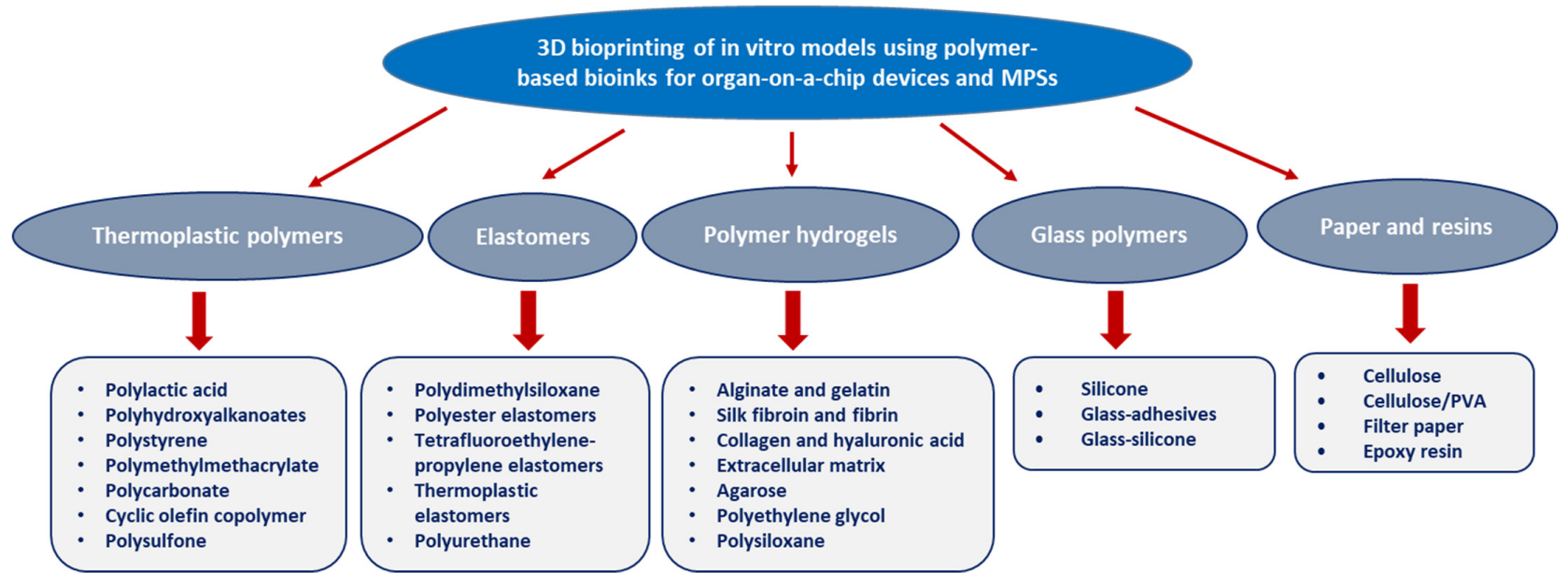

Figure 3. Polymer-based bioinks used for organ-on-a-chip platforms and microphysiological systems (MPSs).

These materials were thus promising in personalized medicine, modeling, drug discovery, in vitro pharmacokinetic/pharmacodynamics, and in the investigation of cellular responses to drugs. Indeed, advances in preparation technologies, such as 3D bioprinting, have led to an effective use of different hydrogel-based devices. Various hydrogel-based natural polymers (alginate, gelatine, silk fibroin, hyaluronic acid, collagen, fibrin, decellularized extracellular matrix, and agarose) and synthetic polymers (mainly polyethylene glycol and polysiloxane) have been used as bioinks in the preparation of different materials for building 3D cell-laden structures by bioprinting technologies. Hydrogels can also be used in complex structures and topographies to better mimic the natural extracellular environment. In a recent study, Gebeyehu et al. [131] prepared a polysaccharide hydrogel ink-based 3D bioprinted tumor model for chemotherapeutic drug screening. The fabricated cell-laden scaffolds using the different bioinks (H4 and H4-RGD) exhibited excellent mechanical properties. Bioinks showed a good printability at relatively low temperatures, and without a UV curing step. Xenograft cells (PDC), derived from 3D printed non-small cell lung cancer (NSCLC) patients, exhibited a relatively rapid spheroid growing and the creation of a tumor microenvironment after 7 days. The half maximal inhibitory concentration (IC50) evaluation revealed a greater resistance of 3D spheroids to docetaxel, doxorubicin, and erlotinib to untamed type triple-negative breast cancer (MDA-MB-231-WT) and pulmonary adenocarcinoma (HCC-827) cells. Different results of the shape fidelity, flow property, biocompatibility, and scaffold stability of the H4-RGD hydrogel system confirmed the ability of this natural bioink polymer to be effective in the fabrication of different 3D cell bioprinting models, as well as in the development of in-vitro tumor microenvironments for the high-throughput screening of diverse anticancer drugs. Lin et al. [132] developed 3D bioprinted proximal vascularized tubule models, featuring adjacent ducts lined with a confluent epithelium and endothelium, continuous in a polymeric permeable ECM. Three-dimensional fabricated kidney tissue ensured the timely quantification of glucose reabsorption and albumin uptake over time. The three-dimensional renal tissue, through the different assessments, could provide a valuable platform for various in vitro investigations of renal function, disease modeling and pharmacology.

Currently, functional polymers and are experiencing a rapid and continuous progress as drug delivery and protein purification systems. Due to their diversity, surface and bulk properties, polymers are the most effective biomaterials applied in drug formulations and in drug delivery devices such as implants [133-135]. Recent drug delivery systems involve dendrimers, micelles, polymeric nanoparticles, liposomes, microcapsules, cell ghosts, and lipoproteins. These advanced polymeric systems provide a promising tool in the improvement of the intrinsic bioavailability, the safe carrying, the controlled release, and the targeting properties via various mechanisms [136]. Dendrimers are water-soluble, highly structured, designed polymer macromolecules. They are widely investigated as 
carriers for anti-tumor drugs [137]. PAMAM (polyamidoamine) dendrimers are being studied as efficient carriers (vectors) in gene therapy [138-140]. They are synthesized in different sizes and shapes, thus providing well-shaped carriers designed with nanometric sizes. These dendrimers can contain various polymeric ligands, such as PEG, allowing the protection of the ingredients and others, ensuring the targeting of the cells via specific bonds to the cellular receptors, those being essentially via the sugars [141,142]. Linear and branched polyethylenimine (PEI) polymers have shown an excellent performance in DNA encapsulation and complex transfection in gene therapy applications [143]. Adamantane or histidine moieties could be grafted to the polyketal (pADK) polymer to obtain stable DNA complexes and by the inclusion of these moieties in cyclodextrin cavities which are linked to PEI polymer [144]. This modified polymer could be linked to a PEG-sugar-carriertargeting polymer to finally obtain an efficient star-shaped vector, applied in gene therapy (Figure 4).

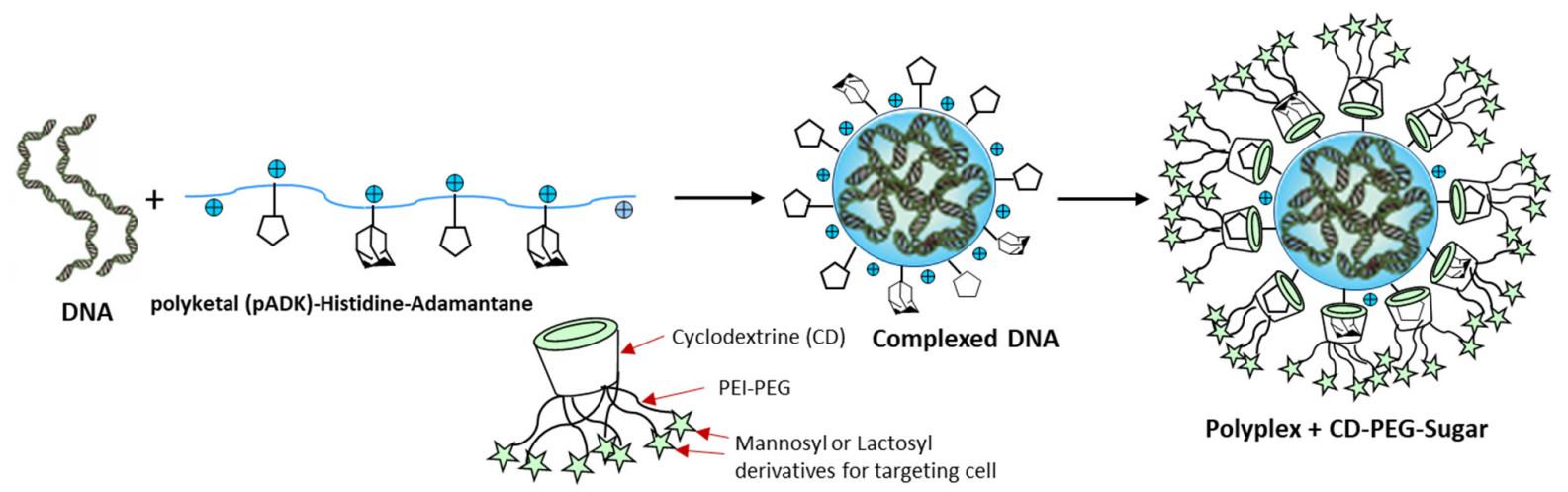

Figure 4. Illustration of smart-shaped polyketal-histidine-adamantane polymer carrier complexing DNA, with a PEG polymer as protective agent and lactose or mannose as cell-targeting molecules, applied in gene therapy.

A novel gene vector, PEG-GO-PEI-FA-based graphene oxide (GO), was synthesized, in which folic acid (FA) can specifically bind to the folate receptor. Well-condensed and stable nanocomplexes of siRNA were obtained, exhibiting a mild cytotoxicity with a high uptake efficiency in ovarian cancer cells [145].

Smart polymers display chemical, physical, or structural changes based on changes in the environmental conditions. In biology applications, stimuli-responsive polymers undergo a change in their intrinsic properties in response to the change in biological conditions [146-155]. The different stimuli can be $\mathrm{pH}$, temperature, pressure, electric or magnetic fields, concentration, light, ionic force, redox potential, etc. [156-166]. During the GI (gastrointestinal) process, the $\mathrm{pH}$ changes, which is taken into consideration in the design of different oral drug delivery systems $[167,168]$. Swollen tissue and cancerous tissue exhibits a significant change in $\mathrm{pH}$. Due to this change in $\mathrm{pH}$, the polymers coating the drugs release their active ingredients. Thanks to this release mechanism, polymers such as the PEI-PEG copolymer release complexed DNA once inside the cell. Similarly, poly (methacrylic acid), linked to the PEG polymer, protects and then releases the proteins that are administered orally. Likewise, polymers which are sensitive to temperature variation, revealing a change in the hydrophilicity/hydrophobicity balance, thus induce a more improved membrane permeation. Among the thermo-responsive polymers, PNIPAAm has been well reported [169-171]. The change in temperature causes it to experience an abrupt phase transition. In fact, this polymer has a typical lower critical solution temperature (LCST), below which it exists in the form of a hydrophilic coil; exceeding this temperature, its chain structure suddenly turns into a hydrophobic globule. Recently, a wide range of functional and well-designed polymers were investigated as effective and novel nanocarriers for drug delivery systems in the loading of various natural active metabolites. Besides, lignin nanoparticles (LNPs) were used as nanocarriers of curcumin ingredients, applied as a novel oral drug delivery system. In vitro and in vivo results of their ingredient stability, 
bioavailability, cell viability, cellular uptake, and intestinal permeation were efficient and promising [172]. By increasing drug solubilization in the stomach and reducing first-pass metabolism via drug diffusion through the lymphatic to the circulatory system, lipids, loading natural ingredients, thereby promote the penetration of these drugs into the digestive tract [173]. Currently, lipid nanoparticles are widely investigated as efficient nanocarriers in different drug delivery applications (Figure 5). Among those lipids used as drug nanocarriers, we find the solid lipid nanoparticle (SLN) which is a colloidal drug nanocarrier, and is generally treated with an emulsifier to improve the stabilization of the prepared dispersion comprising the solid lipid that is melted in water [174]. The SLN, loaded with puerarin, is the most studied complexed nanocarrier. The in vivo assessments on rats revealed its good bioavailability, rapid absorption, and increased tissue concentrations in the heart and brain as targeted organs $[175,176]$. Zhang et al. developed a new triptolide-loaded SLN nanocarrier system. This organic nanocarrier showed solubility and bioavailability improvements as well as excellent antioxidant and anti-inflammatory effects via the reduction recorded in glutathione (GSH) and myeloperoxidase (MPO) metabolism [177].

Nanostructured lipid carrier (NLC) is a second-generation lipid nano-sized particle, comprising a blend of various solid and liquid lipids [178-181]. Thymoquinone (from Nigella sativa)-loaded NLC nanocarriers showed an improved bioavailability and oral delivery behavior in $4 \mathrm{~T} 1$ bearing Balb/C mice. Furthermore, measurements of liver biomarkers and anti-oxidant capacity revealed significant enhancements [182]. Currently, different innovative NLC lipids have been investigated as effective nanocarriers for anticancer purposes. Indeed, citral (from Cymbopogon citratus) [183] and zerumbone (from Zingiber zerumbet L. Smith) [184], as a valuable drug, considerably increased the antitumor activity in lymphoblastic leukemia and breast tumor cells after in vitro and in vivo assessments.

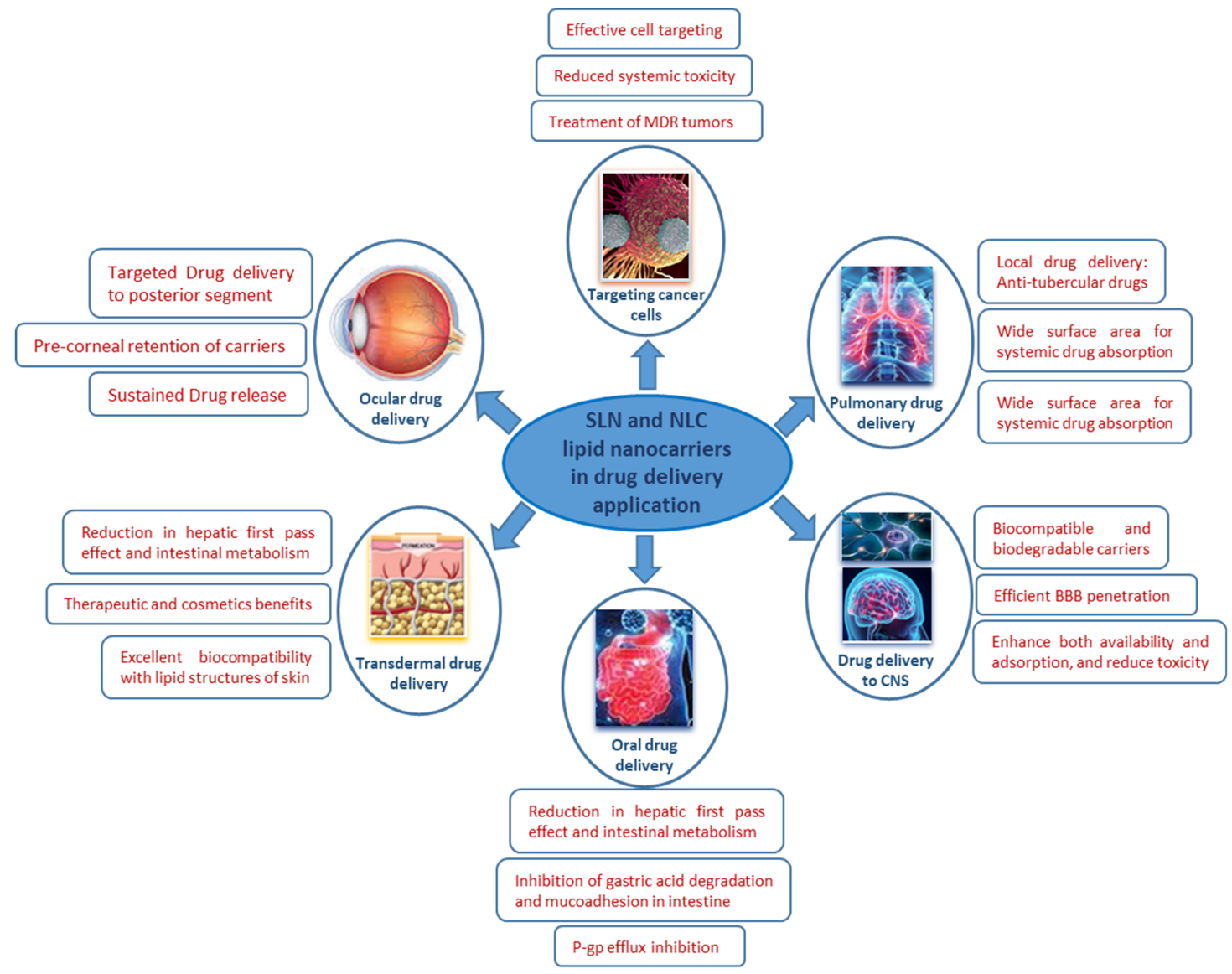

Figure 5. An overview of lipid nanocarriers as drug delivery systems in various therapeutic applications. 


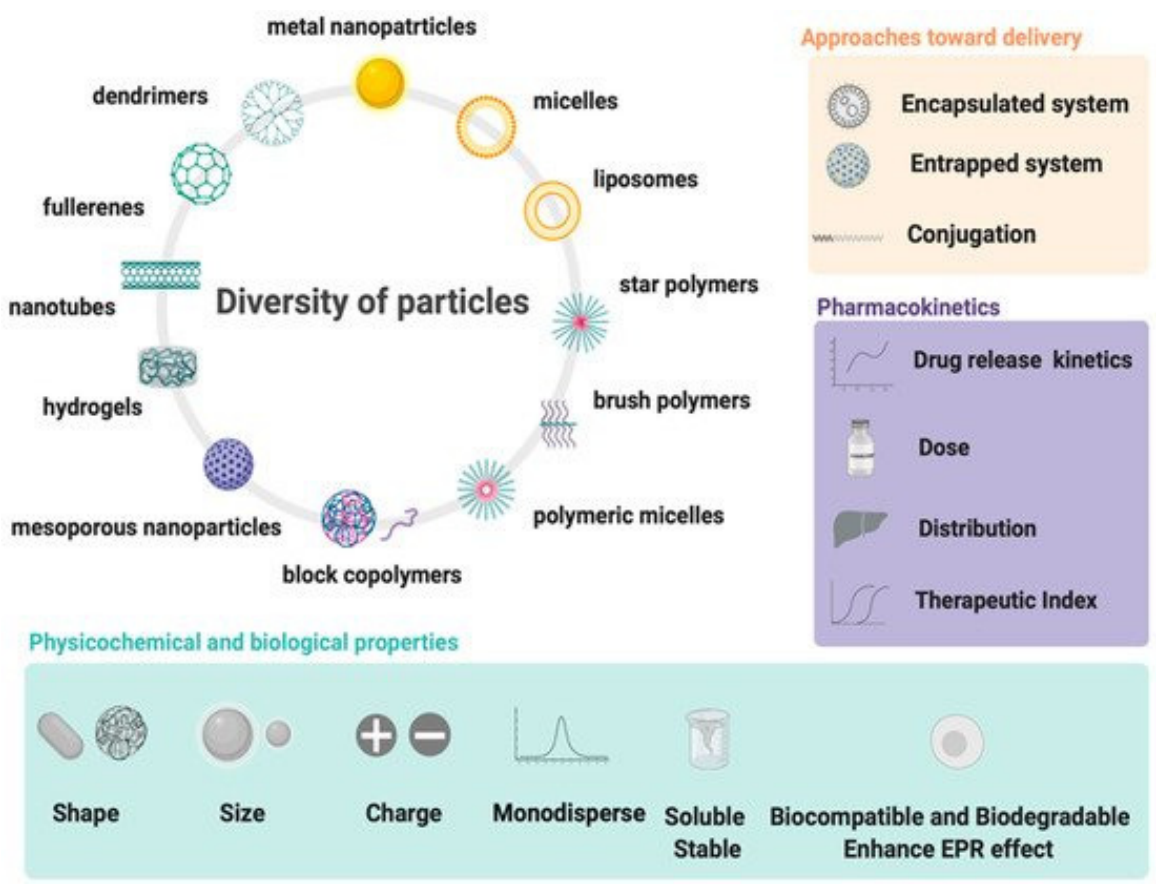

Figure 6. Design and properties requirements for drug delivery systems using wide spectrum of particles. Reprinted with permission from ref. [185]. Copyright 2021 MDPI.

Nanocarrier-based nanoparticles linked to different polymeric ligands were investigated as drug delivery across the blood-brain barrier [186].

Today, oxidative stress is implicated in most brain diseases, and intensifies the impact of tumor tissue. The bioactive polymer mPEG has recently shown its ability to respond to a stimulus of reactive oxygen species (ROS) with a ROS-cleavable moiety (thioketal) connecting the medical ingredient to the polymer [187]. This would increase the ability to target drugs, especially for those sites showing significant oxidative stress. Nanogels that are based on protective polymers have been effective in inhibiting amyloid $\beta$ (A $\beta$ ) fibril formulations [188,189], resulting in a reduced $A \beta$ cell toxicity in vitro [190]. In vivo inoculation of zinc-loaded polymeric poly(lactic-co-glycolic acid) (PLGA) nanoparticles with g7 ligand (g7 is a glycopeptide used for its ability to cross the BBB) for BBB (bloodbrain barrier) crossing revealed a significant reduction of plaque size recently [191,192].

The role of functional polymers and diverse forms of particles in drug delivery will expand considerably in the future to treat various unresolved issues (Figure 6). These problems may involve site-specific drug delivery in subcellular organelles, exploiting effectively the chemical, physical, and biological properties with the aim to optimize drug delivery behavior. Nanocomposites have been shown to penetrate deep blood-brainbarriers [193,194]. Nowadays, more knowledge is still needed regarding the biology of cell-polymer interactions, nano-safety, and industrial manufacturing.

Actually, bioactive natural polymers, such as chitosan, alginate, carrageenan, and various polysaccharide extracts from plants were grafted onto various textile biomaterials, including implants and wound dressings. Successful chemical grafting without altering the different mechanical, swelling, and microbiological properties of the grafted biopolymers afforded excellent and promising functionalized textile biomaterials with enhanced physical, bacterial, and biological performance [195-208].

Recently, nanofibrous materials via electrospinning technology were widely reported and shown to be effective in various biomedical applications, including tissue engineering, wound dressing, drug delivery, regenerative medicine, disease modeling, and sensing/biosensing [209-220] (Figure 7). These sustainable electrospun composite materials were efficient due to their ease of operation, nanoscale diameter, wide specific surface, high porosity, cost-effectiveness, and the large adaptability for engineering eco-friendly bioactive 
nanomaterials [221-225]. Electrospenning technology has been widely investigated in the field of drug delivery system thanks to its versatility in terms of producing nanofibers which combine several types of products in their initial composition. These nanofibers could be in different morphologies and structures, such as core-sheath [226] and janus [227]; this allows one to control the release rate of the incorporated biological ingredients. Indeed, a wide range of bioactive agents, such as anticancer drugs [228], antibiotics [229], RNA [230], and therapeutic proteins [231], have been successfully immobilized into electrospun polymeric nanomaterials of multiple designs that provide various drug release profiles, including sequential release [232], zero-order release [233], biphasic release [234], spatiotemporal release [235], and stimuli-triggered release [236]. Nowadays, nanofiber delivery systems based on stimuli-sensitive polymers have gained considerable attention in the field of drug delivery systems. These systems were designed to trigger the release of drugs spatiotemporally through chemical or physical stimuli. Several types of stimuli have been explored, including endogenous stimuli such as redox gradient, change in $\mathrm{pH}$, and sensitivity to enzymes, in addition to exogenous stimuli such as magnetic or electric fields, temperature, and light [236-238]. Singh et al. [239] prepared a poly(N-isopropylacrylamide) (PNIPAM) composite, stimuli-responsive nanofiber, comprising gold nanorods (GNRs), as an on-demand drug delivery system. Following the near-infrared (NIR) irradiation, the GNRs generate heat, which stimulates a thermal response of the PNIPAM, manifested by the shrinking of the nanofibers and thus the controlled release of the active principle. Cell studies have confirmed the performance of this light-sensitive nanomaterial in revealing its biocompatibility and the efficiency of its swelling and deswelling ability, as well as a controlled release with an efficient on-off behavior. Furthermore, the system has shown its potential in the successful combination of chemotherapy with several drugs to improve the effectiveness of complex cancer treatments. Mamidi et al. [240] designed a pH-responsive composite nanomaterial based on PCL/mercaptophenyl methacrylate grafted carbon nanoonions (f-CNOs), delivering doxorubicin (DOX). Under selected physiological conditions, interactions between DOX and the $\mathrm{f}-\mathrm{CNO}$ resulted in the prolonged and controlled release of DOX. Moreover, the nanocomposite exhibits a good cytoxicity and biocompatibility when in contact with human fibroblast cells.

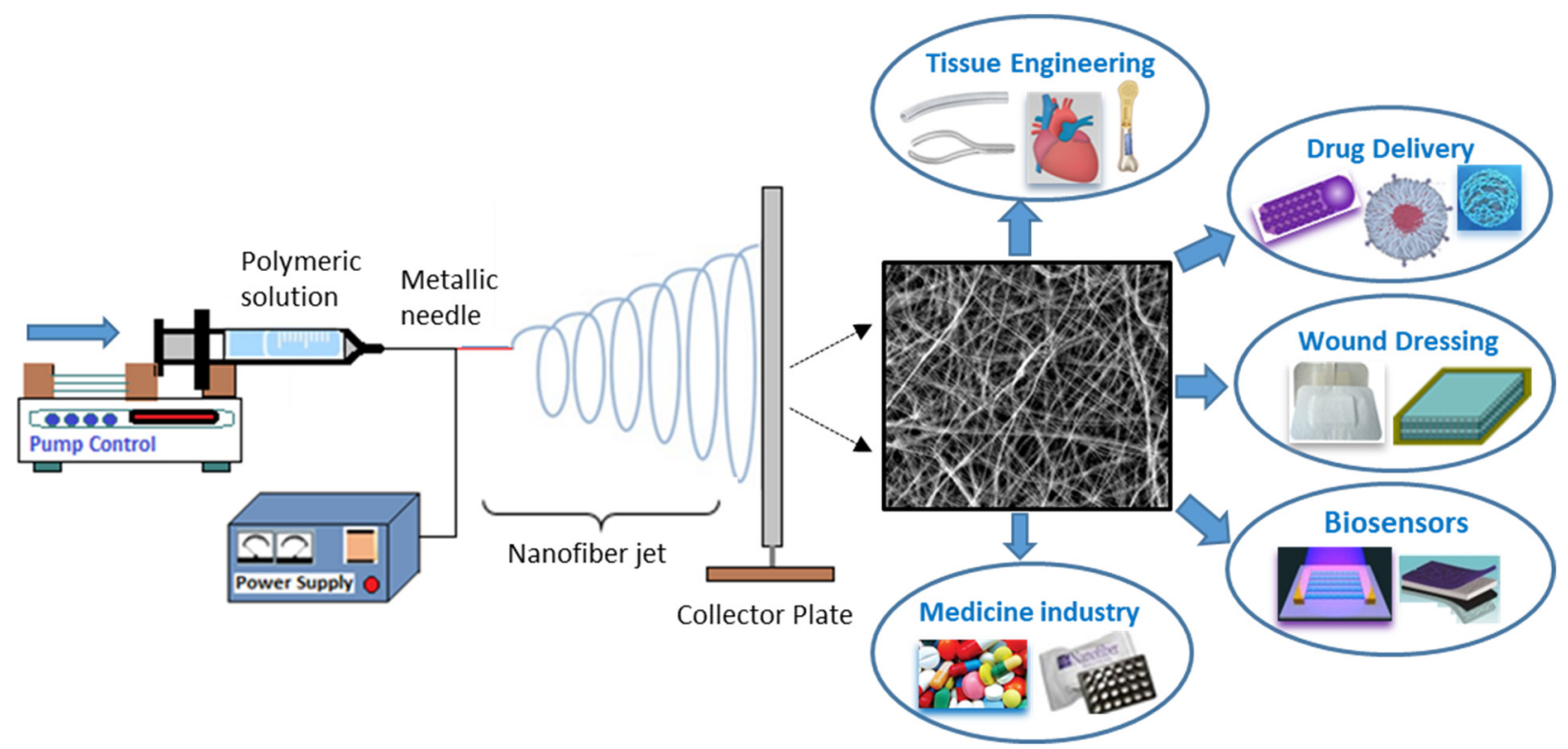

Figure 7. Scheme illustrating electrospun nanofibers process and their related biomedical applications.

Simultaneously, tissue engineering and regenerative medicine involve concepts bringing together different fields, including chemistry, biology, and materials science engineering. The development of technical and functional materials aimed at replacing or repairing 
diseased or damaged organs is a multiplex process that requires designed scaffold materials reminiscent of the cellular microenvironment with efficient cell metabolism, vitality, adhesion, and tissue regeneration. Over the past two decades, electrospinning has shown promise in the development of various effective fibrous scaffolds applied in different fields of regenerative medicine, including in dressings, as well as in cartilage, bone, neural, and cardiovascular tissue regeneration.

Indeed, for bone regeneration, many studies have focused on poly-caprolactone (PCL)/hydroxyapatite (HAp), based on nanofibers, and additives which have been studied for scaffold enhancement [241-243]. Liu et al. [244] developed a new hybrid bilayer scaffold based on electrospun PCL/gelatine (Gel) nano fibrous material, combined with a 3D printed PCL/Gel/nano-hydroxyapatite (n-HA) scaffold. Promising cell proliferation and adhesion results using L929 fibroblasts were obtained with the heparin-conjugated PCL/Gel nanofibrous material. The hybrid bilayer scaffolding revealed an excellent rate of new bone regeneration. Hashemi et al. [245] designed a 3D polylactic acid/polycaprolactone/gelatin electrospun scaffold with high porosity $(80 \%)$, and functionalized with ascorbic acid as a bone healing additive. Using a rat calvaria defect model, in vitro and in vivo evaluations of cell proliferation and bone healing were promising, and afford a valuable potential in osteogenesis and cell culture growth. Electrospinning technology was also the most effective strategy for producing nanofiber scaffolds for cartilage regeneration [246-248]. A wide range of bioactive molecules, including corticosteroids, drugs, and growth factors have been immobilized in electrospun nanofiber materials for the control of the inflammatory response and the regeneration of new cartilage tissue. Shen et al. [249] prepared an electrospun porous PLA/gelatin nanofibrous scaffold functionalized with chondroitin sulfate (CS), known to be used in the clinical treatment of cartilage disorders. The designed nanocomposite scaffold has demonstrated good mechanical and biocompatible properties, excellent cell proliferation, and crucial inflammatory inhibition. An in vivo study of rabbit cartilage defects revealed clear cartilage repair and a highly anti-inflammatory effect via the reduction of iNOS and PGES, enzymes producing NO and PGE2, respectively, by immunohistology. Chen et al. [250] fabricated a 2D poly (L-lactide-co- $\varepsilon$-caprolactone)/silk fibroin (PLCL/SF) (2DS) electrospun scaffold crosslinked with hyaluronic acid (HA) to further mimic the microarchitecture of native articular cartilage. The in vitro and in vivo evaluation of the 3D HAS biomimetic scaffold was promising and confirmed its ability as a potent candidate for cartilage tissue regeneration applications. To date, electrospinning has gained prominence in the production of innovative scaffolds for the regeneration of myocardial, valve, and vascular tissue. Eom et al. [251] has developed a multi-layered anisotropic scaffold with a 3D anisotropy comparable to that of native heart tissue, based on a polycaprolactone (PCL) nanofiber mat. In vitro cell culture of cardiomyocytes showed the spontaneous contraction of the prepared scaffold mat and demonstrated cell alignment and subsequent uniaxial contraction with aligned nanofibers. The stacked triple layers also exhibited multiaxial contraction, which potentially simulates the compressive force of the heart tissue. Numerous studies have reported the production of various electrospun nanofibrous scaffolds to be applied as skin substitutes and wound dressings [252-254]. Choi et al. [255] designed an electrospun polycaprolactone (PCL)/keratin scaffold as a multi-layered skin substitute, mimicking the real multi-layered skin anatomy. The PCL/keratin scaffold revealed good cell adhesion and proliferation on contact with a co-culture of keratinocytes and fibroblasts. In addition, in vivo assays showed the rapid regeneration of new skin without scar formation. Hivechi et al. [256] prepared an exopolysaccharide/PCL/gelatin electrospun nanofibrous material as a skin substitute. The nanocomposite scaffold showed good biocompatibility and cell viability behaviors. The in vivo implantation of the electrospun nanofiber on the full-thickness wound on rat models exhibited rapid healing efficiency.

\section{Industrial Water Treatment Applications}

Polymers play an important role in the water sector. They could be used as chemical additives (as soluble polymers) in water treatment and desalination plants to reduce scale 
formations and increase water productivity, as coating material to protect water tanks and transmission lines from corrosion, or as materials for membrane manufacturing for water treatment and desalination applications. Another recent investigation of polymers and functional polymers concerns their use in the adsorption of different organic and metallic pollutants from industrial wastewater. Below is a brief overview of the global market value and some examples of polymeric materials that can be used in the water sector (Figure 8).

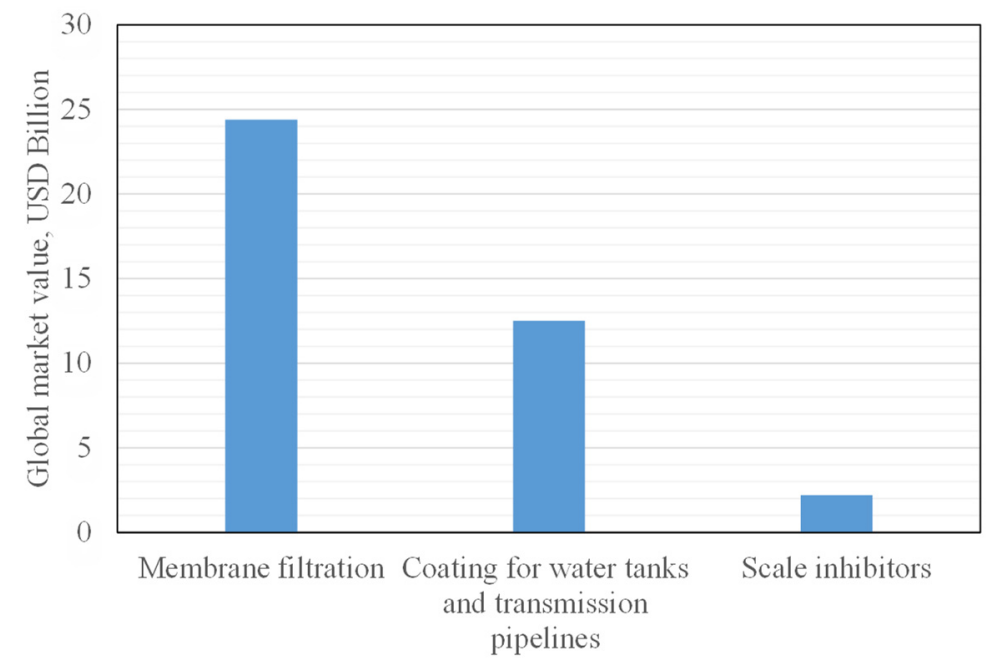

Figure 8. Global market value of some industrial polymeric products.

\subsection{Chemical Additives}

Chemical additives are used in many water applications, such as water treatment, water desalination, and in oil field activities [257]. The global market of scale inhibitors was worth USD 2.26 billion in 2014 and was projected to increase by $4.73 \%$ between 2015 and 2020 [258]. There are increasing demands on the use of soluble polymeric additives that are effective, safe to use, and environmentally friendly. Many soluble polymer additives are available in the market, some of which are used in the water treatment and desalination process as scale coagulant aids and scale inhibitors [259-261]. The most effective and famous additives are poly(acrylic acid), poly(methacrylic acid), and poly(Maleic acid) which are widely used as scale inhibitors in thermal plants [262-264] for reducing scale formation and increasing process performance. Another kind of polymeric additives for water desalination using membrane processes is polyamino polyether methylenephosphonate (PAPEMP), which is an ideal additive as it controls calcium carbonate and calcium sulfate scale formation and deposition $[265,266]$. Addition of this chemical could reduce or eliminate acid feed, therefore reducing hazardous risk and increasing water production. Recently, a zero generation (0G) polyamidoamine (0G means a dendrimer with only the central core), as an amine-terminated dendrimer (PAMAM) with a reactive core of 1,3-diaminopropane, has been synthesized for the inhibition of silica scale contaminant. This polymeric membrane has shown excellent scale-inhibiting properties and has shown its effectiveness as a novel water treatment membrane [267].

\subsection{Polymeric Membranes}

Polymeric membrane technologies that have been explored in the treatment and desalination of water are continuously developed and widely studied, with the aim of meeting the global challenges of water security and supply. The relevant polymer-based membranes have today become one of the most interesting materials, exploited in many fields such as water treatment, water desalination, and food processing [268-270]. The global membrane filtration market size is expected to reach USD 24.4 billion by 2026 [271]. There are many polymeric materials that can be used for membrane filtration which depends on the application area. They can be used as microfiltration (MF) or ultrafiltration 
(UF) devices for the removal of suspended solids and microorganisms, or large chemical molecules and colloidal particles. Those membranes are mainly made by polypropylene (PP), poly(vinylidene fluoride) (PVDF) and polytetrafluoroethylene (PTFE), due to their durability and availability, as well as their excellent thermal and mechanical stability.

Other useful applications are nanofiltration (NF) and reverse osmosis (RO) membranes for the removal of dissolved salts from water. Polysulphone (PS) and poly(ethersulphone) (PES) and polyacrylonitrile (PAN) are some examples of the materials that are used as a membranes or membrane substrate for NF or RO applications [272-274]. Polyamide or cellulose acetate are examples of polymeric materials that are used for fabricating composite membrane for reverse osmosis or nanofiltration [275-277].

\subsection{Polymers in the Treatment of Industrial Wastewaters}

Water pollution by organic matter is a global problem, whose aspects and scope are obviously different according to the level of development of the countries involved. It is important today to work and make every effort to reduce the concentrations of pollutants from industrial wastewater. Pollution by toxic organic waste is more insidious than a direct pollution (odor, cloudiness) because it is less remarkable. The health of living organisms is slowly deteriorating, their lives are shortened, their descendants may be affected by malformations, their probability of being reached by cancer will increase, and the aquatic fauna is not the only one concerned. We ingest these same toxic pollutants without having them in our proximity, through the food chain, by consuming the flesh of these living organisms, vegetables, fruits, vegetables, etc.

Dyes are among the most dangerous organic pollutants, and they are often found in the environment as a result of their wide industrial use. These industrial pollutants are common contaminants in wastewater. The textile, paper-making, cosmetic, pharmaceuticals, food coloring, and pulp industries are reported to be the source of large amounts of pollutant dye discharged into wastewater. These colored wastewater pollutants are toxic and even carcinogenic, posing a serious danger to living aquatic organisms [278,279]. This interesting topic requires the development of various technologies to treat colored waters. Biological treatment and coagulation/flocculation processes are viewed as ineffective to treat soluble dyes [280-282]. Adsorption using polymeric materials has appeared to be more effective, as it is simple and economic and it is especially used to remove pollutants, which are not easily biodegradable. Thus, a specific attention is devoted to explore new polymeric adsorbents, which could be cheaper, more proficient, and easily regenerated [283-285].

In this sense, several synthetic polymeric adsorbents have been used for the removal of organic dyes from contaminated matters [286-288]. Among these synthetic polymers investigated as adsorbents of organic dyestuffs, we can mention the use of PVA, and various composite materials based on PVA [289-293]. Conductive polymers have also been investigated to be effective adsorbents. Indeed, the polyaniline and polypyrrole polymers, as well as their related materials and composites, have revealed in the literature excellent adsorption capacities of various dyes and organic pollutants. [294-296]. Synthesized polymers based on cyclodextrins macromolecules have been studied as adsorbents for different basic dyes in aqueous solution. These adsorbents exhibited high sorption capacities [297-299]. Magnetic nanoparticles which were modified by different polymers (3-aminopropyltriethoxysilane) and copolymers of acrylic acid, or crotonic acid, have shown promising performances for removing various aqueous pollutants $[300,301]$. Silver-based coordination polymers were developed and demonstrated good adsorptive performances toward a series of organic dyes with sulfonic groups [302].

In recent years, natural polymeric bio-sorbents are gaining more interest over synthetic classical adsorbents, due to their tunable physicochemical properties, structural diversity, reusability, and environmental benefits [303-305]. Indeed, several low-cost polymeric adsorbents have been prepared through the valorization and the functionalization of wastes from different sources, such as plants, fish shells, marine algae (green, brown and red species), vegetables, etc. [306-309]. These materials are sources of cellulose, chitosan, 
sodium alginate, carrageenan, lignin, etc. These natural polymers have been exploited either directly after extraction or by mixing them in polymeric composites for more compactness and especially efficiency [310-317]. The adsorption results of various organic pollutants have been very promising in terms of their absorption capacity, simplicity of operation designs, cost-effective aspects, and reuse. [318,319]. Very recently, a new procedure for exploring natural polymers as effective adsorbent materials has been investigated. Thus, certain biodegradable textile polymeric materials, such as cellulose, have been functionalized by different extracted natural polymers (chitosan, carrageenan, alginate, etc.). This is a simple and economical method offering permanent and stable natural adsorbents with high adsorption capacities [320,321].

Hereafter, we present an overview of the various natural adsorbent materials studied in the adsorption of organic waste pollutants (Table 1).

Table 1. A synthesis of the various recent natural polymeric bio-sorbents and their composites studied for the adsorption of anionic and cationic dyes from industrial wastewater.

\begin{tabular}{|c|c|c|c|c|}
\hline Adsorbent & Adsorbate & $q_{t}\left(m g \cdot g^{-1}\right)$ & $\begin{array}{c}\text { Adsorption Efficiency } \\
(\%)\end{array}$ & References \\
\hline Luffa Cylindrica fibers & Malachite green/MB & $63 / 52$ & $96.72 / 94.40$ & [322] \\
\hline Bean peel & Cibaron Blue & 5.72 & 95.31 & [323] \\
\hline Eichhornia crassipes roots & $4 \mathrm{~B}$ red reactive & 43.28 & 95 & [324] \\
\hline Dead Typha angustifolia (L.) leaves & MB & 106.75 & 89.83 & [325] \\
\hline Almond shell & MB & 84.9 & & [326] \\
\hline Salix babylonica leaves & MB & 60.97 & & [327] \\
\hline Prickly (peel) bark of cactus fruit & MB & 222 & & [328] \\
\hline $\begin{array}{l}\text { k-carrageenan/alginate/cellulose } \\
\text { PEM }\end{array}$ & MB & 522.4 & 98.6 & [329] \\
\hline Coconut mesocarp & $\begin{array}{l}\text { Remazol golden yellow } \\
\text { Reactive gray BF-2R } \\
\text { Reactive turquoise Q-G125 }\end{array}$ & $\begin{array}{l}6.8 \\
4.8 \\
4.1 \\
\end{array}$ & $\begin{array}{l}94.9 \\
100 \\
96.6 \\
\end{array}$ & [330] \\
\hline Banana peels & $\begin{array}{l}\text { Remazol golden yellow } \\
\text { Reactive gray BF-2R } \\
\text { Reactive turquoise Q-G125 }\end{array}$ & $\begin{array}{l}2.5 \\
1.2 \\
1.6\end{array}$ & $\begin{array}{c}70.2 \\
75.4 \\
100 \\
\end{array}$ & [330] \\
\hline Typha australis Leaves & Malachite green & 85.21 & - & [331] \\
\hline $\begin{array}{l}\text { white pine (Pinus durangensis) } \\
\text { sawdust }\end{array}$ & MB & 87 & 86 & [332] \\
\hline pineapple (Ananas comosus) leaf & Remazol Brilliant Blue R & 9.66 & 96.20 & [333] \\
\hline Lime (Citrus aurantifolia) peel & Remazol Brilliant Blue R & 9.58 & 95.89 & [333] \\
\hline Coconut bunch & Remazol Brilliant Blue R & 9.48 & 94.76 & [333] \\
\hline Coconut fiber & Remazol Brilliant Blue R & 9.55 & 95.48 & [333] \\
\hline Chili seeds & Remazol Brilliant Blue R & 9.40 & 93.97 & [333] \\
\hline Guava leaves & Remazol Brilliant Blue R & 9.41 & 94.09 & [333] \\
\hline Coconut residue & Remazol Brilliant Blue R & 9.38 & 93.85 & [333] \\
\hline Jackfruit peels & Remazol Brilliant Blue R & 9.23 & 92.26 & [333] \\
\hline Orange peel & Remazol Brilliant Blue R & - & 11.4 & {$[334,335]$} \\
\hline Spent tea leaves & Remazol Brilliant Blue R & 9.7 & - & [334] \\
\hline Salvinia natans & Remazol Brilliant Blue R & 61.9 & - & [336] \\
\hline Durian peel & Remazol Brilliant Blue R & - & 14.9 & [336] \\
\hline watermelon rind & $\begin{array}{c}\text { MB } \\
\text { Brilliant green } \\
\text { Remazol Brilliant Blue R } \\
\text { Congo red CR } \\
\text { Orange G }\end{array}$ & $\begin{array}{c}200 \\
188.6 \\
333.33 \\
17 \\
27\end{array}$ & $\begin{array}{c}99 \\
98 \\
92-97 \\
100 \\
85\end{array}$ & $\begin{array}{c}{[337]} \\
{[338]} \\
{[339,340]} \\
{[341]} \\
{[342]}\end{array}$ \\
\hline
\end{tabular}


Table 1. Cont.

\begin{tabular}{|c|c|c|c|c|}
\hline Adsorbent & Adsorbate & $q_{t}\left(m g \cdot g^{-1}\right)$ & $\begin{array}{c}\text { Adsorption Efficiency } \\
(\%)\end{array}$ & References \\
\hline Cyanthilium cinereum L. H. Rob weeds & MB & 76.336 & 95 & [343] \\
\hline Paspalum maritimum (PMT) & MB & 56.179 & 97 & [343] \\
\hline Carica papaya wood & MB & 32.25 & & [344] \\
\hline pupunha palm & MB & 78.989 & & [345] \\
\hline Potato shell & MB & 48.7 & & [346] \\
\hline Scenedesmus & MB & 61.69 & & [346] \\
\hline Maize silk powder & MB & 132.1 & & [347] \\
\hline Lignin sulfonate polymer & Malachite green & 27.4 & 60 & [348] \\
\hline $\begin{array}{l}\text { Lignin sulfonate- } g \text {-poly(acrylic } \\
\text { acid- } r \text {-acrylamide) }\end{array}$ & Malachite green & 97 & 97 & [349] \\
\hline Microalgae Scenedesmus & MB & 87.69 & - & [350] \\
\hline $\begin{array}{l}\text { activated carbon prepared from Date Press } \\
\text { Cake }\end{array}$ & MB & 613.8 & 83.3 & [351] \\
\hline Karanj fruit hulls & MB & 239.4 & 94.4 & [352] \\
\hline Rattan (Lacosperma secundiflorum) & MB & 359 & 96 & [353] \\
\hline Fox nutshell & MB & 968.7 & 99.96 & [354] \\
\hline $\begin{array}{l}\text { chitosan-epichlorohydrin/zeolite } \\
\text { composite }\end{array}$ & $\begin{array}{c}\text { MB } \\
\text { Reactive red } 120\end{array}$ & $\begin{array}{c}44.2 \\
45.25\end{array}$ & $\begin{array}{l}90 \\
88\end{array}$ & [355] \\
\hline chitosan/carboxymethyl cellulose capsules & $\begin{array}{c}\text { MB } \\
\text { Methyl orange } \\
\text { Acid blue-113 }\end{array}$ & $\begin{array}{c}64.6 \\
334.8 \\
526.8\end{array}$ & $\begin{array}{c}4.4 \\
37.5 \\
59 \\
\end{array}$ & [356] \\
\hline $\begin{array}{l}\text { Polyacrylamide-chitosan magnetic } \\
\text { nanoparticles }\end{array}$ & MB & 1044.06 & 76.1 & [357] \\
\hline $\begin{array}{c}\text { chitosan-epichlorohydrin } / \mathrm{TiO}_{2} \\
\text { nanocomposite }\end{array}$ & Reactive red 120 & 46.3 & 99.3 & [358] \\
\hline polypyrrole-chitosan composites & Acid red 18 & 285.71 & 98.93 & [359] \\
\hline Chitosan-Activated Charcoal Composite & Thionine cationic dye & 60.9 & 92.9 & [360] \\
\hline chitosan-glyoxal/ $\mathrm{TiO}_{2}$ nanocomposite & Methyl orange & 374.8 & 75.9 & [361] \\
\hline chitosan/polyamide nanofibers & $\begin{array}{c}\text { Ponceau } 4 \mathrm{R} \\
\text { Reactive Black } 5\end{array}$ & $\begin{array}{l}482.2 \\
352.5\end{array}$ & - & [362] \\
\hline Chitosan/alginate composite sponge & Acid red B14 & 1486.9 & - & [363] \\
\hline fibrous chitosan/alginate composite foam & $\begin{array}{c}\text { MB } \\
\text { Acid Black-172 }\end{array}$ & $\begin{array}{c}1488.1 \\
817\end{array}$ & $\begin{array}{l}- \\
-\end{array}$ & [364] \\
\hline Sodium alginate nanofiber membranes & MB & 2230 & - & [365] \\
\hline $\begin{array}{l}\text { Sodium alginate/gelatin/graphene oxide } \\
\text { composite aerogel }\end{array}$ & $\begin{array}{c}\mathrm{MB} \\
\text { Congo red }\end{array}$ & $\begin{array}{l}322.6 \\
196.8\end{array}$ & - & [366] \\
\hline $\begin{array}{l}\text { Lignin/cellulose nanocrystals/alginate } \\
\text { beads }\end{array}$ & MB & 1181 & - & [367] \\
\hline Cladodes of Tacinga palmadora & Crystal violet & 228.74 & - & [368] \\
\hline Palm cactus & Crystal violet & 220 & - & [369] \\
\hline O. ficus indica cladodes & Acid orange & 198.9 & - & [370] \\
\hline Cactus pear seed cake & $\begin{array}{c}\text { MB } \\
\text { Methyl orange }\end{array}$ & $\begin{array}{c}260 \\
336.12\end{array}$ & $\begin{array}{c}56.48 \\
100\end{array}$ & [371] \\
\hline Fruit peels (O. ficus indica) & $\begin{array}{c}\text { Indigo carmine } \\
\text { Solophenyl blue } \\
\text { MB } \\
\text { Crystal violet }\end{array}$ & $\begin{array}{l}294 \\
909 \\
416 \\
312 \\
\end{array}$ & $\begin{array}{l}76-99 \\
76-99 \\
76-99 \\
76-99 \\
\end{array}$ & [372] \\
\hline $\begin{array}{l}\text { Carboxymethyl chitosan-modified } \\
\text { magnetic-cored dendrimers }\end{array}$ & $\begin{array}{c}\text { MB } \\
\text { Methyl orange }\end{array}$ & $\begin{array}{l}20.85 \\
96.31\end{array}$ & - & [373] \\
\hline
\end{tabular}


Table 1. Cont.

\begin{tabular}{|c|c|c|c|c|}
\hline Adsorbent & Adsorbate & $q_{t}\left(m g \cdot g^{-1}\right)$ & $\begin{array}{l}\text { Adsorption Efficiency } \\
(\%)\end{array}$ & References \\
\hline Gelatin-based magnetic beads & $\begin{array}{c}\text { MB } \\
\text { Direct Red }\end{array}$ & $\begin{array}{l}465 \\
380\end{array}$ & - & [374] \\
\hline $\begin{array}{c}\text { Glutaraldehyde cross-linked } \\
\text { chitosan-coated } \mathrm{Fe}_{3} \mathrm{O}_{4} \text { nanoparticles }\end{array}$ & Methyl orange & 758 & - & [375] \\
\hline $\begin{array}{l}\text { Magnetic hydrogel beads with gum } \\
\text { tragacanth }\end{array}$ & Congo Red & 94 & - & [376] \\
\hline $\begin{array}{c}\mathrm{Fe}_{3} \mathrm{O}_{4}-\mathrm{K} \text {-carrageenan cross-linked with } \\
\text { chitosan }\end{array}$ & MB & 123 & & [377] \\
\hline $\mathrm{Fe}_{3} \mathrm{O}_{4} @ \mathrm{SiO}_{2}-\mathrm{K}$-carrageenan & MB & 530 & - & [378] \\
\hline Potamogeton crispus & RR198 & 44.2 & - & [379] \\
\hline $\begin{array}{c}\text { O-carboxymethylchitosan-N-lauryl } / \gamma \text { - } \\
\mathrm{Fe}_{2} \mathrm{O}_{3} \text { magnetic } \\
\text { nanoparticles }\end{array}$ & RR198 & 216 & - & [380] \\
\hline Pistachio hull wastes & RR198 & 253.67 & 95.13 & [381] \\
\hline $\mathrm{Al}_{2} \mathrm{O}_{3} / \mathrm{MWCNTs}$ Carbon nanotube & RR198 & 424 & 91.54 & [382] \\
\hline Polyaniline $/ \mathrm{Fe}_{3} \mathrm{O}_{4}$ & RR198 & 45.45 & 92.1 & [383] \\
\hline Eggshell biocomposite beads & RR198 & 46.9 & 92 & [384] \\
\hline Activated Carbon (Walnut Shells) & RR198 & 79.15 & 87.17 & [385] \\
\hline Pistachio nut shell & RR198 & 108.15 & 88 & [386] \\
\hline Chitosan & RR198 & 310.4 & 95.11 & [387] \\
\hline Chitosan/cellulose PEM & RR198 & 819 & 99.77 & [388] \\
\hline Cellulose/chitosan aerogels & Congo Red & 381.7 & 95 & [389] \\
\hline Chitosan/Zeolite composite & MB & 19.23 & 84.85 & [390] \\
\hline Chitosan/PVA composite & $\begin{array}{l}\text { Methyl orange } \\
\text { Eosin Yellow Dye }\end{array}$ & $\begin{array}{c}9.34 \\
52.91\end{array}$ & $\begin{array}{l}92.42 \\
86.70\end{array}$ & $\begin{array}{l}{[391]} \\
{[392]}\end{array}$ \\
\hline Chitosan/ZnO & Malachite Green Dye & - & 98.50 & [393] \\
\hline
\end{tabular}

Furthermore, some novel adsorbent designs based on polyelectrolyte multilayered (PEM) bio-polymeric materials as potent bio-sorbents were studied $[329,388]$. These adsorbents were prepared by an alternation of layers of two polyelectrolyte biopolymers via a layer-by-layer grafting method. Different layers were grafted to a natural cellulosic non-woven material and providing thereby many practical advantages (Figure 9). Various natural polymers were investigated and combined, such as chitosan, alginate, carrageenan, etc. Polyanionic polymers were effective in adsorbing positively charged molecules (Figure 10) and grafted polycationic polymers demonstrated an excellent performance in removing negatively charged molecules and dye wastes. Overall, the covalent immobilization of the biopolymer on the surface of the material has been beneficial in ensuring the successful recycling and reuse of bio-sorbents without significant loss in adsorption performance. The adsorption capacity results were therefore very interesting, in addition to their low cost and easy reuse.

Finally, due to the specific selectivity of polymeric materials, which are functionalized via a wide variety of polymers having various active groups, such as amines, hydroxyl, carboxylic, phosphonic, and sulfonic, towards the target pollutant, particular attention will be given to these. 


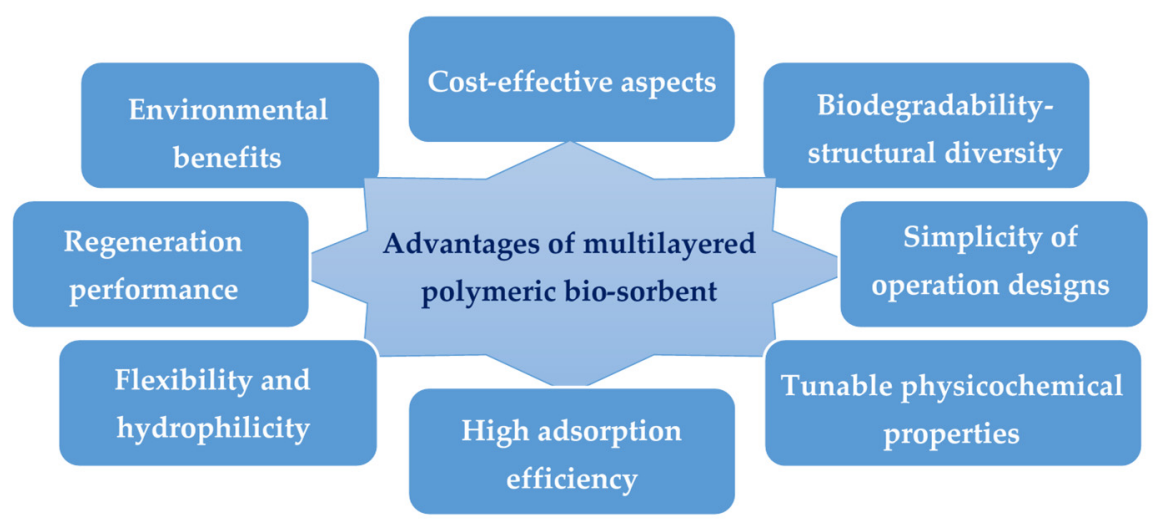

Figure 9. Benefits of natural multilayered polymeric bio-sorbents for the adsorption of organic pollutants from industrial wastewater.

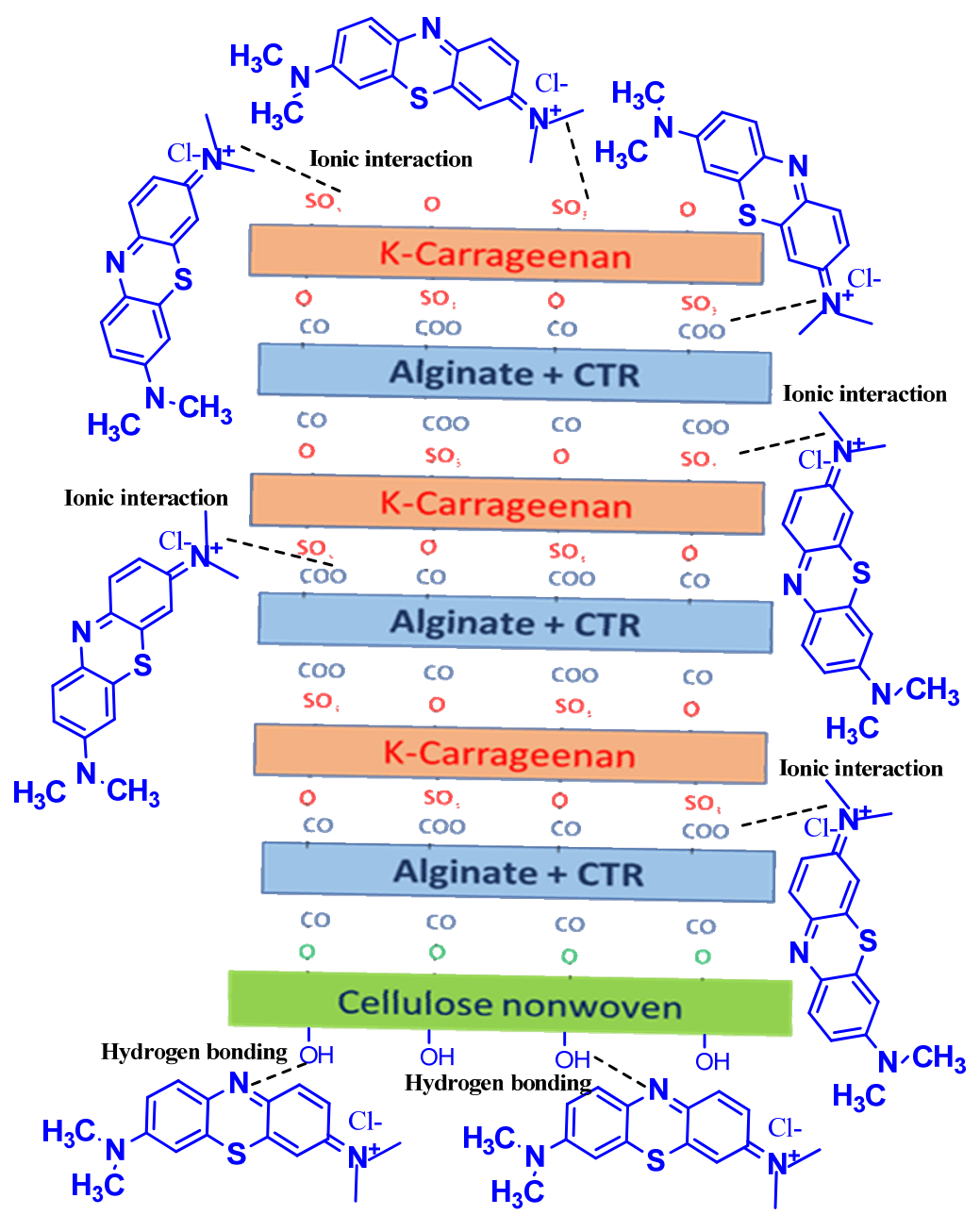

Figure 10. Illustration of different interactions between methylene blue molecule and the surface of multilayered polymeric material (Alginate and Carrageenan) crosslinked to non-woven cellulosic bio-sorbent. Reprinted with permission from MDPI [329], Copyright 2021.

\subsection{Other Applications in Water Sector}

Protecting water tanks and transmission pipelines with a properly coated material, to avoid or minimize corrosion, is essential for extending the lifetime of storage tanks and pipes, as well as for maintaining water quality. Nowadays, there are many coating materials, such as acrylic, polyurethane, epoxy, etc. that are used for many industrial and 
marine works. The market size is estimated at USD 8.7 billion in 2018 and is projected to reach USD 12.5 billion by 2023 [394]. Polyurea is also perfect for water tank lining, due to its elasticity, thermal stability, and ease of use. Polyurea can be effective in protecting steel, aluminium, and fiberglass in a variety of water activities and commercial marine applications $[395,396]$. These chemicals, or other alternative chemicals with similar properties and usage, could be formulated and manufactured to cover industrial demands and to increase the business in the local contents of these materials. Functional polymers and their composites were also applied for water treatment and desalination. Different polymeric composites were thus prepared and studied, such as polymer-carbon composites [397], polymer graphene composites [398], polymer-based activated carbon composites [399], and polymer anionic/cationic clay composites [400].

The development of polymeric materials is becoming the most promising future alternative to meet environmental water standards and to grant the water needs of growing populations.

\section{Conclusions}

As shown in this review, synthetic and natural polymers exhibit excellent effective performance in many areas of application. Recent continuous development in various polymer functionalization technologies and nanotechnologies have endowed polymeric materials with more interesting properties and tracing functionalities, promising to overcome the various problems and shortcomings downgrading the impact and the efficiency of polymers in their applications. Therefore, the simple combination of various native polymers cannot fulfill all the required properties, and thus, surface functionalization represents an efficient alternative and a crucial strategy that grants new a performance with added value. In this perspective, the functionalization methods emerge as a basic line for the obvious improvement of the functionalities of these applied materials. Despite the significant progress in recent years and the high level of success of polymer functionalization in different fields, several challenges still remain, and there is room yet for various improvements. First of all, a comprehensive and precise knowledge of the biological mechanisms of cell-polymer interactions could guarantee better design improvement. Indeed, many pathways related to cell uptake, cell adhesion kinetics, cytotoxicity, etc., are still under study and a common theory should be established. Concerning energy applications, as discussed, various studies have indeed confirmed the great potential of functional polymer materials for the production and storage of sustainable energy. However, their use for such applications has encountered greater challenges in their commercial adoption, due to the lack of strategies that converge manufacturing speed and precision to produce cost-effective, efficient, and selective devices. In addition, further studies are still needed to assess the long term stability of such polymer systems.

Furthermore, the passage from the laboratory scale for the various polymer applications in industrial production is not evident, and still has many deficiencies and gaps. In addition, there is typically the problem of a large delay, of great requirements, and complicated laws for a finished product to be industrialized and commercially available.

In summary, by solving all these problems and overcoming the various obstacles, we can affirm that natural and synthetic functional polymers and their composites represent a milestone for diverse energy, environmental, and biomedical applications and they guarantee an optimistic and promising future.

Author Contributions: Conceptualization, Y.E.-G., F.M.A. (Fahad M. Alminderej) and F.M.A. (Fehaid M. Alsubaie); methodology, Y.E.-G. and F.M.A. (Fehaid M. Alsubaie); software, Y.E.-G., F.M.A. (Fahad M. Alminderej), R.A. and N.H.A.; validation, Y.E.-G., F.M.A. (Fahad M. Alminderej) and F.M.A. (Fehaid M. Alsubaie); investigation, F.M.A. (Fahad M. Alminderej), Y.E.-G. and F.M.A. (Fehaid M. Alsubaie); writing-original draft preparation, Y.E.-G. and F.M.A. (Fahad M. Alminderej), R.A., F.M.A. (Fahad M. Alminderej) and N.H.A.; writing-review and editing, Y.E.-G. and F.M.A. (Fahad M. Alminderej); supervision, F.M.A. (Fahad M. Alminderej) and F.M.A. (Fehaid M. Alsubaie). All authors have read and agreed to the published version of the manuscript. 
Funding: This research received no external funding.

Institutional Review Board Statement: Not applicable.

Informed Consent Statement: Not applicable.

Data Availability Statement: The data presented in this study are available on request from the corresponding authors.

Conflicts of Interest: The authors declare no conflict of interest.

\section{References}

1. Su, L.; Weaver, J.L.; Groenenboom, M.; Nakamura, N.; Rus, E.; Anand, P.; Jha, S.K.; Okasinski, J.S.; Dura, J.A.; Reeja-Jayan, B. Tailoring Electrode-Electrolyte Interfaces in Lithium-Ion Batteries Using Molecularly Engineered Functional Polymers. ACS Appl. Mater. Interfaces 2021, 13, 9919-9931. [CrossRef]

2. Arreguin-Campos, R.; Jiménez-Monroy, K.L.; Diliën, H.; Cleij, T.J.; van Grinsven, B.; Eersels, K. Imprinted Polymers as Synthetic Receptors in Sensors for Food Safety. Biosensors 2021, 11, 46. [CrossRef]

3. Alashrah, S.; El-Ghoul, Y.; Omer, M.A.A. Synthesis and Characterization of a New Nanocomposite Film Based on Polyvinyl Alcohol Polymer and Nitro Blue Tetrazolium Dye as a Low Radiation Dosimeter in Medical Diagnostics Application. Polymers 2021, 13, 1815. [CrossRef]

4. D'Agata, R.; Bellassai, N.; Jungbluth, V.; Spoto, G. Recent Advances in Antifouling Materials for Surface Plasmon Resonance Biosensing in Clinical Diagnostics and Food Safety. Polymers 2021, 13, 1929. [CrossRef] [PubMed]

5. Alashrah, S.; El-Ghoul, Y.; Almutairi, F.M.; Omer, M.A.A. Development, Characterization and Valuable Use of Novel Dosimeter Film Based on PVA Polymer Doped Nitro Blue Tetrazolium Dye and $\mathrm{AgNO}_{3}$ for the Accurate Detection of Low X-ray Doses. Polymers 2021, 13, 3140. [CrossRef]

6. Wu, D.; Shi, W.; Ding, S.; Xie, X. Diverse functional groups decorated, bifunctional polyesteramide as efficient $\mathrm{Pb}(\mathrm{II})$ electrochemical probe and methylene blue adsorbent. Eur. Polym. J. 2021, 160, 110810. [CrossRef]

7. Shi, H.; Dai, Z.; Sheng, X.; Xia, D.; Shao, P.; Yang, L.; Luo, X. Conducting polymer hydrogels as a sustainable platform for advanced energy, biomedical and environmental applications. Sci. Total Environ. 2021, 786, 147430. [CrossRef] [PubMed]

8. Reddy, M.S.B.; Ponnamma, D.; Choudhary, R.; Sadasivuni, K.K. A Comparative Review of Natural and Synthetic Biopolymer Composite Scaffolds. Polymers 2021, 13, 1105. [CrossRef]

9. Mohd Nurazzi, N.; Asyraf, M.R.M.; Khalina, A.; Abdullah, N.; Sabaruddin, F.A.; Kamarudin, S.H.; Ahmad, S.; Mahat, A.M.; Lee, C.L.; Aisyah, H.A.; et al. Fabrication, Functionalization, and Application of Carbon Nanotube-Reinforced Polymer Composite: An Overview. Polymers 2021, 13, 1047. [CrossRef] [PubMed]

10. Wieszczycka, K.; Staszak, K.; Woźniak-Budych, M.J.; Litowczenko, J.; Maciejewska, B.M.; Jurga, S. Surface functionalization-The way for advanced applications of smart materials. Coord. Chem. Rev. 2021, 436, 213846. [CrossRef]

11. Liyanage, S.; Acharya, S.; Parajuli, P.; Shamshina, J.L.; Abidi, N. Production and Surface Modification of Cellulose Bioproducts. Polymers 2021, 13, 3433. [CrossRef] [PubMed]

12. Ngo, H.-T.; Hong, K.V.T.; Nguyen, T.-B. Surface Modification by the DBD Plasma to Improve the Flame-Retardant Treatment for Dyed Polyester Fabric. Polymers 2021, 13, 3011. [CrossRef] [PubMed]

13. Zhang, D.; Ouyang, Q.; Hu, Z.; Lu, S.; Quan, W.; Li, P.; Chen, Y.; Li, S. Catechol functionalized chitosan/active peptide microsphere hydrogel for skin wound healing. Int. J. Biol. Macromol. 2021, 173, 591-606. [CrossRef]

14. Basinska, T.; Gadzinowski, M.; Mickiewicz, D.; Slomkowski, S. Functionalized Particles Designed for Targeted Delivery. Polymers 2021, 13, 2022. [CrossRef] [PubMed]

15. Zheng, K.; Niu, W.; Lei, B.; Boccaccini, A.R. Immunomodulatory bioactive glasses for tissue regeneration. Acta Biomater. 2021, 133, 168-186. [CrossRef] [PubMed]

16. Andrade, R.G.D.; Reis, B.; Costas, B.; Lima, S.A.C.; Reis, S. Modulation of Macrophages M1/M2 Polarization Using CarbohydrateFunctionalized Polymeric Nanoparticles. Polymers 2021, 13, 88. [CrossRef]

17. Zhou, Z.; Ren, L.; Zhang, L.; Zhong, J.; Xiao, Y.; Jia, Z.; Guo, L.; Yang, J.; Wang, C.; Jiang, S.; et al. Heightened Innate Immune Responses in the Respiratory Tract of COVID-19 Patients. Cell Host Microbe 2020, 27, 883-890. [CrossRef]

18. Yoo, S.; Seok, D.; Jung, Y.; Lee, K. Hydrophilic Surface Treatment of Carbon Powder Using $\mathrm{CO}_{2}$ Plasma Activated Gas. Coatings 2021, 11, 925. [CrossRef]

19. Yamada, S.; Yassin, M.A.; Weigel, T.; Schmitz, T.; Hansmann, J.; Mustafa, K. Surface activation with oxygen plasma promotes osteogenesis with enhanced extracellular matrix formation in three-dimensional microporous scaffolds. J. Biomed. Mater. Res. Part A 2021, 109, 1560-1574. [CrossRef]

20. Kim, H.G.; Kim, Y.-S.; Kuk, Y.-S.; Kwac, L.K.; Choi, S.-H.; Park, J.; Shin, H.K. Preparation and Characterization of Carbon Fibers from Lyocell Precursors Grafted with Polyacrylamide via Electron-Beam Irradiation. Molecules 2021, 26, 2459. [CrossRef]

21. Gatto, M.L.; Groppo, R.; Bloise, N.; Fassina, L.; Visai, L.; Galati, M.; Iuliano, L.; Mengucci, P. Topological, Mechanical and Biological Properties of Ti6Al4V Scaffolds for Bone Tissue Regeneration Fabricated with Reused Powders via Electron Beam Melting. Materials 2021, 14, 224. [CrossRef] [PubMed] 
22. Szustakiewicz, K.; Kryszak, B.; Dzienny, P.; Poźniak, B.; Tikhomirov, M.; Hoppe, V.; Szymczyk-Ziółkowska, P.; Tylus, W.; Grzymajło, M.; Gadomska-Gajadhur, A.; et al. Cytotoxicity Study of UV-Laser-Irradiated PLLA Surfaces Subjected to BioCeramisation: A New Way towards Implant Surface Modification. Int. J. Mol. Sci. 2021, 22, 8436. [CrossRef]

23. Arroyo-Lamas, N.; Arteagoitia, I.; Ugalde, U. Surface Activation of Titanium Dental Implants by Using UVC-LED Irradiation. Int. J. Mol. Sci. 2021, 22, 2597. [CrossRef] [PubMed]

24. Gabardo, R.S.; de Carvalho Cotre, D.S.; Arias, M.J.L.; Moisés, M.P.; Ferreira, B.T.M.; Samulewski, R.B.; Hinestroza, J.P.; Bezerra, F.M. Surface Modification of Polyester Fabrics by Ozone and Its Effect on Coloration Using Disperse Dyes. Materials 2021, 14, 3492. [CrossRef] [PubMed]

25. Liu, Y.; Liu, Z.; Gao, Y.; Gao, W.; Hou, Z.; Zhu, Y. Facile Method for Surface-Grafted Chitooligosaccharide on Medical Segmented Poly(ester-urethane) Film to Improve Surface Biocompatibility. Membranes 2021, 11, 37. [CrossRef]

26. Chen, J.-C.; Chen, C.-H.; Chang, K.-C.; Liu, S.-M.; Ko, C.-L.; Shih, C.-J.; Sun, Y.-S.; Chen, W.-C. Evaluation of the Grafting Efficacy of Active Biomolecules of Phosphatidylcholine and Type I Collagen on Polyether Ether Ketone: In Vitro and In Vivo. Polymers 2021, 13, 2081. [CrossRef] [PubMed]

27. Díez-Pascual, A.M. Chemical Functionalization of Carbon Nanotubes with Polymers: A Brief Overview. Macromolecules 2021, 1, 64-83. [CrossRef]

28. Mohamed, M.G.; Tsai, M.-Y.; Wang, C.-F.; Huang, C.-F.; Danko, M.; Dai, L.; Chen, T.; Kuo, S.-W. Multifunctional Polyhedral Oligomeric Silsesquioxane (POSS) Based Hybrid Porous Materials for $\mathrm{CO}_{2}$ Uptake and Iodine Adsorption. Polymers 2021, $13,221$. [CrossRef]

29. Khan, M.A.; Govindasamy, R.; Ahmad, A.; Siddiqui, M.R.; Alshareef, S.A.; Hakami, A.A.H.; Rafatullah, M. Carbon Based Polymeric Nanocomposites for Dye Adsorption: Synthesis, Characterization, and Application. Polymers 2021, 13, 419. [CrossRef]

30. Pereira, A.M.; Gomes, D.; da Costa, A.; Dias, S.C.; Casal, M.; Machado, R. Protein-Engineered Polymers Functionalized with Antimicrobial Peptides for the Development of Active Surfaces. Appl. Sci. 2021, 11, 5352. [CrossRef]

31. Charoensri, K.; Rodwihok, C.; Wongratanaphisan, D.; Ko, J.A.; Chung, J.S.; Park, H.J. Investigation of Functionalized Surface Charges of Thermoplastic Starch/Zinc Oxide Nanocomposite Films Using Polyaniline: The Potential of Improved Antibacterial Properties. Polymers 2021, 13, 425. [CrossRef] [PubMed]

32. Brun, P.; Zamuner, A.; Battocchio, C.; Cassari, L.; Todesco, M.; Graziani, V.; Iucci, G.; Marsotto, M.; Tortora, L.; Secchi, V.; et al. Bio-Functionalized Chitosan for Bone Tissue Engineering. Int. J. Mol. Sci. 2021, 22, 5916. [CrossRef]

33. Jhaveri, J.; Raichura, Z.; Khan, T.; Momin, M.; Omri, A. Chitosan Nanoparticles-Insight into Properties, Functionalization and Applications in Drug Delivery and Theranostics. Molecules 2021, 26, 272. [CrossRef]

34. Beagan, A.M.; Alghamdi, A.A.; Lahmadi, S.S.; Halwani, M.A.; Almeataq, M.S.; Alhazaa, A.N.; Alotaibi, K.M.; Alswieleh, A.M. Folic Acid-Terminated Poly(2-Diethyl Amino Ethyl Methacrylate) Brush-Gated Magnetic Mesoporous Nanoparticles as a Smart Drug Delivery System. Polymers 2021, 13, 59. [CrossRef]

35. Donoso-González, O.; Lodeiro, L.; Aliaga, Á.E.; Laguna-Bercero, M.A.; Bollo, S.; Kogan, M.J.; Yutronic, N.; Sierpe, R. Functionalization of Gold Nanostars with Cationic $\beta$-Cyclodextrin-Based Polymer for Drug Co-Loading and SERS Monitoring. Pharmaceutics 2021, 13, 261. [CrossRef] [PubMed]

36. Deyab, M.A.; El Bali, B.; Mohsen, Q.; Essehli, R. Design new epoxy nanocomposite coatings based on metal vanadium oxyphosphate $\mathrm{M}_{0.5} \mathrm{VOPO}_{4}$ for anti-corrosion applications. Sci. Rep. 2021, 11, 8182. [CrossRef]

37. Platnieks, O.; Gaidukovs, S.; Barkane, A.; Gaidukova, G.; Grase, L.; Thakur, V.K.; Filipova, I.; Fridrihsone, V.; Skute, M.; Laka, M. Highly Loaded Cellulose/Poly (butylene succinate) Sustainable Composites for Woody-Like Advanced Materials Application. Molecules 2020, 25, 121. [CrossRef]

38. Saska, S.; Pilatti, L.; Blay, A.; Shibli, J.A. Bioresorbable Polymers: Advanced Materials and 4D Printing for Tissue Engineering. Polymers 2021, 13, 563. [CrossRef]

39. Khalid, M.Y.; Imran, R.; Arif, Z.U.; Akram, N.; Arshad, H.; Al Rashid, A.; Márquez, F.P.G. Developments in Chemical Treatments, Manufacturing Techniques and Potential Applications of Natural-Fibers-Based Biodegradable Composites. Coatings 2021, 11, 293. [CrossRef]

40. Liu, Y.; Lin, T.; Cheng, C.; Wang, Q.; Lin, S.; Liu, C.; Han, X. Research Progress on Synthesis and Application of Cyclodextrin Polymers. Molecules 2021, 26, 1090. [CrossRef]

41. Suriani, M.J.; Zainudin, H.A.; Ilyas, R.A.; Petrů, M.; Sapuan, S.M.; Ruzaidi, C.M.; Mustapha, R. Kenaf Fiber/Pet Yarn Reinforced Epoxy Hybrid Polymer Composites: Morphological, Tensile, and Flammability Properties. Polymers 2021, 13, 1532. [CrossRef] [PubMed]

42. Hassan, R.; Khan, M.U.A.; Abdullah, A.M.; Razak, S.I.A. A Review on Current Trends of Polymers in Orthodontics: BPA-Free and Smart Materials. Polymers 2021, 13, 1409. [CrossRef]

43. Salmi, M. Additive Manufacturing Processes in Medical Applications. Materials 2021, 14, 191. [CrossRef]

44. Saleh Alghamdi, S.; John, S.; Roy Choudhury, N.; Dutta, N.K. Additive Manufacturing of Polymer Materials: Progress, Promise and Challenges. Polymers 2021, 13, 753. [CrossRef] [PubMed]

45. Soares, B.G.; Barra, G.M.O.; Indrusiak, T. Conducting Polymeric Composites Based on Intrinsically Conducting Polymers as Electromagnetic Interference Shielding/Microwave Absorbing Materials-A Review. J. Compos. Sci. 2021, 5, 173. [CrossRef]

46. Duburg, J.C.; Azizi, K.; Primdahl, S.; Hjuler, H.A.; Zanzola, E.; Schmidt, T.J.; Gubler, L. Composite Polybenzimidazole Membrane with High Capacity Retention for Vanadium Redox Flow Batteries. Molecules 2021, 26, 1679. [CrossRef] 
47. Sánchez-Vergara, M.E.; Hamui, L.; Gómez, E.; Chans, G.M.; Galván-Hidalgo, J.M. Design of Promising Heptacoordinated Organotin (IV) Complexes-PEDOT: PSS-Based Composite for New-Generation Optoelectronic Devices Applications. Polymers 2021, 13, 1023. [CrossRef]

48. Azizighannad, S.; Wang, Z.; Siddiqui, Z.; Kumar, V.; Mitra, S. Nano Carbon Doped Polyacrylamide Gel Electrolytes for High Performance Supercapacitors. Molecules 2021, 26, 2631. [CrossRef]

49. Sung, Y.-S.; Lin, L.-Y. Systematic Design of Polypyrrole/Carbon Fiber Electrodes for Efficient Flexible Fiber-Type Solid-State Supercapacitors. Nanomaterials 2020, 10, 248. [CrossRef] [PubMed]

50. Deepali, K.; Sapana, J.; Rizwan, A.; Shagufta, J. Functionalization of conducting polymers and their applications in optoelectronics. Polym.-Plast. Technol. Mater. 2021, 60, 465-487. [CrossRef]

51. Aziz, S.B.; Nofal, M.M.; Kadir, M.F.Z.; Dannoun, E.M.A.; Brza, M.A.; Hadi, J.M.; Abdullah, R.M. Bio-Based Plasticized PVA Based Polymer Blend Electrolytes for Energy Storage EDLC Devices: Ion Transport Parameters and Electrochemical Properties. Materials 2021, 14, 1994. [CrossRef] [PubMed]

52. Begum, B.; Bilal, S.; Shah, A.u.H.A.; Röse, P. Physical, Chemical, and Electrochemical Properties of Redox-Responsive Polybenzopyrrole as Electrode Material for Faradaic Energy Storage. Polymers 2021, 13, 2883. [CrossRef]

53. Aziz, S.B.; Nofal, M.M.; Abdulwahid, R.T.; Ghareeb, H.O.; Dannoun, E.M.A.; Abdullah, R.M.; Hamsan, M.H.; Kadir, M.F.Z. Plasticized Sodium-Ion Conducting PVA Based Polymer Electrolyte for Electrochemical Energy Storage-EEC Modeling, Transport Properties, and Charge-Discharge Characteristics. Polymers 2021, 13, 803. [CrossRef]

54. Sharma, S.; Sudhakara, P.; Omran, A.A.B.; Singh, J.; Ilyas, R.A. Recent Trends and Developments in Conducting Polymer Nanocomposites for Multifunctional Applications. Polymers 2021, 13, 2898. [CrossRef] [PubMed]

55. Rahman, S.U.; Röse, P.; Shah, A.U.H.A.; Krewer, U.; Bilal, S.; Farooq, S. Exploring the Functional Properties of Sodium Phytate Doped Polyaniline Nanofibers Modified FTO Electrodes for High-Performance Binder Free Symmetric Supercapacitors. Polymers 2021, 13, 2329. [CrossRef]

56. Wang, Y.; Wei, H.; Lu, Y.; Wei, S.; Wujcik, E.K.; Guo, Z. Multifunctional Carbon Nanostructures for Advanced Energy Storage Applications. Nanomaterials 2015, 5, 755-777. [CrossRef]

57. Kausar, A. Green Nanocomposites for Energy Storage. J. Compos. Sci. 2021, 5, 202. [CrossRef]

58. Siwal, S.S.; Zhang, Q.; Devi, N.; Thakur, V.K. Carbon-Based Polymer Nanocomposite for High-Performance Energy Storage Applications. Polymers 2020, 12, 505. [CrossRef]

59. Yang, S.; An, X.; Qian, X. Integrated Conductive Hybrid Electrode Materials Based on PPy@ZIF-67-Derived Oxyhydroxide@CFs Composites for Energy Storage. Polymers 2021, 13, 1082. [CrossRef]

60. Bi, X.; Yang, L.; Wang, Z.; Zhan, Y.; Wang, S.; Zhang, C.; Li, Y.; Miao, Y.; Zha, J. Construction of a Three-Dimensional BaTiO 3 Network for Enhanced Permittivity and Energy Storage of PVDF Composites. Materials 2021, 14, 3585. [CrossRef]

61. Kondratiev, V.V.; Holze, R. Intrinsically conducting polymers and their combinations with redox-active molecules for rechargeable battery electrodes: An update. Chem. Pap. 2021, 75, 4981-5007. [CrossRef]

62. Meng, N.; Lian, F.; Cui, G. Macromolecular Design of Lithium Conductive Polymer as Electrolyte for Solid-State Lithium Batteries. Small 2021, 17, 2005762. [CrossRef]

63. Zhu, J.; Zhang, Z.; Zhao, S.; Westover, A.S.; Belharouak, I.; Cao, P. Single-Ion Conducting Polymer Electrolytes for Solid-State Lithium-Metal Batteries: Design, Performance, and Challenges. Adv. Energy Mater. 2021, 11, 2003836. [CrossRef]

64. Yu, L.M.; Man, J.X.; Chen, T.; Luo, D.; Wang, J.; Yang, H.; Zhao, Y.B.; Wang, H.; Yang, Y.; Lu, Z.H. Colorful conducting polymers for vivid solar panels. Nano Energy 2021, 85, 105937. [CrossRef]

65. Chae, J.E.; Lee, S.Y.; Yoo, S.J.; Kim, J.Y.; Jang, J.H.; Park, H.-Y.; Park, H.S.; Seo, B.; Henkensmeier, D.; Song, K.H.; et al. PolystyreneBased Hydroxide-Ion-Conducting Ionomer: Binder Characteristics and Performance in Anion-Exchange Membrane Fuel Cells. Polymers 2021, 13, 690. [CrossRef]

66. Zhou, Z.; Zholobko, O.; Wu, X.-F.; Aulich, T.; Thakare, J.; Hurley, J. Polybenzimidazole-Based Polymer Electrolyte Membranes for High-Temperature Fuel Cells: Current Status and Prospects. Energies 2021, 14, 135. [CrossRef]

67. Tan, S.; Li, J.; Zhou, L.; Chen, P.; Shi, J.; Xu, Z. Modified Carbon Fiber Paper-Based Electrodes Wrapped by Conducting Polymers with Enhanced Electrochemical Performance for Supercapacitors. Polymers 2018, 10, 1072. [CrossRef]

68. Ruano, G.; Molina, B.G.; Torras, J.; Alemán, C. Free-Standing, Flexible Nanofeatured Polymeric Films Prepared by Spin-Coating and Anodic Polymerization as Electrodes for Supercapacitors. Molecules 2021, 26, 4345. [CrossRef] [PubMed]

69. Stempien, Z.; Khalid, M.; Kozanecki, M.; Filipczak, P.; Wrzesińska, A.; Korzeniewska, E.; Sąsiadek, E. Inkjet Printing of Polypyrrole Electroconductive Layers Based on Direct Inks Freezing and Their Use in Textile Solid-State Supercapacitors. Materials 2021, 14, 3577. [CrossRef] [PubMed]

70. Chen, W.; Liu, S.; Guo, L.; Zhang, G.; Zhang, H.; Cao, M.; Wu, L.; Xiang, T.; Peng, Y. A Self-Healing Ionic Liquid-Based Ionically Cross-Linked Gel Polymer Electrolyte for Electrochromic Devices. Polymers 2021, 13, 742. [CrossRef] [PubMed]

71. Kuo, C.-W.; Chang, J.-C.; Chang, J.-K.; Huang, S.-W.; Lee, P.-Y.; Wu, T.-Y. Electrodeposited Copolymers Based on 9,9'-(5-Bromo1,3-phenylene)biscarbazole and Dithiophene Derivatives for High-Performance Electrochromic Devices. Polymers 2021, 13, 1136. [CrossRef] [PubMed]

72. Alsultan, M.; Ameen, A.M.; Al-keisy, A.; Swiegers, G.F. Conducting-Polymer Nanocomposites as Synergistic Supports That Accelerate Electro-Catalysis: PEDOT/Nano $\mathrm{Co}_{3} \mathrm{O}_{4} / \mathrm{rGO}$ as a Photo Catalyst of Oxygen Production from Water. J. Compos. Sci. 2021, 5, 245. [CrossRef] 
73. Ramanavicius, S.; Ramanavicius, A. Conducting Polymers in the Design of Biosensors and Biofuel Cells. Polymers 2021, 13, 49. [CrossRef]

74. Shimoga, G.; Palem, R.R.; Choi, D.-S.; Shin, E.-J.; Ganesh, P.-S.; Saratale, G.D.; Saratale, R.G.; Lee, S.-H.; Kim, S.-Y. PolypyrroleBased Metal Nanocomposite Electrode Materials for High-Performance Supercapacitors. Metals 2021, 11, 905. [CrossRef]

75. Yaqoob, A.A.; Ibrahim, M.N.M.; Umar, K.; Bhawani, S.A.; Khan, A.; Asiri, A.M.; Khan, M.R.; Azam, M.; AlAmmari, A.M. Cellulose Derived Graphene/Polyaniline Nanocomposite Anode for Energy Generation and Bioremediation of Toxic Metals via Benthic Microbial Fuel Cells. Polymers 2021, 13, 135. [CrossRef]

76. Ghafoor, U.; Aqeel, A.B.; Zaman, U.K.u.; Zahid, T.; Noman, M.; Ahmad, M.S. Effect of Molybdenum Disulfide on the Performance of Polyaniline Based Counter Electrode for Dye-Sensitized Solar Cell Applications. Energies 2021, 14, 3786. [CrossRef]

77. Noh, S.; Gong, H.Y.; Lee, H.J.; Koh, W.G. Electrically Conductive Micropatterned Polyaniline-Poly(ethylene glycol) Composite Hydrogel. Materials 2021, 14, 308. [CrossRef]

78. Muench, S.; Wild, A.; Friebe, C.; Häupler, B.; Janoschka, T.; Schubert, U.S. Polymer-Based Organic Batteries. Chem. Rev. 2016, 116, 9438-9484. [CrossRef]

79. Jyothibasu, J.P.; Chen, M.-Z.; Tien, Y.-C.; Kuo, C.-C.; Chen, E.-C.; Lin, Y.-C.; Chiang, T.-C.; Lee, R.-H. V $2 \mathrm{O}_{5} /$ Carbon Nanotube/Polypyrrole Based Freestanding Negative Electrodes for High-Performance Supercapacitors. Catalysts 2021, 11, 980. [CrossRef]

80. Hong, X.; Liu, Y.; Li, Y.; Wang, X.; Fu, J.; Wang, X. Application Progress of Polyaniline, Polypyrrole and Polythiophene in Lithium-Sulfur Batteries. Polymers 2020, 12, 331. [CrossRef]

81. Zhu, L.; Lei, A.; Cao, Y.L.; Ai, X.P.; Yang, H.X. An all-organic rechargeable battery using bipolar polyparaphenylene as a redox-active cathode and anode. Chem. Commun. 2013, 49, 567-569. [CrossRef]

82. Seol, M.-L.; Nam, I.; Sadatian, E.; Dutta, N.; Han, J.-W.; Meyyappan, M. Printable Gel Polymer Electrolytes for Solid-State Printed Supercapacitors. Materials 2021, 14, 316. [CrossRef]

83. Nawaz, B.; Ali, G.; Ullah, M.O.; Rehman, S.; Abbas, F. Investigation of the Electrochemical Properties of $\mathrm{Ni}_{0.5} \mathrm{Zn}_{0.5} \mathrm{Fe}_{2} \mathrm{O}_{4}$ as Binder-Based and Binder-Free Electrodes of Supercapacitors. Energies 2021, 14, 3297. [CrossRef]

84. Azimov, F.; Kim, J.; Choi, S.M.; Jung, H.M. Synergistic Effects of $\mathrm{Fe}_{2} \mathrm{O}_{3}$ Nanotube/Polyaniline Composites for an Electrochemical Supercapacitor with Enhanced Capacitance. Nanomaterials 2021, 11, 1557. [CrossRef]

85. Mohamed, M.G.; Ahmed, M.M.M.; Du, W.-T.; Kuo, S.-W. Meso/Microporous Carbons from Conjugated Hyper-Crosslinked Polymers Based on Tetraphenylethene for High-Performance $\mathrm{CO}_{2}$ Capture and Supercapacitor. Molecules 2021, 26, 738. [CrossRef] [PubMed]

86. Bekhoukh, A.; Moulefera, I.; Sabantina, L.; Abdelghani, B. Development, Investigation, and Comparative Study of the Effects of Various Metal Oxides on Optical Electrochemical Properties Using a Doped PANI Matrix. Polymers 2021, 13, 3344. [CrossRef]

87. Cai, X.; Sun, K.; Qiu, Y.; Jiao, X. Recent Advances in Graphene and Conductive Polymer Composites for Supercapacitor Electrodes: A Review. Crystals 2021, 11, 947. [CrossRef]

88. Wang, H.; Qiu, F.; Lu, C.; Zhu, J.; Ke, C.; Han, S.; Zhuang, X. A Terpyridine-Fe ${ }^{2+}$-Based Coordination Polymer Film for On-Chip Micro-Supercapacitor with AC Line-Filtering Performance. Polymers 2021, 13, 1002. [CrossRef]

89. Ruano, G.; Iribarren, J.I.; Pérez-Madrigal, M.M.; Torras, J.; Alemán, C. Electrical and Capacitive Response of Hydrogel Solid-Like Electrolytes for Supercapacitors. Polymers 2021, 13, 1337. [CrossRef]

90. Chen, K.; Zhao, S.; Sun, J.; Zhou, J.; Wang, Y.; Tao, K.; Xiao, X.; Han, L. Enhanced Capacitance Performance by Coupling 2D Conductive Metal-Organic Frameworks and Conducting Polymers for Hybrid Supercapacitors. ACS Appl. Energy Mater. 2021, 4, 9534-9541. [CrossRef]

91. Olean-Oliveira, A.; Brito, G.A.O.; Cardoso, C.X.; Teixeira, M.F.S. Nanocomposite Materials Based on Electrochemically Synthesized Graphene Polymers: Molecular Architecture Strategies for Sensor Applications. Chemosensors 2021, 9, 149. [CrossRef]

92. Díez-Pascual, A.M. Development of Graphene-Based Polymeric Nanocomposites: A Brief Overview. Polymers 2021, 13, 2978. [CrossRef]

93. Gul, H.; Shah, A.-U.-H.A.; Bilal, S. Achieving Ultrahigh Cycling Stability and Extended Potential Window for Supercapacitors through Asymmetric Combination of Conductive Polymer Nanocomposite and Activated Carbon. Polymers 2019, 11, 1678. [CrossRef] [PubMed]

94. Zhong, M.; Chai, L.; Wang, Y.; Di, J. Enhanced efficiency and stability of perovskite solar cell by adding polymer mixture in perovskite photoactive layer. J. Alloy. Compd. 2021, 864, 158793. [CrossRef]

95. Peng, J.; Walter, D.; Ren, Y.; Tebyetekerwa, M.; Wu, Y.; Duong, T.; Lin, Q.; Li, J.; Lu, T.; Mahmud, M.A.; et al. Nanoscale localized contacts for high fill factors in polymer-passivated perovskite solar cells. Science 2021, 371, 390-395. [CrossRef] [PubMed]

96. Han, T.H.; Lee, J.W.; Choi, C.; Tan, S.; Lee, C.; Zhao, Y.; Dai, Z.; De Marco, N.; Lee, S.J.; Bae, S.H.; et al. Perovskite-polymer composite cross-linker approach for highly-stable and efficient perovskite solar cells. Nat. Commun. 2019, 10, 520. [CrossRef] [PubMed]

97. Shaik, S.; Zhou, Z.; Ouyang, Z.; Han, R.; Li, D. Polymer Additive Assisted Fabrication of Compact and Ultra-Smooth Perovskite Thin Films with Fast Lamp Annealing. Energies 2021, 14, 2656. [CrossRef]

98. Bonardd, S.; Moreno-Serna, V.; Kortaberria, G.; Díaz, D.D.; Leiva, A.; Saldías, C. Dipolar Glass Polymers Containing Polarizable Groups as Dielectric Materials for Energy Storage Applications. A Minireview. Polymers 2019, 11, 317. [CrossRef] 
99. Wang, Z.; Wang, X.; Wang, S.; He, J.; Zhang, T.; Wang, J.; Wu, G. Simultaneously Enhanced Thermal Conductivity and Dielectric Breakdown Strength in Sandwich AlN/Epoxy Composites. Nanomaterials 2021, 11, 1898. [CrossRef]

100. Rajalakshmi, N.; Gopalan, R. Recent Trends in Science and Technology of Hydrogen and Polymer Electrolyte Membrane Fuel Cells. Trans. Indian Natl. Acad. Eng. 2021, 6, 189-218. [CrossRef]

101. Chen, Q.; Zhang, G.; Zhang, X.; Sun, C.; Jiao, K.; Wang, Y. Thermal management of polymer electrolyte membrane fuel cells: A review of cooling methods, material properties, and durability. Appl. Energy 2021, 286, 116496. [CrossRef]

102. Shih, K.-Y.; Wei, J.-J.; Tsai, M.-C. One-Step Microwave-Assisted Synthesis of PtNiCo/rGO Electrocatalysts with High Electrochemical Performance for Direct Methanol Fuel Cells. Nanomaterials 2021, 11, 2206. [CrossRef]

103. Cheng, G.; Li, Z.; Ren, S.; Han, D.; Xiao, M.; Wang, S.; Meng, Y. A Robust Composite Proton Exchange Membrane of Sulfonated Poly (Fluorenyl Ether Ketone) with an Electrospun Polyimide Mat for Direct Methanol Fuel Cells Application. Polymers 2021, 13, 523. [CrossRef]

104. Simari, C.; Nicotera, I.; Aricò, A.S.; Baglio, V.; Lufrano, F. New Insights into Properties of Methanol Transport in Sulfonated Polysulfone Composite Membranes for Direct Methanol Fuel Cells. Polymers 2021, 13, 1386. [CrossRef]

105. Sanij, F.D.; Balakrishnan, P.; Leung, P.; Shah, A.; Su, H.; Xu, Q. Advanced Pd-based nanomaterials for electro-catalytic oxygen reduction in fuel cells: A review. Int. J. Hydrog. Energy 2021, 46, 14596-14627. [CrossRef]

106. Wang, R.; Lou, M.; Zhang, J.; Sun, Z.; Li, Z.; Wen, P. ZIF-8@ZIF-67-Derived Co Embedded into Nitrogen-Doped Carbon Nanotube Hollow Porous Carbon Supported Pt as an Efficient Electrocatalyst for Methanol Oxidation. Nanomaterials 2021, $11,2491$. [CrossRef]

107. Kehoe, K.D.; Romeral, L.; Lundy, R.; Morris, M.A.; Lyons, M.G.; Gun'ko, Y.K. One Dimensional AuAg Nanostructures as Anodic Catalysts in the Ethylene Glycol Oxidation. Nanomaterials 2020, 10, 719. [CrossRef]

108. Ferreira, P.; Abreu, B.; Freire, C.; Fernandes, D.M.; Marques, E.F. Nanocomposites Prepared from Carbon Nanotubes and the Transition Metal Dichalcogenides $\mathrm{WS}_{2}$ and $\mathrm{MoS}_{2}$ via Surfactant-Assisted Dispersions as Electrocatalysts for Oxygen Reactions. Materials 2021, 14, 896. [CrossRef]

109. Yaqoob, L.; Noor, T.; Iqbal, N. Recent progress in development of efficient electrocatalyst for methanol oxidation reaction in direct methanol fuel cell. Int. J. Energy Res. 2021, 45, 6550-6583. [CrossRef]

110. Zhang, T.; Pan, J.; Yuan, J. Porous PtIr bimetallic nanotubes with core shell structure for enhanced electrocatalysis on methanol oxidation. Nanotechnology 2021, 32, 365402. [CrossRef]

111. Hu, Y.; Zhao, Z.; Dong, H.; Mikhailova, M.V.; Davarpanah, A. Hybrid Application of Nanoparticles and Polymer in Enhanced Oil Recovery Processes. Polymers 2021, 13, 1414. [CrossRef]

112. Hu, X.; Li, M.; Peng, C.; Davarpanah, A. Hybrid Thermal-Chemical Enhanced Oil Recovery Methods; An Experimental Study for Tight Reservoirs. Symmetry 2020, 12, 947. [CrossRef]

113. Saberi, H.; Esmaeilnezhad, E.; Choi, H.J. Artificial Neural Network to Forecast Enhanced Oil Recovery Using Hydrolyzed Polyacrylamide in Sandstone and Carbonate Reservoirs. Polymers 2021, 13, 2606. [CrossRef]

114. Liang, S.; Liu, Y.; Hu, S.; Shen, A.; Yu, Q.; Yan, H.; Bai, M. Experimental Study on the Physical Performance and Flow Behavior of Decorated Polyacrylamide for Enhanced Oil Recovery. Energies 2019, 12, 562. [CrossRef]

115. Ahsani, T.; Tamsilian, Y.; Rezaei, A. Molecular dynamic simulation and experimental study of wettability alteration by hydrolyzed polyacrylamide for enhanced oil recovery: A new finding for polymer flooding process. J. Pet. Sci. Eng. 2021, 196, 108029. [CrossRef]

116. Mohan, A.; Rao, A.; Vancso, J.; Mugele, F. Towards enhanced oil recovery: Effects of ionic valency and pH on the adsorption of hydrolyzed polyacrylamide at model surfaces using QCM-D. Appl. Surf. Sci. 2021, 560, 149995. [CrossRef]

117. Lu, X.; Cao, B.; Xie, K.; Cao, W.; Liu, Y.; Zhang, Y.; Wang, X.; Zhang, J. Enhanced oil recovery mechanisms of polymer flooding in a heterogeneous oil reservoir. Pet. Explor. Dev. 2021, 48, 169-178. [CrossRef]

118. Han, X.; Li, C.; Pan, F.; Li, Y.; Feng, Y. A comparative study on enhancing oil recovery with partially hydrolyzed polyacrylamide: Emulsion versus powder. Can. J. Chem. Eng. 2021. [CrossRef]

119. Kang, P.S.; Lim, J.S.; Huh, C. Temperature Dependence of the Shear-Thinning Behavior of Partially Hydrolyzed Polyacrylamide Solution for Enhanced Oil Recovery. J. Energy Resour. Technol. 2021, 143, 063002. [CrossRef]

120. Jang, H.Y.; Zhang, K.; Chon, B.H.; Choi, H.J. Enhanced oil recovery performance and viscosity characteristics of polysaccharide xanthan gum solution. J. Ind. Eng. Chem. 2015, 21, 741-745. [CrossRef]

121. Romero-Zerón, L.; Espinosa, C. Advantageous supramolecular system through self-association of xanthan gum/cationic surfactant via $\beta$-cyclodextrin host-guest complexations for Enhanced Oil Recovery Applications. J. Pet. Sci. Eng. 2020, 185, 106644. [CrossRef]

122. Shimaa, M.E.; Elsayed, G.Z.; Walaa, A.E.O. Guar Gum-Based Hydrogels as Potent Green Polymers for Enhanced Oil Recovery in High-Salinity Reservoirs. ACS Omega 2021, 6, 23421-23431.

123. Malmir, P.; Hashemi, A.; Soulgani, B.S. Mechanistic study of the wettability alteration induced by preformed particle gel (PPG) in carbonate reservoirs. J. Mol. Liq. 2021, 328, 115422. [CrossRef]

124. Cao, M.; Cai, Q.; Guo, G.; Guo, H.; Chen, Y.; Zhang, Y. The preparation and displacement performances of a hollow structure microsphere with swelling-deswelling properties for enhanced oil recovery (EOR). Polym. Bull. 2021, 1-5. [CrossRef] 
125. Jamali, A.; Moghbeli, M.R.; Ameli, F.; Roayaie, E.; Karambeigi, M.S. Synthesis and characterization of pH-sensitive poly(acrylamide-co-methylenebisacrylamide-co-acrylic acid) hydrogel microspheres containing silica nanoparticles: Application in enhanced oil recovery processes. J. Appl. Polym. Sci. 2020, 137, 48491. [CrossRef]

126. Riswati, S.S.; Setiati, R.; Kasmungin, S.; Prakoso, S.; Fathaddin, M.T. Sugarcane bagasse for environmentally friendly superabsorbent polymer: Synthesis methods and potential applications in oil industry. IOP Conf. Ser. Earth Environ. Sci. 2021, 819, 012017. [CrossRef]

127. Vallejos, S.; Hernando, E.; Trigo, M.; García, F.C.; García-Valverde, M.; Iturbe, D.; Cabero, M.J.; Quesada, R.; García, J.M. Polymeric chemosensor for the detection and quantification of chloride in human sweat. Application to the diagnosis of cystic fibrosis. J. Mater. Chem. B 2018, 6, 3735-3741. [CrossRef] [PubMed]

128. Choi, Y.J.; Park, H.; Ha, D.H.; Yun, H.S.; Yi, H.G.; Lee, H. 3D Bioprinting of In Vitro Models Using Hydrogel-Based Bioinks. Polymers 2021, 13, 366. [CrossRef]

129. Campbell, S.; Wu, Q.; Yazbeck, J.; Liu, C.; Okhovatian, S.; Radisic, M. Beyond polydimethylsiloxane: Alternative materials for fabrication of organ on a chip devices and microphysiological systems. ACS Biomater. Sci. Eng. 2021, 7, 2880-2899. [CrossRef]

130. Cui, X.; Li, J.; Hartanto, Y.; Durham, M.; Tang, J.; Zhang, H.; Hooper, G.; Lim, K.; Woodfield, T. Advances in Extrusion 3D Bioprinting: A Focus on Multicomponent Hydrogel-Based Bioinks. Adv. Health Mater. 2020, 9, e1901648. [CrossRef]

131. Gebeyehu, A.; Surapaneni, S.K.; Huang, J.; Mondal, A.; Wang, V.Z.; Haruna, N.F.; Bagde, A.; Arthur, P.; Kutlehria, S.; Patel, N.; et al. Polysaccharide hydrogel based 3D printed tumor models for chemotherapeutic drug screening. Sci. Rep. 2021, 11, 372. [CrossRef]

132. Lin, N.Y.C.; Homan, K.A.; Robinson, S.S.; Kolesky, D.B.; Duarte, N.; Moisan, A.; Lewis, J.A. Renal reabsorption in 3D vascularized proximal tubule models. Proc. Natl. Acad. Sci. USA 2019, 116, 5399-5404. [CrossRef]

133. Sun, C.-K.; Ke, C.-J.; Lin, Y.-W.; Lin, F.-H.; Tsai, T.-H.; Sun, J.-S. Transglutaminase Cross-Linked Gelatin-Alginate-Antibacterial Hydrogel as the Drug Delivery-Coatings for Implant-Related Infections. Polymers 2021, 13, 414. [CrossRef]

134. Buxadera-Palomero, J.; Fricke, K.; Reuter, S.; Gil, F.J.; Rodriguez, D.; Canal, C. One-Step Liquid Phase Polymerization of HEMA by Atmospheric-Pressure Plasma Discharges for Ti Dental Implants. Appl. Sci. 2021, 11, 662. [CrossRef]

135. Cornejo-Bravo, J.M.; Palomino, K.; Palomino-Vizcaino, G.; Pérez-Landeros, O.M.; Curiel-Alvarez, M.; Valdez-Salas, B.; Bucio, E.; Magaña, H. Poly(N-vinylcaprolactam) and Salicylic Acid Polymeric Prodrug Grafted onto Medical Silicone to Obtain a Novel Thermo- and pH-Responsive Drug Delivery System for Potential Medical Devices. Materials 2021, 14, 1065. [CrossRef]

136. De Leo, V.; Milano, F.; Agostiano, A.; Catucci, L. Recent Advancements in Polymer/Liposome Assembly for Drug Delivery: From Surface Modifications to Hybrid Vesicles. Polymers 2021, 13, 1027. [CrossRef]

137. Neves, A.R.; Albuquerque, T.; Faria, R.; Paul, M.; Biswas, S.; Sousa, Â.; Costa, D. Development of Tailor-Made Dendrimer Ternary Complexes for Drug/Gene Co-Delivery in Cancer. Pharmaceutics 2021, 13, 1256. [CrossRef]

138. Sun, Y.; Ma, X.; Jing, X.; Hu, H. PAMAM-Functionalized Cellulose Nanocrystals with Needle-Like Morphology for Effective Cancer Treatment. Nanomaterials 2021, 11, 1640. [CrossRef]

139. Tarach, P.; Janaszewska, A. Recent Advances in Preclinical Research Using PAMAM Dendrimers for Cancer Gene Therapy. Int. J. Mol. Sci. 2021, 22, 2912. [CrossRef]

140. Hanurry, E.Y.; Mekonnen, T.W.; Andrgie, A.T.; Darge, H.F.; Birhan, Y.S.; Hsu, W.-H.; Chou, H.-Y.; Cheng, C.-C.; Lai, J.-Y.; Tsai, H.-C. Biotin-Decorated PAMAM G4.5 Dendrimer Nanoparticles to Enhance the Delivery, Anti-Proliferative, and Apoptotic Effects of Chemotherapeutic Drug in Cancer Cells. Pharmaceutics 2020, 12, 443. [CrossRef]

141. Mandal, A.K. Dendrimers in targeted drug delivery applications: A review of diseases and cancer. Int. J. Polym. Mater. Polym. Biomater. 2021, 70, 287-297. [CrossRef]

142. Chittasupho, C.; Anuchapreeda, S.; Sarisuta, N. CXCR4 targeted dendrimer for anti-cancer drug delivery and breast cancer cell migration inhibition. Eur. J. Pharm. Biopharm. 2017, 119, 310-321. [CrossRef] [PubMed]

143. Valente, J.F.A.; Pereira, P.; Sousa, A.; Queiroz, J.A.; Sousa, F. Effect of Plasmid DNA Size on Chitosan or Polyethyleneimine Polyplexes Formulation. Polymers 2021, 13, 793. [CrossRef]

144. Maity, S.; Choudhary, P.; Manjunath, M.; Kulkarni, A.; Murthy, N. A biodegradable adamantane polymer with ketal linkages in its backbone for gene therapy. Chem. Commun. 2015, 51, 1-4. [CrossRef]

145. Wang, Y.; Sun, G.; Gong, Y.; Zhang, Y.; Liang, X.; Yang, L. Functionalized Folate-Modified Graphene Oxide/PEI siRNA Nanocomplexes for Targeted Ovarian Cancer Gene Therapy. Nanoscale Res. Lett. 2020, 15, 1-11. [CrossRef]

146. Gao, S.; Tang, G.; Hua, D.; Xiong, R.; Han, J.; Jiang, S.; Zhang, Q.; Huang, C. Stimuli-responsive bio-based polymeric systems and their applications. J. Mater. Chem. B 2019, 7, 709-729. [CrossRef]

147. Zhang, G.; Yi, H.; Bao, C. Stimuli-Responsive Poly(aspartamide) Derivatives and Their Applications as Drug Carriers. Int. J. Mol. Sci. 2021, 22, 8817. [CrossRef]

148. McCarthy, P.C.; Zhang, Y.; Abebe, F. Recent Applications of Dual-Stimuli Responsive Chitosan Hydrogel Nanocomposites as Drug Delivery Tools. Molecules 2021, 26, 4735. [CrossRef]

149. Atanasova, D.; Staneva, D.; Grabchev, I. Textile Materials Modified with Stimuli-Responsive Drug Carrier for Skin Topical and Transdermal Delivery. Materials 2021, 14, 930. [CrossRef] [PubMed]

150. Qiao, S.; Wang, H. Temperature-responsive polymers: Synthesis, properties, and biomedical applications. Nano Res. 2018, 11, 5400-5423. [CrossRef]

151. Xian, S.; Webber, M.J. Temperature-responsive supramolecular hydrogels. J. Mater. Chem. B 2020, 8, 9197-9211. [CrossRef] 
152. Kotsuchibashi, Y.; Ebara, M.; Aoyagi, T.; Narain, R. Recent Advances in Dual Temperature Responsive Block Copolymers and Their Potential as Biomedical Applications. Polymers 2016, 8, 380. [CrossRef]

153. Nastyshyn, S.; Raczkowska, J.; Stetsyshyn, Y.; Orzechowska, B.; Bernasik, A.; Shymborska, Y.; Brzychczy-Włoch, M.; Gosiewski, T.; Lishchynskyi, O.; Ohar, H.; et al. Non-cytotoxic, temperature-responsive and antibacterial POEGMA based nanocomposite coatings with silver nanoparticles. RSC Adv. 2020, 10, 10155-10166. [CrossRef]

154. Gajos, K.; Szafraniec, K.; Petrou, P.; Budkowski, A. Surface density dependent orientation and immunological recognition of antibody on silicon: TOF-SIMS and surface analysis of two covalent immobilization methods. Appl. Surf. Sci. 2020, 518, 146269. [CrossRef]

155. Raczkowska, J.; Stetsyshyn, Y.; Awsiuk, K.; Brzychczy-Włoch, M.; Gosiewski, T.; Jany, B.; Lishchynskyi, O.; Shymborska, Y.; Nastyshyn, S.; Bernasik, A.; et al. Command surfaces with thermo-switchable antibacterial activity. Mater. Sci. Eng. C 2019, 103, 109806. [CrossRef]

156. Lisuzzo, L.; Cavallaro, G.; Milioto, S.; Lazzara, G. Layered composite based on halloysite and natural polymers: A carrier for pH controlled release of drugs. New J. Chem. 2019, 43, 10887-10893. [CrossRef]

157. Bobrowska, J.A.; Awsiuk, K.; Pabijan, J.; Bobrowski, P.; Lekki, J.; Sowa, K.M.; Rysz, J.; Budkowski, A.; Lekka, M. Biophysical and biochemical characteristics as complementary indicators of melanoma progression. Anal. Chem. 2019, 91, 9885-9892. [CrossRef]

158. Lishchynskyi, O.; Stetsyshyn, Y.; Raczkowska, J.; Awsiuk, K.; Orzechowska, B.; Abalymov, A.; Skirtach, A.G.; Bernasik, A.; Nastyshyn, S.; Budkowski, A. Fabrication and Impact of Fouling-Reducing Temperature-Responsive POEGMA Coatings with Embedded CaCO3 Nanoparticles on Different Cell Lines. Materials 2021, 14, 1417. [CrossRef]

159. Lazzara, G.; Cavallaro, G.; Panchal, A.; Fakhrullin, R.; Stavitskaya, A.; Vinokurov, V.; Lvov, Y. An assembly of organic-inorganic composites using halloysite clay nanotubes. Curr. Opin. Colloid Interface Sci. 2018, 35, 42-50. [CrossRef]

160. Stetsyshyn, Y.; Raczkowska, J.; Harhay, K.; Gajos, K.; Melnyk, Y.; Dąbczyński, P.; Shevtsova, T.; Budkowski, A. Temperatureresponsive and multi-responsive grafted polymer brushes with transitions based on critical solution temperature: Synthesis, properties, and applications. Colloid Polym. Sci. 2021, 299, 363-383. [CrossRef]

161. Park, Y.; Kim, M.; Chung, H.j;; Woo, A.H.; Noda, I.; Jung, Y.M. The Study of pH Effects on Phase Transition of Multi-Stimuli Responsive P(NiPAAm-co-AAc) Hydrogel Using 2D-COS. Polymers 2021, 13, 1447. [CrossRef]

162. Longo, R.; Gorrasi, G.; Guadagno, L. Electromagnetically Stimuli-Responsive Nanoparticles-Based Systems for Biomedical Applications: Recent Advances and Future Perspectives. Nanomaterials 2021, 11, 848. [CrossRef]

163. Andrade, F.; Roca-Melendres, M.M.; Durán-Lara, E.F.; Rafael, D.; Schwartz, S., Jr. Stimuli-Responsive Hydrogels for Cancer Treatment: The Role of $\mathrm{pH}$, Light, Ionic Strength and Magnetic Field. Cancers 2021, 13, 1164. [CrossRef]

164. Chatterjee, S.; Hui, P.C.-1. Review of Applications and Future Prospects of Stimuli-Responsive Hydrogel Based on ThermoResponsive Biopolymers in Drug Delivery Systems. Polymers 2021, 13, 2086. [CrossRef]

165. Alwattar, J.K.; Mneimneh, A.T.; Abla, K.K.; Mehanna, M.M.; Allam, A.N. Smart Stimuli-Responsive Liposomal Nanohybrid Systems: A Critical Review of Theranostic Behavior in Cancer. Pharmaceutics 2021, 13, 355. [CrossRef]

166. Wu, G.; Wang, J.; Liu, Q.; Lu, R.; Wei, Y.; Cheng, F.; Han, J.; Xing, W.; Huang, Y. Surface Permeability of Membrane and Catalytic Performance Based on Redox-Responsive of Hybrid Hollow Polymeric Microcapsules. Molecules 2021, 26, 633. [CrossRef]

167. Turanl1, Y.; Acartürk, F. Fabrication and characterization of budesonide loaded colon-specific nanofiber drug delivery systems using anionic and cationic polymethacrylate polymers. J. Drug Deliv. Sci. Technol. 2021, 63, 102511. [CrossRef]

168. Sengupta, I.; Kumar, S.S.; Gupta, K.; Chakraborty, S. In-vitro Release Study through Novel Graphene Oxide Aided Alginate Based pH-Sensitive Drug Carrier for Gastrointestinal Tract. Mater. Today Commun. 2021, 26, 101737. [CrossRef]

169. Xue, S.; Wu, Y.; Wang, J.; Guo, M.; Liu, D.; Lei, W. Boron Nitride Nanosheets/PNIPAM Hydrogels with Improved ThermoResponsive Performance. Materials 2018, 11, 1069. [CrossRef]

170. Thiele, S.; Andersson, J.; Dahlin, A. Tuning the Thermoresponsive Behavior of Surface-Attached PNIPAM Networks: Varying the Crosslinker Content in SI-ATRP. Langmuir 2021, 11, 3391-3398. [CrossRef]

171. Giaouzi, D.; Pispas, S. Complexation behavior of PNIPAM-b-QPDMAEA copolymer aggregates with linear DNAs of different lengths. Eur. Polym. J. 2021, 155, 110575. [CrossRef]

172. Alqahtani, M.S.; Alqahtani, A.; Al-Thabit, A.; Roni, M.; Syed, R. Novel lignin nanoparticles for oral drug delivery. J. Mater. Chem. B 2019, 7, 4461-4473. [CrossRef]

173. Ni, S. Nanoparticles carrying natural product for drug delivery. J. Drug Deliv. Ther. 2017, 7, 73-75. [CrossRef]

174. Lin, C.H.; Chen, C.H.; Lin, Z.C.; Fang, J.Y. Recent advances in oral delivery of drugs and bioactive natural products using solid lipid nanoparticles as the carriers. J. Food Drug Anal. 2017, 25, 219-234. [CrossRef] [PubMed]

175. Luo, C.F.; Yuan, M.; Chen, M.S.; Liu, S.M.; Zhu, L.; Huang, B.Y.; Liu, X.W.; Xiong, W. Pharmacokinetics, tissue distribution and relative bioavailability of puerarin solid lipid nanoparticles following oral administration. Int. J. Pharm. 2011, 410, 138-144. [CrossRef] [PubMed]

176. Luo, C.F.; Hou, N.; Tian, J.; Yuan, M.; Liu, S.M.; Xiong, L.G.; Luo, J.D.; Chen, M.S. Metabolic profile of puerarin in rats after intragastric administration of puerarin solid lipid nanoparticles. Int. J. Nanomed. 2013, 8, 933-940. [CrossRef]

177. Zhang, C.; Gu, C.; Peng, F.; Liu, W.; Wan, J.; Xu, H.; Lam, C.W.; Yang, X. Preparation and optimization of triptolide-loaded solid lipid nanoparticles for oral delivery with reduced gastric irritation. Molecules 2013, 18, 13340-13356. [CrossRef]

178. Rizwanullah, M.; Zaki, M.A.; Garg, A.; Ahmad, J. Advancement in design of nanostructured lipid carriers for cancer targeting and theranostic application. Biochim. Biophys. Acta (BBA)-Gen. Subj. 2021, 1865, 129936. [CrossRef] [PubMed] 
179. Subramaniam, B.; Arshad, N.M.; Malagobadan, S.; Misran, M.; Nyamathulla, S.; Mun, K.S.; Nagoor, N.H. Development and Evaluation of 1'-Acetoxychavicol Acetate (ACA)-Loaded Nanostructured Lipid Carriers for Prostate Cancer Therapy. Pharmaceutics 2021, 13, 439. [CrossRef]

180. Elmowafy, M.; Al-Sanea, M.M. Nanostructured lipid carriers (NLCs) as drug delivery platform: Advances in formulation and delivery strategies. Saudi Pharm. J. 2021, 29, 999-1012. [CrossRef]

181. Nordin, N.; Yeap, S.K.; Rahman, H.S.; Zamberi, N.R.; Mohamad, N.E.; Abu, N.; Masarudin, M.J.; Abdullah, R.; Alitheen, N.B. Antitumor and Anti-Metastatic Effects of Citral-Loaded Nanostructured Lipid Carrier in 4T1-Induced Breast Cancer Mouse Model. Molecules 2020, 25, 2670. [CrossRef]

182. Ong, Y.S.; Yazan, L.S.; Ng, W.K.; Abdullah, R.; Mustapha, N.M.; Sapuan, S.; Foo, J.B.; Tor, Y.S.; How, C.W.; Abd Rahman, N.; et al. Thymoquinone loaded in nanostructured lipid carrier showed enhanced anticancer activity in $4 \mathrm{~T} 1$ tumor-bearing mice. Nanomedicine 2018, 13, 1567-1582. [CrossRef]

183. Nordin, N.; Yeap, S.K.; Zamberi, N.R.; Abu, N.; Mohamad, N.E.; Rahman, H.S.; How, C.W.; Masarudin, M.J.; Abdullah, R.; Alitheen, N.B. Characterization and toxicity of citral incorporated with nanostructured lipid carrier. PeerJ 2018, 6, e3916. [CrossRef]

184. Rahman, H.S.; Rasedee, A.; Abdul, A.B.; Zeenathul, N.A.; Othman, H.H.; Yeap, S.K.; How, C.W.; Hafiza, W.A.G.W.N. Zerumboneloaded nanostructured lipid carrier induces G2/M cell cycle arrest and apoptosis via mitochondrial pathway in a human lymphoblastic leukemia cell line. Int. J. Nanomed. 2014, 9, 527-538. [CrossRef]

185. Butowska, K.; Woziwodzka, A.; Borowik, A.; Piosik, J. Polymeric Nanocarriers: A Transformation in Doxorubicin Therapies. Materials 2021, 14, 2135. [CrossRef]

186. Mulvihill, J.J.; Cunnane, E.M.; Ross, A.M.; Duskey, J.T.; Tosi, G.; Grabrucker, A.M. Drug delivery across the blood-brain barrier: Recent advances in the use of nanocarriers. Nanomedicine 2020, 15, 205-214. [CrossRef]

187. Oddone, N.; Pederzoli, F.; Duskey, J.T.; De Benedictis, C.A.; Grabrucker, A.M.; Forni, F.; Vandelli, M.A.; Ruozi, B.; Tosi, G. ROS-responsive "smart" polymeric conjugate: Synthesis, characterization and proof-of-concept study. Int. J. Pharm. 2019, 570, 118655. [CrossRef]

188. Zhu, F.D.; Hu, Y.J.; Yu, L.; Zhou, X.G.; Wu, J.M.; Tang, Y.; Qin, D.L.; Fan, Q.Z.; Wu, A.G. Nanoparticles: A Hope for the Treatment of Inflammation in CNS. Front. Pharmacol. 2021, 12, 683935. [CrossRef]

189. Gupta, J.; Fatima, M.T.; Islam, Z.; Khan, R.H.; Uversky, V.N.; Salahuddin, P. Nanoparticle formulations in the diagnosis and therapy of Alzheimer's disease. Int. J. Biol. Macromol. 2019, 130, 515-526. [CrossRef]

190. Boridy, S.; Takahashi, H.; Akiyoshi, K.; Maysinger, D. The binding of pullulan modified cholesteryl nanogels to Abeta oligomers and their suppression of cytotoxicity. Biomaterials 2009, 30, 5583-5591. [CrossRef] [PubMed]

191. Rajan, R.; Ahmed, S.; Sharma, N.; Kumar, N.; Debas, A.; Matsumura, K. Review of the current state of protein aggregation inhibition from a materials chemistry perspective: Special focus on polymeric materials. Mater. Adv. 2021, 2, 1139-1176. [CrossRef]

192. Cano, A.; Sánchez-López, E.; Ettcheto, M. Current advances in the development of novel polymeric nanoparticles for the treatment of neurodegenerative diseases. Nanomedecine 2020, 15, 1239-1261. [CrossRef]

193. Bittner, A.; Gosselet, F.; Sevin, E.; Dehouck, L.; Ducray, A.D.; Gaschen, V.; Stoffel, M.H.; Cho, H.; Mevissen, M. Time-Dependent Internalization of Polymer-Coated Silica Nanoparticles in Brain Endothelial Cells and Morphological and Functional Effects on the Blood-Brain Barrier. Int. J. Mol. Sci. 2021, 22, 1657. [CrossRef]

194. Chan, M.H.; Chen, W.; Li, C.H.; Fang, C.Y.; Chang, Y.C.; Wei, D.H.; Liu, R.S.; Hsiao, M. An Advanced In Situ Magnetic Resonance Imaging and Ultrasonic Theranostics Nanocomposite Platform: Crossing the Blood-Brain Barrier and Improving the Suppression of Glioblastoma Using Iron-Platinum Nanoparticles in Nanobubbles. ACS Appl. Mater. Interfaces 2021, 13, 26759-26769. [CrossRef]

195. El-Ghoul, Y.; Alminderej, F.M. Bioactive and superabsorbent cellulosic dressing grafted alginate and Carthamus tinctorius polysaccharide extract for the treatment of chronic wounds. Text. Res. J. 2021, 91, 235-248. [CrossRef]

196. El-Ghoul, Y. Biological and microbiological performance of new polymer-based chitosan and synthesized aminocyclodextrin finished polypropylene abdominal wall prosthesis biomaterial. Text. Res. J. 2020, 90, 2690-2702. [CrossRef]

197. Alminderej, M.F.; El-Ghoul, Y. Synthesis and study of a new biopolymer-based chitosan/hematoxylin grafted to cotton wound dressings. J. Appl. Polym. Sci. 2019, 136, 47625. [CrossRef]

198. Salah, F.; El Ghoul, Y.; Alminderej, F.M.; El-Golli-Bennour, E.; Ouanes, Z.; Maciejak, O.; Jarroux, N.; Majdoub, H.; Sakli, F. Development, characterization, and biological assessment of biocompatible cellulosic wound dressing grafted Aloe vera bioactive polysaccharide. Cellulose 2019, 26, 4957-4970. [CrossRef]

199. Salah, F.; El-Ghoul, Y.; Mahdhi, A.; Majdoub, H.; Jarroux, N.; Sakli, F. Effect of the deacetylation degree on the antibacterial and antibiofilm activity of acemannan from Aloe vera. Ind. Crop. Prod. 2017, 103, 13-18. [CrossRef]

200. El-Ghoul, Y.; Salah, F.; Majdoub, H.; Sakli, F. Synthesis and study of drug delivery system obtained via $\beta$-cyclodextrin functionalization of viscose/polyester dressings. J. Ind. Text. 2017, 47, 489-504. [CrossRef]

201. El-Ghoul, Y.; Ammar, C.; El-Achari, A. New polymer based modified cyclodextrins grafted to textile fibers; characterization and application to cotton wound dressings. Int. J. Appl. Res. Text. 2014, 2, 11-21.

202. Ammar, C.; El Ghoul, Y.; El Achari, A. Finishing of polypropylene fibers with cyclodextrins and polyacrylic acid as a crosslinking agent. Text. Res. J. 2015, 85, 171-179. [CrossRef] 
203. El Ghoul, Y.; Blanchemain, N.; Laurent, T.; Campagne, C.; El Achari, A.; Roudesli, S.; Morcellet, M.; Martel, B.; Hildebrand, H.F. Chemical, biological and microbiological evaluation of cyclodextrin finished polyamide inguinal meshes. Acta Biomater. 2008, 4, 1392-1400. [CrossRef]

204. Alminderej, F. Study of new cellulosic dressing with enhanced antibacterial performance grafted with a biopolymer of chitosan and myrrh polysaccharide extract. Arab. J. Chem. 2020, 13, 3672-3681. [CrossRef]

205. Salah, F.; El-Ghoul, Y.; Roudesli, S. Bacteriological effects of functionalized cotton dressings. J. Text. Inst. 2016, 107, 171-181. [CrossRef]

206. Alminderej, F.M.; Ammar, C.; El-Ghoul, Y. Functionalization, characterization and microbiological performance of new biocompatible cellulosic dressing grafted chitosan and Suaeda fruticosa polysaccharide extract. Cellulose 2021, 28, 9821-9835. [CrossRef]

207. Shen, S.; Chen, X.; Shen, Z.; Chen, H. Marine Polysaccharides for Wound Dressings Application: An Overview. Pharmaceutics 2021, 13, 1666. [CrossRef]

208. Mokhtari, H.; Tavakoli, S.; Safarpour, F.; Kharaziha, M.; Bakhsheshi-Rad, H.R.; Ramakrishna, S.; Berto, F. Recent Advances in Chemically-Modified and Hybrid Carrageenan-Based Platforms for Drug Delivery, Wound Healing, and Tissue Engineering. Polymers 2021, 13, 1744. [CrossRef]

209. Jung, H.S.; Kim, M.H.; Shin, J.Y.; Park, S.R.; Jung, J.Y.; Park, W.H. Electrospinning and wound healing activity of $\beta$-chitin extracted from cuttlefish bone. Carbohydr. Polym. 2018, 193, 205-211. [CrossRef]

210. Moradkhannejhad, L.; Abdouss, M.; Nikfarjam, N.; Mazinani, S.; Heydari, V. Electrospinning of zein/propolis nanofibers; antimicrobial properties and morphology investigation. J. Mater. Sci. Mater. Med. 2018, 29, 165. [CrossRef]

211. D'Amato, A.R.; Puhl, D.L.; Ellman, S.A.T.; Balouch, B.; Gilbert, R.J.; Palermo, E.F. Vastly extended drug release from poly(pro-17$\beta$-estradiol) materials facilitates in vitro neurotrophism and neuroprotection. Nat. Commun. 2019, 10, 4830. [CrossRef]

212. Cleeton, C.; Keirouz, A.; Chen, X.; Radacsi, N. Electrospun Nanofibers for Drug Delivery and Biosensing. ACS Biomater. Sci. Eng. 2019, 5, 4183-4205. [CrossRef]

213. Chen, S.; Li, R.; Li, X.; Xie, J. Electrospinning: An Enabling Nanotechnology Platform for Drug Delivery and Regenerative Medicine. Adv. Drug Deliv. Rev. 2018, 132, 188-213. [CrossRef]

214. Horne, J.; McLoughlin, L.; Bridgers, B.; Wujcik, E.K. Recent Developments in Nanofiber-Based Sensors for Disease Detection, Immunosensing, and Monitoring. Sens. Actuators Rep. 2020, 2, 100005. [CrossRef]

215. Yang, T.; Zhan, L.; Huang, C.Z. Recent Insights into Functionalized Electrospun Nanofibrous Films for Chemo-/Bio-Sensors. TrAC Trends Anal. Chem. 2020, 124, 115813. [CrossRef]

216. Liu, S.H.; Zhang, H.G.; Hu, Q.X.; Wang, B.; Li, S.; Zhang, C. Development and Evaluation of Biomimetic 3D Coated Composite Scaffold for Application as Skin Substitutes. Macromol. Mater. Eng. 2020, 305, 1900848. [CrossRef]

217. Yang, X.P.; Li, L.F.; Yang, D.Z.; Nie, J.; Ma, G.P. Electrospun Core-Shell Fibrous 2D Scaffold with Biocompatible Poly(Glycerol Sebacate) and Poly-L-Lactic Acid for Wound Healing. Adv. Fiber Mater. 2020, 2, 105-117. [CrossRef]

218. Huang, R.; Chen, X.; Dong, Y.; Zhang, X.; Wei, Y.; Yang, Z.; Li, W.; Guo, Y.; Liu, J.; Yang, Z.; et al. MXene Composite Nanofibers for Cell Culture and Tissue Engineering. ACS Appl. Bio Mater. 2020, 3, 2125-2131. [CrossRef]

219. Li, X.; Zhang, C.; Haggerty, A.E.; Yan, J.; Lan, M.; Seu, M.; Yang, M.; Marlow, M.M.; Maldonado-Lasunción, I.; Cho, B.; et al. The Effect of a Nanofiber-Hydrogel Composite on Neural Tissue Repair and Regeneration in the Contused Spinal Cord. Biomaterials 2020, 245, 119978. [CrossRef]

220. Homaeigohar, S.; Boccaccini, A.R. Antibacterial Biohybrid Nanofibers for Wound Dressings. Acta Biomater. 2020, 107, 25-49. [CrossRef]

221. Lv, D.; Zhu, M.M.; Jiang, Z.C.; Jiang, S.H.; Zhang, Q.L.; Xiong, R.H.; Huang, C.B. Green Electrospun Nanofibers and Their Application in Air Filtration. Macromol. Mater. Eng. 2018, 303, 1800336. [CrossRef]

222. Ding, X.X.; Li, Y.Y.; Si, Y.; Yin, X.; Yu, J.Y.; Ding, B. Electrospun polyvinylidene fluoride/SiO2 nanofibrous membranes with enhanced electret property for efficient air filtration. Chem. Commun. 2019, 13, 57-62. [CrossRef]

223. Birhanu, G.; Tanha, S.; Javar, H.A.; Seyedjafari, E.; Zandi-Karimi, A.; Dehkordi, B.K. Dexamethasone Loaded Multi-Layer Poly-L-Lactic Acid/Pluronic P123 Composite Electrospun Nanofiber Scaffolds for Bone Tissue Engineering and Drug Delivery. Pharm. Dev. Technol. 2019, 24, 338-347. [CrossRef]

224. Chan, A.H.P.; Filipe, E.C.; Tan, R.P.; Miguel, S.; Yang, N.J.; Hung, J.; Feng, J.Y.; Nazir, S.; Benn, J.A.; Ng, C.K.M.; et al. Altered processing enhances the efficacy of small-diameter silk fibroin vascular grafts. Sci. Rep. 2019, 9, 17461. [CrossRef]

225. Nagiah, N.; Murdock, C.J.; Bhattacharjee, M.; Nair, L.; Laurencin, C.T. Development of Tripolymeric Triaxial Electrospun Fibrous Matrices for Dual Drug Delivery Applications. Sci. Rep. 2020, 10, 609. [CrossRef]

226. Dos Santos, D.M.; Chagas, P.A.M.; Leite, I.S.; Inada, N.M.; de Annunzio, S.R.; Fontana, C.R.; Campana-Filho, S.P.; Correa, D.S. Core-Sheath Nanostructured Chitosan-Based Nonwovens as a Potential Drug Delivery System for Periodontitis Treatment. Int. J. Biol. Macromol. 2020, 142, 521-534. [CrossRef]

227. Yang, J.; Wang, K.; Yu, D.-G.; Yang, Y.; Bligh, S.W.A.; Williams, G.R. Electrospun Janus Nanofibers Loaded with a Drug and Inorganic Nanoparticles as an Effective Antibacterial Wound Dressing. Mater. Sci. Eng. C 2020, 111, 110805. [CrossRef]

228. Niiyama, E.; Uto, K.; Lee, C.M.; Sakura, K.; Ebara, M. Hyperthermia Nanofiber Platform Synergized by Sustained Release of Paclitaxel to Improve Antitumor Efficiency. Adv. Health Mater. 2019, 8, 1900102. [CrossRef] 
229. Altinbasak, I.; Jijie, R.; Barras, A.; Golba, B.; Sanyal, R.; Bouckaert, J.; Drider, D.; Bilyy, R.; Dumych, T.; Paryzhak, S.; et al. Reduced Graphene-Oxide-Embedded Polymeric Nanofiber Mats: An "on-Demand" Photothermally Triggered Antibiotic Release Platform. ACS Appl. Mater. Interfaces 2018, 10, 41098-41106. [CrossRef]

230. Pinese, C.; Lin, J.; Milbreta, U.; Li, M.; Wang, Y.; Leong, K.W.; Chew, S.Y. Sustained Delivery of SiRNA/Mesoporous Silica Nanoparticle Complexes from Nanofiber Scaffolds for Long-Term Gene Silencing. Acta Biomater. 2018, 76, 164-177. [CrossRef]

231. Baek, J.; Lee, E.; Lotz, M.K.; D'Lima, D.D. Bioactive Proteins Delivery through Core-Shell Nanofibers for Meniscal Tissue Regeneration. Nanomed. Nanotechnol. Biol. Med. 2020, 23, 102090. [CrossRef]

232. Li, J.; Xu, W.; Li, D.; Liu, T.; Zhang, Y.S.; Ding, J.; Chen, X. Locally Deployable Nanofiber Patch for Sequential Drug Delivery in Treatment of Primary and Advanced Orthotopic Hepatomas. ACS Nano 2018, 12, 6685-6699. [CrossRef]

233. Yu, D.G.; Li, X.Y.; Wang, X.; Yang, J.H.; Bligh, S.W.A.; Williams, G.R. Nanofibers Fabricated Using Triaxial Electrospinning as Zero Order Drug Delivery Systems. ACS Appl. Mater. Interfaces 2015, 7, 18891-18897. [CrossRef]

234. Kuang, G.; Zhang, Z.; Liu, S.; Zhou, D.; Lu, X.; Jing, X.; Huang, Y. Biphasic Drug Release from Electrospun Polyblend Nanofibers for Optimized Local Cancer Treatment. Biomater. Sci. 2018, 6, 324-331. [CrossRef]

235. Bonani, W.; Motta, A.; Migliaresi, C.; Tan, W. Biomolecule Gradient in Micropatterned Nanofibrous Scaffold for Spatiotemporal Release. Langmuir 2012, 28, 13675-13687. [CrossRef]

236. Qu, M.; Jiang, X.; Zhou, X.; Wang, C.; Wu, Q.; Ren, L.; Zhu, J.; Zhu, S.; Tebon, P.; Sun, W.; et al. Stimuli-Responsive Delivery of Growth Factors for Tissue Engineering. Adv. Health Mater. 2020, 9, 1901714. [CrossRef]

237. Li, F.; Qin, Y.; Lee, J.; Liao, H.; Wang, N.; Davis, T.P.; Qiao, R.; Ling, D. Stimuli-responsive nano-assemblies for remotely controlled drug delivery. J. Control. Release 2020, 322, 566-592. [CrossRef]

238. Ballesteros, C.A.S.; Correa, D.S.; Zucolotto, V. Polycaprolactone Nanofiber Mats Decorated with Photoresponsive Nanogels and Silver Nanoparticles: Slow Release for Antibacterial Control. Mater. Sci. Eng. C 2020, 107, 110334. [CrossRef]

239. Singh, B.; Shukla, N.; Kim, J.; Kim, K.; Park, M.-H. Stimuli-Responsive Nanofibers Containing Gold Nanorods for On-Demand Drug Delivery Platforms. Pharmaceutics 2021, 13, 1319. [CrossRef]

240. Mamidi, N.; Zuníga, A.E.; Villela-Castrejón, J. Engineering and Evaluation of Forcespun Functionalized Carbon Nano-Onions Reinforced Poly (ع-Caprolactone) Composite Nanofibers for PH-Responsive Drug Release. Mater. Sci. Eng. C 2020, 112, 110928. [CrossRef]

241. Banimohamad-Shotorbani, B.; Rahmani Del Bakhshayesh, A.; Mehdipour, A.; Jarolmasjed, S.; Shafaei, H. The efficiency of PCL/HAp electrospun nanofibers in bone regeneration: A review. J. Med. Eng. Technol. 2021, 45, 1-21. [CrossRef] [PubMed]

242. Malysheva, K.; Kwaśniak, K.; Gnilitskyi, I.; Barylyak, A.; Zinchenko, V.; Fahmi, A.; Korchynskyi, O.; Bobitski, Y. Functionalization of Polycaprolactone Electrospun Osteoplastic Scaffolds with Fluorapatite and Hydroxyapatite Nanoparticles: Biocompatibility Comparison of Human Versus Mouse Mesenchymal Stem Cells. Materials 2021, 14, 1333. [CrossRef]

243. Dwivedi, R.; Kumar, S.; Pandey, R.; Mahajan, A.; Nandana, D.; Katti, D.S.; Mehrotra, D. Polycaprolactone as biomaterial for bone scaffolds: Review of literature. J. Oral Biol. Craniofacial Res. 2020, 10, 381-388. [CrossRef] [PubMed]

244. Liu, J.; Zou, Q.; Wang, C.; Lin, M.; Li, Y.; Zhang, R.; Li, Y. Electrospinning and 3D printed hybrid bi-layer scaffold for guided bone regeneration. Mater. Des. 2021, 210, 110047. [CrossRef]

245. Hashemi, S.F.; Mehrabi, M.; Ehterami, A.; Gharravi, A.M.; Bitaraf, F.S.; Salehi, M. In-vitro and in-vivo studies of PLA/PCL/gelatin composite scaffold containing ascorbic acid for bone regeneration. J. Drug Deliv. Sci. Technol. 2021, 61, 102077. [CrossRef]

246. Semitela, A.; Girao, A.F.; Fernandes, C.; Ramalho, G.; Bdikin, I.; Completo, A.; Marques, P.A. Electrospinning of bioactive polycaprolactone-gelatin nanofibres with increased pore size for cartilage tissue engineering applications. J. Biomater. Appl. 2020, 35, 459-470. [CrossRef]

247. Rofiqoh, N.; Putri, E.; Wang, X.; Chen, Y.; Li, X.; Kawazoe, N.; Chen, G. Preparation of PLGA-collagen hybrid scaffolds with controlled pore structures for cartilage tissue engineering. Prog. Nat. Sci. Mater. Int. 2020, 30, 642-650. [CrossRef]

248. Kadir, N.D.; Yang, Z.; Hassan, A.; Denslin, V.; Lee, E.H. Electrospun fibers enhanced the paracrine signaling of mesenchymal stem cells for cartilage regeneration. Stem Cell Res. Ther. 2021, 12, 1-17. [CrossRef] [PubMed]

249. Chen, S.; Chen, W.; Chen, Y.; Mo, X.; Fan, C. Chondroitin sulfate modified 3D porous electrospun nano fi ber scaffolds promote cartilage regeneration. Mater. Sci. Eng. C 2021, 118, 111312. [CrossRef]

250. Chen, Y.; Xu, W.; Shafiq, M.; Tang, J.; Hao, J.; Xie, X.; Yuan, Z.; Xiao, X.; Liu, Y.; Mo, X. Three-dimensional porous gas-foamed electrospun nanofiber scaffold for cartilage regeneration. J. Colloid Interface Sci. 2021, 603, 94-109. [CrossRef]

251. Eom, S.; Park, S.M.; Hwang, D.G.; Kim, H.W.; Jang, J.; Kim, D.S. Fabrication of an align-random distinct, heterogeneous nanofiber mat endowed with bifunctional properties for engineered 3D cardiac anisotropy. Compos. Part B Eng. 2021, 226, 109336. [CrossRef]

252. Mahmoodi, M.; Haghighi, V.; Mirhaj, M.; Tavafoghi, M.; Shams, F.; Darabi, A. Highly osteogenic and mechanically strong nanofibrous scaffolds based on functionalized multi-walled carbon nanotubes-reinforced electrospun keratin/poly( $\varepsilon$-caprolactone). Mater. Today Commun. 2021, 27, 102401. [CrossRef]

253. Haldar, S.; Sharma, A.; Gupta, S.; Chauhan, S.; Roy, P.; Lahiri, D. Bioengineered smart trilayer skin tissue substitute for efficient deep wound healing. Mater. Sci. Eng. C 2019, 105, 110140. [CrossRef] [PubMed]

254. Ranjbarvan, P.; Golchin, A.; Azari, A.; Niknam, Z. The bilayer skin substitute based on human adipose-derived mesenchymal stem cells and neonate keratinocytes on the 3D nanofibrous PCL-platelet gel scaffold. Polym. Bull. 2021, 1-18. [CrossRef]

255. Choi, W.S.; Kim, J.H.; Ahn, C.B.; Lee, J.H.; Kim, Y.J.; Son, K.H.; Lee, J.W. Development of a Multi-Layer Skin Substitute Using Human Hair Keratinic Extract-Based Hybrid 3D Printing. Polymers 2021, 13, 2584. [CrossRef] 
256. Hivechi, A.; Milan, P.B.; Modabberi, K.; Amoupour, M.; Ebrahimzadeh, K.; Gholipour, A.R.; Sedighi, F.; Amini, N.; Bahrami, S.H.; Rezapour, A.; et al. Synthesis and Characterization of Exopolysaccharide Encapsulated PCL/Gelatin Skin Substitute for Full-Thickness Wound Regeneration. Polymers 2021, 13, 854. [CrossRef] [PubMed]

257. Karmakar, G.; Dey, K.; Ghosh, P.; Sharma, B.K.; Erhan, S.Z. A Short Review on Polymeric Biomaterials as Additives for Lubricants. Polymers 2021, 13, 1333. [CrossRef]

258. Antiscalants/Scale Inhibitors Market by Type (Phosphonates, Carboxylates/Acrylic, Sulfonates, and Others), Application (Power and Construction, Mining, Oil and Gas, Water and Wastewater Treatment, Food and Beverages, and Others) and by RegionGlobal Forecast to 2020. Available online: https:/ / www.marketsandmarkets.com/Market-Reports/scale-inhibitors-market-482. html (accessed on 1 December 2021).

259. Mpelwa, M.; Tang, S.F. State of the art of synthetic threshold scale inhibitors for mineral scaling in the petroleum industry: A review. Pet. Sci. 2019, 16, 830-849. [CrossRef]

260. Al-Hamzah, A.A.; Fellows, C.M. A comparative study of novel scale inhibitors with commercial scale inhibitors used in seawater desalination. Desalination 2015, 359, 22-25. [CrossRef]

261. Chen, J.Q.; Liu, T.R.; Sun, M.M.; Zhao, Y.Z.; Ge, H.H. Inhibition of Poly(ethylenediaminetetraacetic acid-diethanolamine) on Deposition of Calcium Sulfate Crystal in Simulated Industrial Water. Crystals 2020, 10, 544. [CrossRef]

262. Moya, S.M.; Botella, N.B. Review of Techniques to Reduce and Prevent Carbonate Scale. Prospecting in Water Treatment by Magnetism and Electromagnetism. Water 2021, 13, 2365. [CrossRef]

263. Hou, L.; Kumar, D.; Yoo, C.G.; Gitsov, I.; Majumder, E.L.W. Conversion and removal strategies for microplastics in wastewater treatment plants and landfills. Chem. Eng. J. 2021, 406, 126715. [CrossRef]

264. Zeino, A.; Albakri, M.; Khaled, M.; Zarzour, M. Comparative study of the synergistic effect of ATMP and DTPMPA on CaSO 4 scale inhibition and evaluation of induction time effect. J. Water Process. Eng. 2018, 21, 1-8. [CrossRef]

265. Tang, Y.; Yang, W.; Yin, X.; Liu, Y.; Yin, P.; Wang, J. Investigation of $\mathrm{CaCO}_{3}$ scale inhibition by PAA, ATMP and PAPEMP. Desalination 2008, 228, 55-60. [CrossRef]

266. Li, C.; Zhang, C.; Zhang, W. The inhibition effect mechanisms of four scale inhibitors on the formation and crystal growth of $\mathrm{CaCO}_{3}$ in solution. Sci. Rep. 2019, 9, 13366. [CrossRef] [PubMed]

267. Sun, Y.; Yin, X.; Chen, Z.; Yang, W.; Chen, Y.; Liu, Y.; Zuo, Y.; Li, L. Use of polyaminoamide dendrimers starting from different core-initial molecules for inhibition of silica scale: Experiment and theory. Colloids Surf. A Physicochem. Eng. Asp. 2021, 613, 126095. [CrossRef]

268. Blanco, M.; Monteserín, C.; Angulo, A.; Pérez-Márquez, A.; Maudes, J.; Murillo, N.; Aranzabe, E.; Ruiz-Rubio, L.; Vilas, J.L. $\mathrm{TiO}_{2}$-Doped Electrospun Nanofibrous Membrane for Photocatalytic Water Treatment. Polymers 2019, 11, 747. [CrossRef] [PubMed]

269. Gontarek-Castro, E.; Rybarczyk, M.K.; Castro-Muñoz, R.; Morales-Jiménez, M.; Barragán-Huerta, B.; Lieder, M. Characterization of PVDF/Graphene Nanocomposite Membranes for Water Desalination with Enhanced Antifungal Activity. Water 2021, $13,1279$. [CrossRef]

270. Babaei-Ghazvini, A.; Acharya, B.; Korber, D.R. Antimicrobial Biodegradable Food Packaging Based on Chitosan and Metal/MetalOxide Bio-Nanocomposites: A Review. Polymers 2021, 13, 2790. [CrossRef] [PubMed]

271. Membrane Filtration Market by Type (RO, UF, MF, NF), Application (Water, Dairy, Drinks \& Concentrates, Wine \& Beer), Module Design (Spiral, Tubular, Plate \& Frame), Membrane Material (Polymeric \& Ceramic), and Region-Global Forecast to 2025. Available online: https: / www.marketwatch.com/press-release/membrane-filtration-market-size-is-expected-to-reach-usd244-billion-by-2026-2021-01-28 (accessed on 1 December 2021).

272. Rabajczyk, A.; Zielecka, M.; Cygańczuk, K.; Pastuszka, Ł.; Jurecki, L. Nanometals-Containing Polymeric Membranes for Purification Processes. Materials 2021, 14, 513. [CrossRef]

273. Mozia, S.; Grylewicz, A.; Zgrzebnicki, M.; Darowna, D.; Czyżewski, A. Investigations on the Properties and Performance of Mixed-Matrix Polyethersulfone Membranes Modified with Halloysite Nanotubes. Polymers 2019, 11, 671. [CrossRef]

274. Kim, H.; Shim, I.; Zhan, M. Chemical Enhanced Backwashing for Controlling Organic Fouling in Drinking Water Treatment Using a Novel Hollow-Fiber Polyacrylonitrile Nanofiltration Membrane. Appl. Sci. 2021, 11, 6764. [CrossRef]

275. Liu, L.-F.; Gu, X.-L.; Xie, X.; Li, R.-H.; Yu, C.-Y.; Song, X.-X.; Gao, C.-J. Modification of PSf/SPSf Blended Porous Support for Improving the Reverse Osmosis Performance of Aromatic Polyamide Thin Film Composite Membranes. Polymers 2018, 10, 686. [CrossRef] [PubMed]

276. Yang, Z.; Zhou, Y.; Feng, Z.; Rui, X.; Zhang, T.; Zhang, Z. A Review on Reverse Osmosis and Nanofiltration Membranes for Water Purification. Polymers 2019, 11, 1252. [CrossRef]

277. Yu, J.; Gu, K.; Yang, B.; Wang, K.; Zhou, Y.; Gao, C. The Permeability and Selectivity of the Polyamide Reverse Osmosis Membrane were Significantly Enhanced by $\mathrm{PhSiCl}_{3}$. Membranes 2021, 11, 142. [CrossRef]

278. Yahagi, T.; Degawa, M.; Seino, Y.; Matsushima, T.; Nagao, M.; Sugimura, T.; Hashimoto, Y. Mutagenicity of carcinogenic azo dyes and their derivatives. Cancer Lett. 1975, 1, 91-96. [CrossRef]

279. Golka, K.; Kopps, S.; Myslak, Z.W. Carcinogenicity of azo colorants: Influence of solubility and bioavailability. Toxicol. Lett. 2004, 151, 203-210. [CrossRef]

280. Pagga, U.; Brown, D. The degradation of dyestuffs: Part II Behaviour of dyestuffs in aerobic biodegradation tests. Chemosphere 1986, 15, 479-491. [CrossRef] 
281. Ishak, S.A.; Murshed, M.F.; Akil, H.M.; Ismail, N.; Rasib, S.Z.M.; Al-Gheethi, A.A.S. The Application of Modified Natural Polymers in Toxicant Dye Compounds Wastewater: A Review. Water 2020, 12, 2032. [CrossRef]

282. Bahrpaima, K.; Fatehi, P. Preparation and Coagulation Performance of Carboxypropylated and Carboxypentylated Lignosulfonates for Dye Removal. Biomolecules 2019, 9, 383. [CrossRef]

283. El-Shamy, A.G. An efficient removal of methylene blue dye by adsorption onto carbon dot @ zinc peroxide embedded poly vinyl alcohol (PVA/CZnO2) nano-composite: A novel Reusable adsorbent. Polymer 2020, 202, 122565. [CrossRef]

284. Mohy Eldin, M.S.; Aly, K.M.; Khan, Z.A.; Meky, A.E.; Saleh, T.S.; Elbogamy, A.S. Development of novel acid-base ions exchanger for basic dye removal: Phosphoric acid doped pyrazole-g-polyglycidyl methacrylate. Desalination Water Treat. 2016, 57, 2404724055. [CrossRef]

285. Moghaddam, R.H.; Shabani, A.M.H.; Dadfarnia, S. Synthesis of new hydrogels based on pectin by electron beam irradiation with and without surface modification for methylene blue removal. J. Environ. Chem. Eng. 2019, 7, 102919. [CrossRef]

286. Mokhtari, N.; Afshari, M.; Dinari, M. Synthesis and characterization of a novel fluorene-based covalent triazine framework as a chemical adsorbent for highly efficient dye removal. Polymer 2020, 195, 122430. [CrossRef]

287. Khan, A.; Momina, M.; Siddiqui, M.R.; Otero, M.; Alshareef, S.A.; Rafatullah, M. Removal of Rhodamine B from Water Using a Solvent Impregnated Polymeric Dowex 5WX8 Resin: Statistical Optimization and Batch Adsorption Studies. Polymers 2020, 12, 500. [CrossRef]

288. Saleh, T.A. Protocols for synthesis of nanomaterials, polymers, and green materials as adsorbents for water treatment technologies. Environ. Technol. Innov. 2021, 24, 101821. [CrossRef]

289. Mok, C.F.; Ching, Y.C.; Muhamad, F.; Osman, N.A.A.; Dai Hai, N.; Hassan, C.R.C. Adsorption of Dyes Using Poly(vinyl alcohol) (PVA) and PVA-Based Polymer Composite Adsorbents: A Review. J. Polym. Environ. 2020, 28, 775-793. [CrossRef]

290. Kong, Y.; Zhuang, Y.; Han, Z.; Yu, J.; Shi, B.; Han, K.; Hao, H. Dye removal by eco-friendly physically cross-linked double network polymer hydrogel beads and their functionalized composites. J. Environ. Sci. 2019, 78, 81-91. [CrossRef]

291. Abid, Z.; Hakiki, A.; Boukoussa, B.; Launay, F.; Hamaizi, H.; Bengueddach, A.; Hamacha, R. Preparation of highly hydrophilic PVA/SBA-15 composite materials and their adsorption behavior toward cationic dye: Effect of PVA content. J. Mater. Sci. 2019, 54, 7679-7691. [CrossRef]

292. Sanchez, L.M.; Ollier, R.P.; Alvarez, V.A. Sorption behavior of polyvinyl alcohol/bentonite hydrogels for dyes removal. J. Polym. Res. 2019, 26, 142. [CrossRef]

293. Sabarish, R.; Unnikrishnan, G. Polyvinyl alcohol/carboxymethyl cellulose/ZSM-5 zeolite biocomposite membranes for dye adsorption applications. Carbohydr. Polym. 2018, 199, 129-140. [CrossRef] [PubMed]

294. Zare, E.N.; Lakouraj, M.M.; Kasirian, N. Development of effective nano-biosorbent based on poly-m-phenylenediamine grafted dextrin for removal of $\mathrm{Pb}(\mathrm{II})$ and methylene blue from water. Carbohydr. Polym. 2018, 201, 539-548. [CrossRef]

295. Stejskal, J. Interaction of conducting polymers, polyaniline and polypyrrole, with organic dyes: Polymer morphology control, dye adsorption and photocatalytic decomposition. Chem. Pap. 2020, 74, 1-5. [CrossRef]

296. Zeng, S.; Yang, J.; Qiu, X.Y.; Liang, Z.Y.; Zhang, Y.M. Magnetically recyclable MnFe2O4/polyaniline composite with enhanced visible light photocatalytic activity for rhodamine B degradation. J. Ceram. Soc. Jpn. 2016, 124, 1152-1156. [CrossRef]

297. Cova, T.F.; Murtinho, D.; Aguado, R.; Pais, A.A.C.C.; Valente, A.J.M. Cyclodextrin Polymers and Cyclodextrin-Containing Polysaccharides for Water Remediation. Polysaccharides 2021, 2, 16-38. [CrossRef]

298. Crini, G. Kinetic and equilibrium studies on the removal of cationic dyes from aqueous solution by adsorption onto a cyclodextrin polymer. Dye. Pigment. 2008, 77, 415-426. [CrossRef]

299. Wang, J.; Cheng, G.; Lu, J.; Chen, H.; Zhou, Y. PDA-cross-linked beta-cyclodextrin: A novel adsorbent for the removal of BPA and cationic dyes. Water Sci. Technol. 2020, 81, 2337-2350. [CrossRef] [PubMed]

300. Ge, F.; Li, M.M.; Ye, H.; Zhao, B.X. Effective removal of heavy metal ions $\mathrm{Cd} 2^{+}, \mathrm{Zn} 2^{+}, \mathrm{Pb}^{+}$, Cu2 ${ }^{+}$from aqueous solution by polymer-modified magnetic nanoparticles. J. Hazard. Mater. 2012, 211, 366-372. [CrossRef]

301. Ge, F.; Ye, H.; Li, M.M.; Zhao, B.X. Efficient removal of cationic dyes from aqueous solution by polymer-modified magnetic nanoparticles. Chem. Eng. J. 2012, 198, 11-17. [CrossRef]

302. Liu, A.; Wang, C.C.; Wang, C.Z.; Fu, H.F.; Peng, W.; Cao, Y.L.; Chu, H.Y.; Du, A.F. Selective adsorption activities toward organic dyes and antibacterial performance of silver-based coordination polymers. J. Colloid Interface Sci. 2018, 512, 730-739. [CrossRef]

303. Yeamin, M.B.; Islam, M.M.; Chowdhury, A.N.; Awual, M.R. Efficient encapsulation of toxic dyes from wastewater using several biodegradable natural polymers and their composites. J. Clean. Prod. 2021, 291, 125920. [CrossRef]

304. Ramazani, A.; Oveisi, M.; Sheikhi, M.; Gouranlou, F. Natural Polymers as environmental Friendly Adsorbents for Organic Pollutants such as Dyes Removal from Colored Wastewater. Curr. Org. Chem. 2018, 22, 1297-1306. [CrossRef]

305. Yin, X.; Zhang, N.; Du, M.; Zhu, H.; Ke, T. Preparation of bio-absorbents by modifying licorice residue via chemical methods and removal of copper ions from wastewater. Water Sci. Technol. 2021. [CrossRef]

306. Vidovix, T.B.; Quesada, H.B.; Bergamasco, R.; Vieira, M.F.; Vieira, A.M.S. Adsorption of Safranin-O dye by copper oxide nanoparticles synthesized from Punica granatum leaf extract. Environ. Technol. 2021, 2021, 1-17. [CrossRef]

307. Sebeia, N.; Jabli, M.; Ghith, A.; El-Ghoul, Y.; Alminderej, F.M. Production of cellulose from Aegagropila Linnaei macro-algae: Chemical modification, characterization and application for the bio-sorption of cationic and anionic dyes from water. Int. J. Biol. Macromol. 2019, 135, 152-162. [CrossRef] 
308. Sebeia, N.; Jabli, M.; Ghith, A.; El-Ghoul, Y.; Alminderej, F.M. Populus tremula, Nerium oleander and Pergularia tomentosa seed fibers as sources of cellulose and lignin for the bio-sorption of methylene blue. Int. J. Biol. Macromol. 2019, 121, 655-665. [CrossRef]

309. Ammar, C.; El-Ghoul, Y.; Jabli, M. Characterization and valuable use of Calotropis gigantea seedpods as a biosorbent of methylene blue. Int. J. Phytoremediation 2021, 23, 1085-1094. [CrossRef]

310. Kayan, G.Ö.; Kayan, A. Composite of Natural Polymers and Their Adsorbent Properties on the Dyes and Heavy Metal Ions. J. Polym. Environ. 2021. [CrossRef]

311. Almutairi, F.M.; El-Ghoul, Y.; Jabli, M. Extraction of Cellulose Polymeric Material from Populus tremula Fibers: Characterization and Application to the Adsorption of Methylene Blue and Crystal Violet. Polymers 2021, 13, 3334. [CrossRef] [PubMed]

312. Sajjadi, M.; Ahmadpoor, F.; Nasrollahzadeh, M.; Ghafuri, H. Lignin-derived (nano) materials for environmental pollution remediation: Current challenges and future perspectives. Int. J. Biol. Macromol. 2021, 178, 394-423. [CrossRef]

313. Yadav, S.; Asthana, A.; Chakraborty, R.; Jain, B.; Singh, A.K.; Carabineiro, S.A.C.; Susan, M.A.B.H. Cationic Dye Removal Using Novel Magnetic/Activated Charcoal/ $\beta$-Cyclodextrin/Alginate Polymer Nanocomposite. Nanomaterials 2020, 10, 170. [CrossRef]

314. Bhangi, B.K.; Ray, S.K. Nano silver chloride and alginate incorporated composite copolymer adsorbent for adsorption of a synthetic dye from water in a fixed bed column and its photocatalytic reduction. Int. J. Biol. Macromol. 2020, 144, 801-812. [CrossRef]

315. Agougui, H.; Sebeia, N.; Jabli, M.; El-Ghoul, Y.; Boughzala, B. Synthesis of hydroxyapatite-sodium metasilicate via double decomposition method: Characterization and application to the removal of methylene blue. Inorg. Chem. Commun. 2021, 133, 108986. [CrossRef]

316. Samadder, R.; Akter, N.; Roy, A.C.; Uddin, M.M.; Hossen, M.J.; Azam, M.S. Magnetic nanocomposite based on polyacrylic acid and carboxylated cellulose nanocrystal for the removal of cationic dye. RSC Adv. 2020, 10, 11945-11956. [CrossRef]

317. Sankararamakrishnan, N.; Singh, N.; Srivastava, I. Hierarchical nano Fe(0)@FeS doped cellulose nanofibres derived from agrowaste-potential bionanocomposite for treatment of organic dyes. Int. J. Biol. Macromol. 2020, 151, 713-722. [CrossRef]

318. Yu, Z.; Hu, C.; Dichiara, A.B.; Jiang, W.; Gu, J. Cellulose nanofibril/carbon nanomaterial hybrid aerogels for adsorption removal of cationic and anionic organic dyes. Nanomaterials 2020, 10, 169. [CrossRef]

319. Eltaweil, A.S.; Elgarhy, G.S.; El-Subruiti, G.M.; Omer, A.M. Carboxymethyl cellulose/carboxylated graphene oxide composite microbeads for efficient adsorption of cationic methylene blue dye. Int. J. Biol. Macromol. 2020, 154, 307-318. [CrossRef]

320. Sayğılı, G.A.; Güzel, F. Chemical Modification of a Cellulose-Based Material to Improve Its Adsorption Capacity for Anionic Dyes. J. Dispers. Sci. Technol. 2017, 38, 381-392. [CrossRef]

321. Salimpour, S.A.; Malek, R.M.A.; Mazaheri, F. Dye adsorption of cotton fabric grafted with PPI dendrimers: Isotherm and kinetic studies. J. Environ. Manag. 2015, 163, 53-61. [CrossRef]

322. Obradith, C.; Jency, D.R.; Andrés, M. Adsorption of Common Laboratory Dyes Using Natural Fibers from Luffa cylindrica. J. Chem. Educ. 2018, 95, 2233-2237. [CrossRef]

323. Grabi, H.; Derridj, F.; Lemlikchi, W.; Guénin, E. Studies of the potential of a native natural biosorbent for the elimination of an anionic textile dye Cibacron Blue in aqueous solution. Sci. Rep. 2021, 11, 9705. [CrossRef]

324. Rigueto, C.V.T.; Piccin, J.S.; Dettmer, A.; Rosseto, M.; Dotto, G.L.; de Oliveira Schmitz, A.P.; Perondi, D.; de Freitas, T.S.M.; Loss, R.A.; Geraldi, C.A.Q. Water hyacinth (Eichhornia crassipes) roots, an amazon natural waste, as an alternative biosorbent to uptake a reactive textile dye from aqueous solutions. Ecol. Eng. 2020, 150, 105817. [CrossRef]

325. Boumaza, S.; Yenounne, A.; Hachi, W.; Kaouah, F.; Bouhamidi, Y.; Trari, M. Application of Typha angustifolia (L.) Dead Leaves Waste as Biomaterial for the Removal of Cationic Dye from Aqueous Solution. Int. J. Environ. Res. 2018, 12, 561-573. [CrossRef]

326. Jabli, M.; Gamha, E.; Sebeia, N.; Hamdaoui, M. Almond shell waste (Prunus dulcis): Functionalization with [dimethy-diallylammonium-chloride-diallylamin-co-polymer] and chitosan polymer and its investigation in dye adsorption. J. Mol. Liq. 2017, 240, 35-44. [CrossRef]

327. Khodabandehloo, A.; Shayesteh, H.; Rahbar-Kelishami, A. Methylene blue removal using Salix babylonica (Weeping willow) leaves powder as a low-cost biosorbent in batch mode: Kinetic, equilibrium, and thermodynamic studies. J. Mol. Liq. 2017, 244, 540-548. [CrossRef]

328. Abdelkarim, S.; Mohammed, H.; Nouredine, B. Sorption of Methylene Blue Dye from Aqueous Solution Using an Agricultural Waste. Trends Green Chem. 2017, 3, 1-7. [CrossRef]

329. Ammar, C.; Alminderej, F.M.; EL-Ghoul, Y.; Jabli, M.; Shafiquzzaman, M. Preparation and Characterization of a New Polymeric Multi-Layered Material Based K-Carrageenan and Alginate for Efficient Bio-Sorption of Methylene Blue Dye. Polymers 2021, 13, 411. [CrossRef]

330. Nascimento, G.E.; Campos, N.F.; Silva, J.J.; Barbosa, C.M.B.M.; Duarte, M.M.M.B. Adsorption of anionic dyes from an aqueous solution by banana peel and green coconut mesocarp. Desalination Water Treat. 2016, 57, 14093-14108. [CrossRef]

331. N'diaye, A.D.; Ali, Y.A.E.H.; Abdallahi, O.E.M.; Bollahi, M.A.; Stitou, M.; Kankou, M.; Fahmi, D. Sorption of Malachite Green from Aqueous Solution using Typha australis Leaves as a Low Cost Sorbent. J. Environ. Treat. Tech. 2020, 8, $1023-1028$.

332. Salazar-Rabago, J.J.; Leyva-Ramos, R.; Rivera-Utrilla, J.; Ocampo-Perez, R.; Cerino-Cordova, F.J. Biosorption mechanism of Methylene Blue from aqueous solution onto white pine (Pinus durangensis) sawdust: Effect of operating conditions. Sustain. Environ. Res. 2016, 27, 32-40. [CrossRef] 
333. Rahmat, N.A.; Ali, A.A.; Salmiati, H.N.; Muhamad, M.S.; Kristanti, R.A.; Hadibarata, T. Removal of Remazol Brilliant Blue R from Aqueous Solution by Adsorption Using Pineapple Leaf Powder and Lime Peel Powder. Water Air Soil Pollut. 2016, 227, 105. [CrossRef]

334. Lazim, Z.M.; Mazuin, E.; Hadibarata, T.; Yusop, Z. The removal of methylene blue and Remazol Brilliant Blue R dyes by using orange peel and spent tea leaves. J. Teknol. 2015, 74, 129-135. [CrossRef]

335. Mafra, M.R.; Igarashi-Mafra, L.; Zuim, D.R.; Vasques, E.C.; Ferreira, M.A. Adsorption of Remazol Brilliant Blue on an orange peel adsorbent. Braz. J. Chem. Eng. 2013, 30, 657-665. [CrossRef]

336. Pelosi, B.T.; Lima, L.K.S.; Vieira, M.G.A. Removal of the synthetic dye Remazol Brilliant Blue R from textile industry wastewaters by biosorption on the macrophyte Salvinia natans. Braz. J. Chem. Eng. 2014, 31, 1035-1045. [CrossRef]

337. Jawad, A.H.; Razuan, R.; Appaturi, J.N.; Wilson, L.D. Adsorption and mechanism study for methylene blue dye removal with carbonized watermelon (Citrullus lanatus) rind prepared via one-step liquid phase $\mathrm{H}_{2} \mathrm{SO}_{4}$ activation. Surf. Interfaces 2019, 16, 76-84. [CrossRef]

338. Lakshmipathy, R.; Reddy, N.A.; Sarada, N.C. Optimization of brilliant green biosorption by native and acid-activated watermelon rind as low-cost adsorbent. Desalination Water Treat. 2015, 54, 235-244. [CrossRef]

339. Ahmad, M.A.; Ahmad, N.; Bello, O.S. Removal of remazol brilliant blue reactive dye from aqueous solutions using watermelon rinds as adsorbent. J. Dispers. Sci. Technol. 2015, 36, 845-858. [CrossRef]

340. Ahmad, M.A.; Ahmad, N.; Bello, O.S. Statistical optimization of adsorption process for removal of synthetic dye using watermelon rinds. Model. Earth Syst. Environ. 2017, 3, 25. [CrossRef]

341. Masoudian, N.; Rajabi, M.; Ghaedi, M. Titanium oxide nanoparticles loaded onto activated carbon prepared from bio-waste watermelon rind for the efficient ultrasonic-assisted adsorption of congo red and phenol red dyes from wastewaters. Polyhedron 2019, 173, 114105. [CrossRef]

342. Chigbundu, E.C.; Adebowale, K.O. Equilibrium and fractal-like kinetic studies of the sorption of acid and basic dyes onto watermelon shell (Citrullus vulgaris). Cellulose 2017, 24, 4701-4714. [CrossRef]

343. Silva, F.; Nascimento, L.; Brito, M.; da Silva, K.; Paschoal, W.; Fujiyama, R. Biosorption of Methylene Blue Dye Using Natural Biosorbents Made from Weeds. Materials 2019, 12, 2486. [CrossRef]

344. Rangabhashiyam, S.; Lata, S.; Balasubramanian, P. Biosorption characteristics of methylene blue and malachite green from simulated wastewater onto Carica papaya wood biosorbent. Surf. Interfaces 2018, 10, 197-215. [CrossRef]

345. Honorato, A.C.; Machado, J.M.; Celante, G.; Borges, W.G.P.; Dragunski, D.C.; Caetano, J. Biosorption of methylene blue using agroindustrial residues. Rev. Bras. Eng. Agric. Amb. 2015, 19, 705-710. [CrossRef]

346. Alfredo, A.P.C.; Gonçalves, G.C.; Lobo, V.S.; Montanher, S.F. Adsorção de azul de metileno em casca de batata utilizando sistemas em batelada e coluna de leito fixo. Rev. Virtual Quim. 2015, 7, 1909-1920. [CrossRef]

347. Miraboutalebi, S.M.; Nikouzad, S.K.; Peydayesh, M.; Allahgholi, N.; Vafajoo, L.; McKay, G. Methylene blue adsorption via maize silk powder: Kinetic, equilibrium, thermodynamic studies and residual error analysis. Process. Saf. Environ. Prot. 2017, 106, 191-202. [CrossRef]

348. Tang, Y.F.; Hu, T.; Zeng, Y.D.; Zhou, Q.; Peng, Y.Z. Effective adsorption of cationic dyes by lignin sulfonate polymer based on simple emulsion polymerization: Isotherm and kinetic studies. RSC Adv. 2015, 5, 3757-3766. [CrossRef]

349. Tang, Y.; Zeng, Y.; Hu, T.; Zhou, Q.; Peng, Y. Preparation of lignin sulfonate-based mesoporous materials for adsorbing malachite green from aqueous solution. J. Environ. Chem. Eng. 2016, 4, 2900-2910. [CrossRef]

350. Afshariani, F.; Roosta, A. Experimental study and mathematical modeling of biosorption of methylene blue from aqueous solution in a packed bed of microalgae Scenedesmus. J. Clean. Prod. 2019, 225, 133-142. [CrossRef]

351. Heidarinejad, Z.; Rahmanian, O.; Fazlzadeh, M.; Heidari, M. Enhancement of methylene blue adsorption onto activated carbon prepared from Date Press Cake by low frequency ultrasound. J. Mol. Liq. 2018, 264, 591-599. [CrossRef]

352. Islam, M.A.; Sabar, S.; Benhouria, A.; Khanday, W.A.; Asif, M.; Hameed, B.H. Nanoporous activated carbon prepared from karanj (Pongamia pinnata) fruit hulls for methylene blue adsorption. J. Taiwan Inst. Chem. Eng. 2017, 74, 96-104. [CrossRef]

353. Islam, M.A.; Ahmed, M.J.; Khanday, W.A.; Asif, M.; Hameed, B.H. Mesoporous activated carbon prepared from NaOH activation of rattan (Lacosperma secundiflorum) hydrochar for methylene blue removal. Ecotoxicol. Environ. Saf. 2017, 138, 279-285. [CrossRef]

354. Kumar, A.; Jena, H.M. Removal of methylene blue and phenol onto prepared activated carbon from Fox nutshell by chemical activation in batch and fixed-bed column. J. Clean. Prod. 2016, 137, 1246-1259. [CrossRef]

355. Jawad, A.H.; Abdulhameed, A.S.; Abdallah, R.; Yaseen, Z.M. Zwitterion composite chitosan-epichlorohydrin/zeolite for adsorption of methylene blue and reactive red 120 dyes. Int. J. Biol. Macromol. 2020, 163, 756-765. [CrossRef]

356. Kong, Q.; Wang, X.; Lou, T. Preparation of millimeter-sized chitosan/carboxymethyl cellulose hollow capsule and its dye adsorption properties. Carbohydr. Polym. 2020, 244, 116481. [CrossRef] [PubMed]

357. Zheng, X.; Zheng, H.; Xiong, Z.; Zhao, R.; Liu, Y.; Zhao, C.; Zheng, C. Novel anionic polyacrylamide-modify-chitosan magnetic composite nanoparticles with excellent adsorption capacity for cationic dyes and $\mathrm{pH}$-independent adsorption capability for metal ions. Chem. Eng. J. 2020, 392, 123706. [CrossRef]

358. Jawad, A.H.; Mubarak, N.S.A.; Abdulhameed, A.S. Hybrid Crosslinked Chitosan-Epichlorohydrin/TiO2 Nanocomposite for Reactive Red 120 Dye Adsorption: Kinetic, Isotherm, Thermodynamic, and Mechanism Study. J. Polym. Environ. 2020, 28 , 624-637. [CrossRef] 
359. Chen, Y.; Long, W.; Xu, H. Efficient removal of Acid Red 18 from aqueous solution by in-situ polymerization of polypyrrolechitosan composites. J. Mol. Liq. 2019, 287, 110888. [CrossRef]

360. Jawad, A.H.; Abdulhameed, A.S.; Mastuli, M.S. Mesoporous Crosslinked Chitosan-Activated Charcoal Composite for the Removal of Thionine Cationic Dye: Comprehensive Adsorption and Mechanism Study. J. Polym. Environ. 2020, 28, 1095-1105. [CrossRef]

361. Mohammad, A.T.; Abdulhameed, A.S.; Jawad, A.H. Box-Behnken design to optimize the synthesis of new crosslinked chitosanglyoxal/TiO2 nanocomposite: Methyl orange adsorption and mechanism studies. Int. J. Biol. Macromol. 2019, 129, 98-109. [CrossRef]

362. Li, Z.; Sellaoui, L.; Dotto, G.L.; Lamine, A.B.; Bonilla-Petriciolet, A.; Hanafy, H.; Erto, A. Interpretation of the adsorption mechanism of Reactive Black 5 and Ponceau $4 \mathrm{R}$ dyes on chitosan/polyamide nanofibers via advanced statistical physics model. J. Mol. Liq. 2019, 285, 165-170. [CrossRef]

363. Zeng, M.; Wu, W.; Fang, J.; Li, S.; Zhou, Z. Fabrication of chitosan/alginate porous sponges as adsorbents for the removal of acid dyes from aqueous solution. J. Mater. Sci. 2019, 54, 9995-10008. [CrossRef]

364. Zhao, X.; Wang, X.; Lou, T. Preparation of fibrous chitosan/sodium alginate composite foams for the adsorption of cationic and anionic dyes. J. Hazard. Mater. 2020, 403, 124054. [CrossRef]

365. Wang, Q.; Ju, J.; Tan, Y.; Hao, L.; Ma, Y.; Wu, Y.; Zhang, H.; Xia, Y.; Sui, K. Controlled synthesis of sodium alginate electrospun nanofiber membranes for multi-occasion adsorption and separation of methylene blue. Carbohydr. Polym. 2019, 205, 125-134. [CrossRef]

366. Jiao, C.; Li, T.; Wang, J.; Wang, H.; Zhang, X.; Han, X.; Zhaofang, D.; Yali, S.; Yuyue, C. Efficient removal of dyes from aqueous solution by a porous sodium alginate/gelatin/graphene oxide triple-network composite aerogel. J. Polym. Environ. 2020, 28, 1492-1502. [CrossRef]

367. Ma, M.; Liu, Z.; Hui, L.; Shang, Z.; Yuan, S.; Dai, L.; Liu, P.; Liu, X.; Ni, Y. Lignin-containing cellulose nanocrystals/sodium alginate beads as highly effective adsorbents for cationic organic dyes. Int. J. Biol. Macromol. 2019, 139, 640-646. [CrossRef]

368. Georgin, J.; Franco, D.S.P.; Drumm, F.C.; Grassi, P.; Schadeck Netto, M.; Allasia, D.; Dotto, G.L. Paddle cactus (Tacinga palmadora) as potential low-cost adsorbent to treat textile effluents containing crystal violet. Chem. Eng. Commun. 2020, 207, 1368-1379. [CrossRef]

369. Pang, X.; Sellaoui, L.; Franco, D.; Dotto, G.L.; Georgin, J.; Bajahzar, A.; Belmabrouk, H.; Lamine, A.B.; Bonilla-Petriciolet, A.; Li, Z. Adsorption of crystal violet on biomasses from pecan nutshell, para chestnut husk, araucaria bark and palm cactus: Experimental study and theoretical modeling via monolayer and double layer statistical physics models. Chem. Eng. J. 2019, $378,122101$. [CrossRef]

370. Louati, I.; Fersi, M.; Hadrich, B. Prickly pear cactus cladodes powder of Opuntia ficus indica as a cost effective biosorbent for dyes removal from aqueous solutions. 3 Biotech 2018, 8, 478. [CrossRef]

371. El Maguana, Y.; Elhadiri, N.; Bouchdoug, M.; Benchanaa, M.; Jaouad, A. Activated carbon from prickly pear seed cake: Optimization of preparation conditions using experimental design and its application in dye removal. Int. J. Chem. Eng. 2019, 2019, 8621951. [CrossRef]

372. Pelaez-Cid, A.A.; Herrera-González, A.M.; Salazar-Villanueva, M.; Bautista-Hernandez, A. Elimination of textile dyes using activated carbons prepared from vegetable residues and their characterization. J. Environ. Manag. 2016, 181, 269-278. [CrossRef]

373. Kim, H.R.; Jang, J.W.; Park, J.W. Carboxymethyl chitosan-modified magnetic-cored dendrimer as an amphoteric adsorbent. J. Hazard. Mater. 2016, 317, 608-616. [CrossRef]

374. Saber-Samandari, S.; Joneidi-Yekta, H.; Mohseni, M. Adsorption of anionic and cationic dyes from aqueous solution using gelatin-based magnetic nanocomposite beads comprising carboxylic acid functionalized carbon nanotube. Chem. Eng. J. 2017, 308, 1133-1144. [CrossRef]

375. Yang, D.; Qiu, L.; Yang, Y. Efficient adsorption of methyl orange using a modified chitosan magnetic composite adsorbent. J. Chem. Eng. Data 2016, 61, 3933-3940. [CrossRef]

376. Sahraei, R.; Sekhavat-Pour, Z.; Ghaemy, M. Novel magnetic bio-sorbent hydrogel beads based on modified gum tragacanth/graphene oxide: Removal of heavy metals and dyes from water. J. Clean. Prod. 2017, 142, 2973-2984. [CrossRef]

377. Mahdavinia, G.R.; Mosallanezhad, A. Facile and green rout to prepare magnetic and chitosan-crosslinked $\mathrm{k}$-carrageenan bionanocomposites for removal of methylene blue. J. Water Process. Eng. 2016, 10, 143-155. [CrossRef]

378. Soares, S.F.; Simões, T.R.; Trindade, T.; Daniel-da-Silva, A.L. Highly efficient removal of dye from water using magnetic carrageenan/silica hybrid nano-adsorbents. Water Air Soil Pollut. 2017, 228, 87. [CrossRef]

379. Gulnaz, O.; Sahmurova, A.; Kama, S. Removal of reactive red 198 from aqueous solution by Potamogeton crispus. Chem. Eng. J. 2011, 174, 579-585. [CrossRef]

380. Demarchi, C.A.; Debrassi, A.; Buzzi, F.C.; Nedelko, N.; Ślawska-Waniewska, A.; Dłużewski, P.; Magro, J.D.; Scapinello, J.; Rodrigues, C.A. Adsorption of the dye Remazol Red 198 (RR198) by O-carboxymethylchitosan-N-lauryl $/ \gamma-\mathrm{Fe}_{2} \mathrm{O}_{3}$ magnetic nanoparticles. Arab. J. Chem. 2019, 12, 3444-3453. [CrossRef]

381. Bazrafshan, E.; Mostafapour, F.K.; Mahvi, A.H. Decolorization of reactive red 198 by adsorption onto $\mathrm{ZnCl}_{2}$ activated pistachio hull wastes. Int. J. Environ. Health Eng. 2014, 3, 38-45. [CrossRef] 
382. Malakootian, M.; Mansoorian, H.J.; Hosseini, A.; Khanjani, N. Evaluating the efficacy of alumina/carbon nanotube hybrid adsorbents in removing Azo Reactive Red 198 and Blue 19 dyes from aqueous solutions. Process. Saf. Environ. Prot. 2015, 96, 125-137. [CrossRef]

383. Tayebi, H.; Dalirandeh, Z.; Rad, A.S.; Mirabi, A. Synthesis of polyaniline/ $\mathrm{Fe}_{3} \mathrm{O}_{4}$ magnetic nanoparticles for removal of reactive red 198 from textile waste water: Kinetic, isotherm, and thermodynamic studies. Desalination Water Treat. 2016, 57, 22551-22563. [CrossRef]

384. Elkady, M.F.; Ibrahim, A.M.; El-Latif, M.M.A. Assessment of the adsorption kinetics, equilibrium and thermodynamic for the potential removal of reactive red dye using eggshell biocomposite beads. Desalination 2011, 278, 412-423. [CrossRef]

385. Alimohammadi, Z.; Younesi, H.; Bahramifar, N. Batch and column adsorption of reactive red 198 from textile industry effluent by microporous activated carbon developed from walnut shells. Waste Biomass Valorization 2016, 7, 1255-1270. [CrossRef]

386. Toprak, F.; Armagan, B.; Cakici, A. Systematic approach for the optimal process conditions of Reactive Red 198 adsorption by pistachio nut shell using Taguchi method. Desalination Water Treat. 2012, 48, 96-105. [CrossRef]

387. Haffad, H.; Zbair, M.; Anfar, Z.; Ahsaine, H.A.; Bouhlal, H.; Khallok, H. Removal of reactive red-198 dye using chitosan as an adsorbent: Optimization by Central composite design coupled with response surface methodology. Toxin Rev. 2019, 40, 225-237. [CrossRef]

388. EL-Ghoul, Y.; Ammar, C.; Alminderej, F.M.; Shafiquzzaman, M. Design and Evaluation of a New Natural Multi-Layered Biopolymeric Adsorbent System-Based Chitosan/Cellulosic Nonwoven Material for the Biosorption of Industrial Textile Effluents. Polymers 2021, 13, 322. [CrossRef]

389. Wang, Y.; Wang, H.; Peng, H.; Wang, Z.; Wu, J.; Liu, Z. Dye Adsorption from Aqueous Solution by Cellulose/chitosan Composite: Equilibrium, Kinetics, and Thermodynamics. Fibers Polym. 2018, 19, 340-349. [CrossRef]

390. Azari, A.; Noorisepehr, M.; Dehganifard, E.; Karimyan, K.; Hashemi, S.Y.; Kalhori, E.M.; Norouzi, R.; Agarwal, S.; Gupta, V.K. Experimental Design, Modeling and Mechanism of Cationic Dyes Biosorption on to Magnetic Chitosan-lutaraldehyde Composite. Int. J. Biol. Macromol. 2019, 131, 633-645. [CrossRef] [PubMed]

391. Habiba, U.; Siddique, T.A.; Talebian, S.; Lee, J.J.L.; Salleh, A.; Ang, B.C.; Afifi, A.M. Effect of Deacetylation on Property of Electrospun Chitosan/PVA Nanofibrous Membrane and Removal of Methyl Orange, Fe(III) and Cr(VI) ions. Carbohydr. Polym. 2017, 177, 32-39. [CrossRef]

392. Anitha, T.; Kumar, S.P.; Kumar, S.K. Synthesis of Nano-sized Nhitosan Blended Polyvinyl Alcohol for the Removal of Eosin Yellow Dye from Aqueous Solution. J. Water Process. Eng. 2016, 13, 127-136. [CrossRef]

393. Muinde, V.M.; Onyari, J.M.; Wamalwa, B.; Wabomba, J.N. Adsorption of Malachite Green Dye from Aqueous Solutions using Mesoporous Chitosan-zinc oxide Composite Material. Environ. Chem. Ecotoxicol. 2020, 2, 115-125. [CrossRef]

394. Insulation Coatings Market by Type (Acrylic, Polyurethane, Epoxy, Mullite, YSZ), End-Use Industry (Industrial, Building, and Construction, Aerospace, Automotive, Marine), and Region (North America, South America, Europe, APAC, MEA)—Global Forecast to 2025. Available online: https:/ / www.marketsandmarkets.com/Market-Reports/insulation-coatings-market-264842 90.html (accessed on 1 December 2021).

395. Che, K.; Lyu, P.; Wan, F.; Ma, M. Investigations on Aging Behavior and Mechanism of Polyurea Coating in Marine Atmosphere. Materials 2019, 12, 3636. [CrossRef] [PubMed]

396. Wu, G.; Wang, X.; Ji, C.; Liu, Q.; Gao, Z.; Zhang, K.; Zhao, C. Experimental and numerical simulation study on polyurea-coated fuel tank subjected to combined action of blast shock waves and fragments. Thin-Walled Struct. 2021, 169, 108436. [CrossRef]

397. Ma, L.; Dong, X.; Chen, M.; Zhu, L.; Wang, C.; Yang, F.; Dong, Y. Fabrication and Water Treatment Application of Carbon Nanotubes (CNTs)-Based Composite Membranes: A Review. Membranes 2017, 7, 16. [CrossRef]

398. García-Picazo, F.J.; Pérez-Sicairos, S.; Fimbres-Weihs, G.A.; Lin, S.W.; Salazar-Gastélum, M.I.; Trujillo-Navarrete, B. Preparation of Thin-Film Composite Nanofiltration Membranes Doped with N- and Cl-Functionalized Graphene Oxide for Water Desalination. Polymers 2021, 13, 1637. [CrossRef] [PubMed]

399. Agboola, O.; Fayomi, O.S.I.; Ayodeji, A.; Ayeni, A.O.; Alagbe, E.E.; Sanni, S.E.; Okoro, E.E.; Moropeng, L.; Sadiku, R.; Kupolati, K.W.; et al. A Review on Polymer Nanocomposites and Their Effective Applications in Membranes and Adsorbents for Water Treatment and Gas Separation. Membranes 2021, 11, 139. [CrossRef] [PubMed]

400. Amari, A.; Alzahrani, F.M.; Katubi, K.M.; Alsaiari, N.S.; Tahoon, M.A.; Rebah, F.B. Clay-Polymer Nanocomposites: Preparations and Utilization for Pollutants Removal. Materials 2021, 14, 1365. [CrossRef] 